\title{
AVALIAÇÃO DO BEM-ESTAR DE AVES POEDEIRAS EM DIFERENTES SISTEMAS DE PRODUÇÃO E CONDIÇÕES
} AMBIENTAIS, UTILIZANDO ANÁLISE DE IMAGENS

\section{JOSÉ ANTONIO DELFINO BARBOSA FILHO}

\author{
Dissertação apresentada à Escola Superior de \\ Agricultura "Luiz de Queiroz", Universidade de São \\ Paulo, para obtenção de título de Mestre em \\ Agronomia, Área de Concentração: Física do \\ Ambiente Agrícola. \\ PIRACICABA \\ Estado de São Paulo - Brasil \\ Dezembro - 2004
}




\section{AVALIAÇÃO DO BEM-ESTAR DE AVES POEDEIRAS EM DIFERENTES SISTEMAS DE PRODUÇÃO E CONDIÇÕES}

AMBIENTAIS, UTILIZANDO ANÁLISE DE IMAGENS

\section{JOSÉ ANTONIO DELFINO BARBOSA FILHO}

Engenheiro Agrícola

Orientador: Prof. Dr. IRAN JOSÉ OLIVEIRA DA SILVA

Dissertação apresentada à Escola Superior de Agricultura "Luiz de Queiroz", Universidade de São Paulo, para obtenção de título de Mestre em Agronomia, Área de Concentração: Física do Ambiente Agrícola.

PIRACICABA

Estado de São Paulo - Brasil

Dezembro - 2004 
Dados Internacionais de Catalogação na Publicação (CIP) DIVISÃO DE BIBLIOTECA E DOCUMENTAÇÃO - ESALQ/USP

Barbosa Filho, José Antonio Delfino

Avaliação do bem-estar de aves poedeiras em diferentes sistemas de produção e condições ambientais, utilizando análise de imagens / José Antonio Delfino Barbosa Filho. - - Piracicaba, 2004.

123 p. : il.

Dissertação (Mestrado) - - Escola Superior de Agricultura Luiz de Queiroz, 2004. Bibliografia.

1. Ave poedeira 2. Cama de galinheiro 3. Comportamento animal 4. Conforto animal 5. Gaiola 6. Linhagem animal 7. Ovo - Produção animal 8. Processamento animal 9. Sistema de criação animal I. Título

CDD 636.514

"Permitida a cópia total ou parcial deste documento, desde que citada a fonte - O autor" 
"Levanta o olhar de tua inteligência, usa dos olhos como homem que és, coloca-os no céu e na terra, nas belezas do firmamento, na fecundidade do solo, no vôo das aves, no nado dos peixes, na vitalidade das sementes, na ordenada sucessão dos tempos, põe os olhos nas obras, olha o que vês e eleva-te ao que não vês".

Agostinho, Santo - Sermão 126,3.

Aos meus pais e avós que tanto lutaram para a realização de mais este sonho.

OFEREÇO E DEDICO 


\section{AGRADECIMENTOS}

A Deus, pela oportunidade e saúde para alcançar mais esta meta;

À Escola Superior de Agricultura "Luiz de Queiroz", e ao curso de Pósgraduação em Física do Ambiente Agrícola pelas oportunidades oferecidas;

Ao Professor Dr. Iran José Oliveira da Silva, pela orientação e amizade durante a execução deste trabalho;

Aos Professores Dr. Antonio Augusto Domingos Coelho e Dr. Vicente José Maria Savino, pelas sugestões e apoio durante a realização deste trabalho;

Aos Professores Dr. Luiz Roberto Angelocci e Dra. Kelly Botigeli Sevegnani, pelas sugestões feitas para enriquecer este trabalho;

À Professora Dra. Sônia Maria Piedade, pelo auxílio na elaboração e execução das análises estatísticas;

Ao Professor Dr. Douglas Emygdio de Faria, pelo empréstimo dos materiais utilizados na realização das análises dos ovos.

Ao Professor Dr. Julio Marcos Melges Walder e à técnica de laboratório Clarice Matraia, do CENA/USP, pela realização das análises de colorimetria; 
Aos amigos Marco Aurélio N. da Silva, Flávio Henrique A. Silva, Caio José Mortari da Silva, Anrelita P. Martins e Edival Correr, pela grande contribuição em todas as etapas deste trabalho.

À amiga Márcia Nalesso C. Harder pela colaboração nas análises de colorimetria.

À colega de trabalho Sulivan P. Alves e aos estagiários Luis Briquezi e Jéferson Bernard, pela ajuda nas prévias desta pesquisa;

Aos colegas do Núcleo de Pesquisa em Ambiência, pela amizade e apoio direto e indireto na realização deste trabalho.

Aos meus irmãos João Paulo, Ana Amélia e Ana Beatriz, pela amizade e confiança.

Aos amigos Emerson, Ademar, Lucas e Heiko, pelo apoio e ajuda indispensáveis durante todo este tempo.

À Coordenação de Aperfeiçoamento de Pessoal de Nível Superior - CAPES, pela concessão da bolsa de estudos. 
SUMÁRIO

Página

LISTA DE FIGURAS …............................................................................ ix

LISTA DE TABELAS .......................................................................

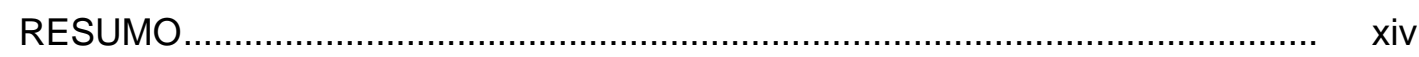

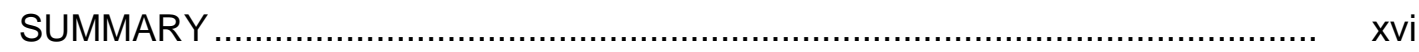

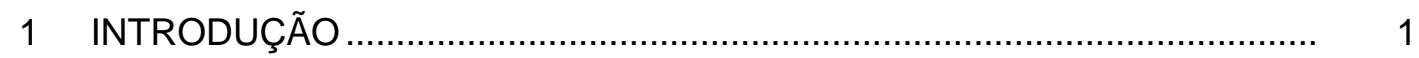

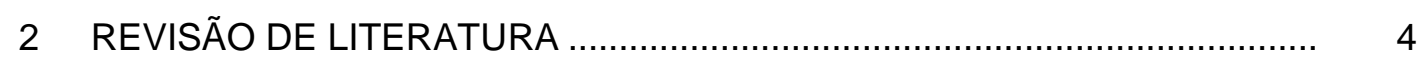

2.1 Ambiência para aves de postura ................................................................. 4

2.2 Respostas fisiológicas .......................................................................... 6

2.3 Qualidade dos ovos ................................................................................. 8

2.4 Comportamento avícola............................................................................. 9

2.5 Respostas comportamentais .................................................................... 11

2.6 Postura em cama e ninho ............................................................................. 12

2.7 Avicultura de precisão..................................................................... 14

3 MATERIAL E MÉTODOS …..................................................................... 17

3.1 Local de desenvolvimento da pesquisa .................................................... 17

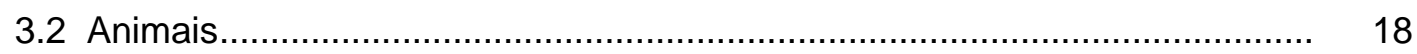

3.3 Fotoperíodo ...................................................................... 19

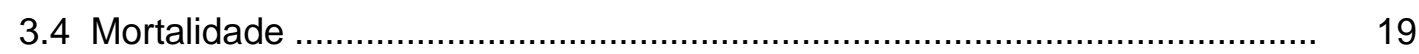

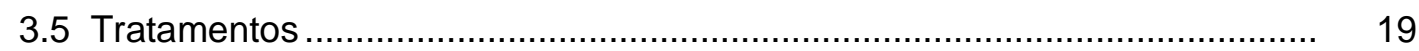

3.5.1 Exposição das aves ao ambiente controlado ........................................... 19

3.5.2 Sistemas de criação ...................................................................... 20

3.5.3 Caracterização dos sistemas de criação ................................................ 20

3.6 Parâmetros avaliados ............................................................................. 22

3.6.1Parâmetros climáticos ......................................................................... 22

3.6.2 Indices de conforto térmico ...................................................................... 23 
3.6.2.1 Indece de temperatura e umidade (THI) .............................................. 23

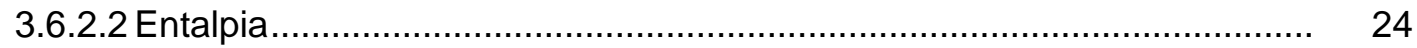

3.6.3 Parâmetros fisiológicos .................................................................. 24

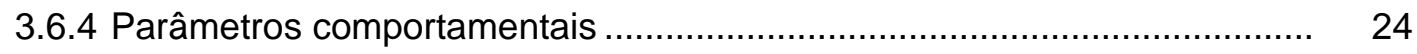

3.6.5 Ssitema de marcação das aves ........................................................... 27

3.6.6 Consumo de água e ração ................................................................... 28

3.6.7 Níveis de amônia ......................................................................... 28

3.7 Parâmetros de qualiade dos ovos ........................................................... 29

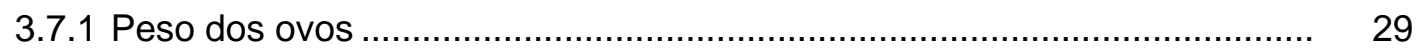

3.7.2 Gravidade específica................................................................. 29

3.7.3 Unidade Haugh................................................................................ $\quad 30$

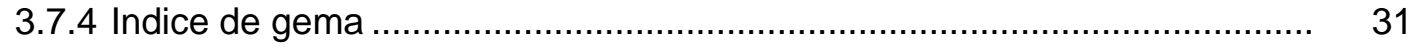

3.7.5 Pocentagem de constituintes ......................................................... 32

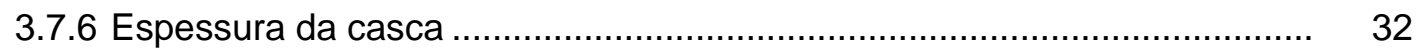

3.7.7 Porosidade da casca ................................................................ 33

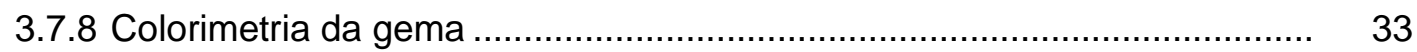

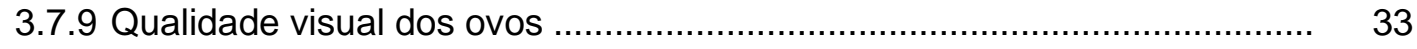

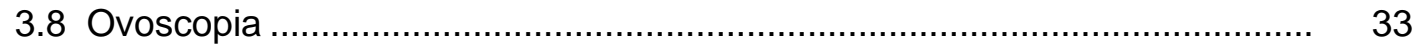

3.9 Avaliação microbiológica ................................................................ 34

3.10 Delineamento experimental............................................................. 35

4 RESULTADOS E DISCUSSÃO ............................................................ 36

4.1 Parâmetros climáticos......................................................................... 36

4.2 Indices de conforto térmico.............................................................. 39

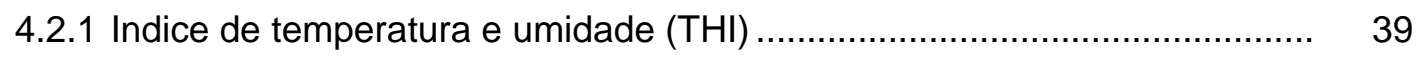

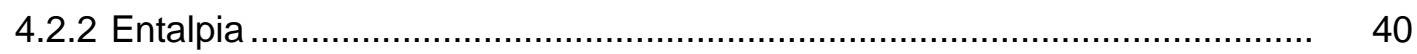

4.3 Parâmetros fisiológicos.................................................................... 42

4.3.1 Temperatura retal e freqüência respiratória............................................. 42

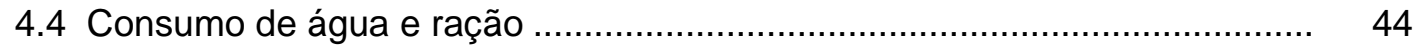

4.5 Parâmetros comportamentais.................................................................. 47

4.5.1 Expressão dos comportamentos para a condição de conforto e sistema de criação "cama+ninho" ......................................................................... 47

4.5.2 Expressão dos comportamentos para a condição de estresse e sistema de criação "cama+ninho". 
4.5.3 Expressão dos comportamentos para o sistema de criação em gaiolas .... 51

4.5.4 Expressão dos comportamentos x Condição ambiental

4.5.5 Tempo gasto na expressão de cada comportamento para a condição de conforto e sistema de criação em cama

4.5.6 Tempo gasto na expressão de cada comportamento para a condição de estresse e sistema de criação em cama.

4.6 Avaliação da técnica de análise de imagenes utilizada

4.7 Níveis de amônia dentro da câmara.......................................................... 74

4.8 Mortalidade …................................................................... 75

4.9 Parâmetros de qualidade dos ovos ..................................................... 75

4.9.1 Peso dos ovos ....................................................................................... 76

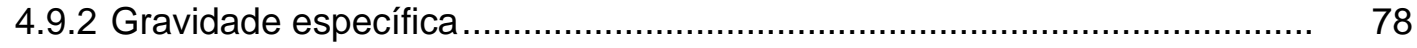

4.9 .3 Unidades Haugh ....................................................................... 79

4.9.4 Porcentagem de constituintes .................................................... 80

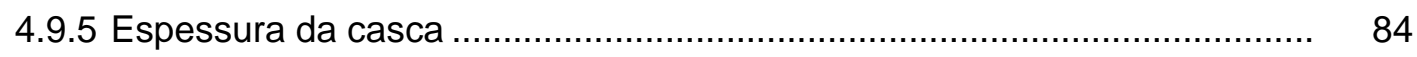

4.9 .6 colorimetria da gema .............................................................................. 86

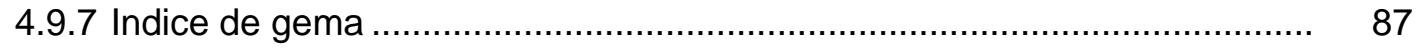

4.9.8 Porosidade da casca .................................................................. 88

4.9 .9 Qualidade visual dos ovos ........................................................ 89

4.9.10 Contaminação dos ovos .................................................................. 91

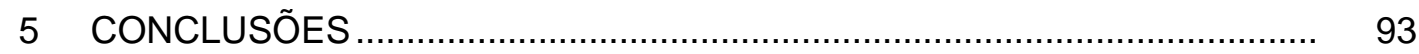

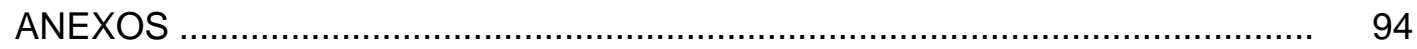

REFERÊNCIAS BIBLIOGRÁFICAS .................................................... 110 


\section{LISTA DE FIGURAS}

Página

1 Divisão da câmara climática em dois boxes e uma bateria de gaiolas .............. 17

2 Croqui da vista horizontal e vertical da câmara climática................................. 18

3 Dimensões das gaiolas $(\mathrm{cm})$, planta baixa e corte transversal. .......................... 21

4 Dimensões dos ninhos $(\mathrm{cm})$, planta baixa e corte transversal.......................... 21

5 Detalhe de duas mini estações meteorológicas instaladas respectivamente a 1,70m (a) e 0,5m (b) de altura com relação ao piso da câmara climática. ........ 22

6 Sistema de marcação individual para a analise de imagens por meio da pintura do dorso das aves.

7 Câmeras de vídeo instaladas no teto da câmara climática (a) e tela do computador equipado com placa de captura e software para imagens (b)....... 25

8 Recipientes com as soluções salinas (a) e ovos sendo avaliados (b)............... 30

9 Avaliação da unidade "Haugh" dos avos ...................................................... 31

10 Medida da altura da gema $(\mathrm{mm})$ com micrometro (a) e do diâmetro da gema (mm) com paquímetro (b).

11 Micrometro de precisão para medidas de espessura (a) e medida da espessura $(\mathrm{mm})$ da casca $(\mathrm{b})$

12 Esquema do ovoscópio utilizado na pesquisa

13 Médias de temperatura de bulbo seco e umidade relativa, durante o período de adaptação em câmara climática para a condição de conforto

14 Médias de temperatura de bulbo seco e umidade relativa, durante o período de adaptação em câmara climática para a condição de estresse 
15 Médias de temperatura de bulbo seco e umidade relativa, durante o período de registro de dados em câmara climática para a condição de conforto

16 Médias de temperatura de bulbo seco e umidade relativa, durante o período de registro de dados em câmara climática para a condição de estresse

17 Valores de THI em câmara climática na condição de conforto (THIreal) e a faixa considerada ideal para aves, com os respectivos limites, inferior e superior de conforto do índice.

18 Índice de temperatura e umidade em câmara climática na condição de estresse (THIreal) e a faixa considerada ideal para aves, com os respectivos limites, inferior e superior de conforto do índice

19 Valores de Entalpia em câmara climática para a condição de conforto (Entalp. Real) e a faixa considerada ideal para aves, com os respectivos limites, inferior e superior de conforto

20 Valores de Entalpia em câmara climática para a condição de estresse (Entalp. Real) e a faixa considerada ideal, com os respectivos limites, inferior e superior de conforto

21 Valores de Temperatura retal (TR), em função das linhagens, condições ambientais e sistema de criação

22 Valores de consumo de água e temp. média da água em função das condições ambientais e sistemas de criação.....

23 Valores médios de consumo de ração em função das linhagens, condições ambientais e sistema de criação

24 Tempo médio gasto na expressão dos comportamentos da linhagem Hy-Line Brown no período da manhã para a condição de conforto

25 Tempo médio gasto na expressão dos comportamentos da linhagem Hy-Line W36 no período da manhã para a condição de conforto

26 Tempo médio gasto na expressão dos comportamentos da linhagem Hy-Line Brown no período da tarde para a condição de conforto.

27 Tempo médio gasto na expressão dos comportamentos da linhagem Hy-Line 
W36 no período da tarde para a condição de conforto

28 Tempo médio gasto na expressão dos comportamentos da linhagem Hy-Line Brown no período da manhã para a condição de estresse

29 Tempo médio gasto na expressão dos comportamentos da linhagem Hy-Line W36 no período da manhã para a condição de estresse

30 Média de tempo gasto na expressão dos comportamentos da linhagem HyLine Brown no período da tarde para a condição de estresse

31 Média de tempo gasto na expressão dos comportamentos da linhagem HyLine W36 no período da tarde para a condição de estresse.

32 Médias dos pesos dos ovos para as condições de ambiente de conforto e de estresse

33 Médias dos valores de gravidade especifica para as condições de ambiente de conforto e de estresse.

34 Médias dos valores de espessura da casca dos ovos para as condições de ambiente de conforto e estresse 


\section{LISTA DE TABELAS}

1 Caracterização dos sistemas de criação em cama e em gaiola.

2 Análise de variância utilizada

3 Valores médios de temperatura retal (TR), para as diferentes linhagens quanto aos sistemas de criação e condições ambientais

4 Valores médios de consumo e temperatura da água para as condições ambientais e sistemas de criação.

5 Valores médios de consumo de ração (g) para as diferentes condições ambientais e sistemas de criação.

6 Porcentagem média de casca, para as duas linhagens e sistemas de criação

7 Porcentagem média de casca, para as duas linhagens e condições ambientais.

8 Porcentagem média de casca, para os dois sistemas de criação e condições ambientais.

9 Porcentagem média de albúmen, para as duas linhagens e condições ambientais

10 Porcentagem média de albúmen, para as duas linhagens e sistemas de criação

11 Porcentagem média de albúmen, para os dois sistemas de criação e condições ambientais.

12 Porcentagem média de gema, para as duas linhagens e sistemas de criação 
13 Porcentagem média de albúmen, para as duas linhagens e condições ambientais

14 Porcentagem média de albúmen, para os dois sistemas de criação e condições ambientais.

15 Porosidade média ( $\mathrm{n}^{\circ}$ poros $/ 0,4 \mathrm{~cm}^{2}$ ), para as condições ambientais e de sistemas de criação avaliados

16 Porcentagem de ovos limpos, sujos e quebrados avaliados visivelmente

17 Número de ovos com ponto de sangue e trincados avaliados pela ovoscopia

18 Teste de contaminação das partes do ovo por coliformes fecais. 


\title{
AVALIAÇÃO DO BEM-ESTAR DE AVES POEDEIRAS EM DIFERENTES SISTEMAS DE PRODUÇÃO E CONDIÇÕES AMBIENTAIS, UTILIZANDO ANÁLISE DE IMAGENS
}

\author{
Autor: JOSÉ ANTONIO DELFINO BARBOSA FILHO \\ Orientador: Prof. Dr.IRAN JOSÉ OLIVEIRA DA SILVA
}

\section{RESUMO}

A utilização de sistemas de bateria de gaiolas é assunto de grande polêmica nos países da Europa, sendo que a maior preocupação com o uso de gaiolas se dá quanto ao espaço oferecido às aves poedeiras, o qual certamente afeta seu bem-estar. Sendo assim este trabalho teve como objetivos avaliar os aspectos relacionados ao comportamento e bem-estar das aves, comparando o sistema de criação convencional (bateria de gaiolas) com um sistema de criação em cama, ninho e poleiro, bem como avaliar a influencia das condições ambientais (estresse e conforto) na qualidade final dos ovos, associando técnicas da zootecnia de precisão (análise de imagens), para avaliar as respostas comportamentais das diferentes linhagens nas diferentes condições. Dois grupos de 20 aves (10 Hy-line W36 e $10 \mathrm{Hy}$-line Brown) em inicio de postura foram submetidas a duas condições ambientais durante duas semanas consecutivas $\left(26^{\circ} \mathrm{C}\right.$ e $60 \%$ UR e $35^{\circ} \mathrm{C}$ e $70 \%$ UR), sendo também submetidas a dois sistemas de criação (bateria de gaiolas e cama). Durante o período de avaliação um sistema de câmeras de vídeo registrava o comportamento das aves. Os ovos 
produzidos durante todo o período da pesquisa foram avaliados pela análise dos seguintes parâmetros de qualidade: peso do ovo, espessura da casca, gravidade especifica, unidades Haugh, além de análise da colorimetria da gema, porosidade da casca e análises microbiológicas, para a verificação de uma possível ocorrência de contaminação por Salmonella sp na gema e casca dos ovos. Os resultados obtidos revelaram uma redução significativa $(P<0,05)$ nos parâmetros de qualidade do ovo para a condição de estresse térmico, principalmente para o sistema de criação em gaiolas. Quanto as análises de comportamento, o sistema de criação em cama proporcionou a expressão de todos os comportamentos naturais e de conforto das aves, favorecendo assim melhores condições de bem-estar. Para o sistema de criação convencional (gaiolas) foi possível verificar que mesmo sem nenhuma condição, as aves ainda tentavam executar seus comportamentos naturais, sendo que a impossibilidade de expressarem estes comportamentos certamente agravou a condição de estresse provocada por este sistema de criação. Pela análise dos dois sistemas de criação e das duas condições ambientais a linhagem Hy-Line W36. foi a que obteve um melhor desempenho. 


\title{
WELFARE EVALUATION BY IMAGE ANALYSIS OF LAYING HENS IN DIFFERENT HOUSING SYSTEMS AND ENVIRONMENTAL CONDITIONS
}

\author{
Author: JOSÉ ANTONIO DELFINO BARBOSA FILHO \\ Adviser: Prof. Dr. IRAN JOSÉ OLIVEIRA DA SILVA
}

\section{ABSTRACT}

The battery cage system is a very polemic issue in European countries, being the most commonly raised concerns focused on the spatial restrictions of the hens, which might compromise important comfort movements affecting their welfare conditions. This work aimed to evaluate aspects related to behavior and welfare of hens comparing a conventional housing system (laying cages in battery) with another system using litter, lair and roost. In addition, the effects of environmental conditions (stress or comfort) on final egg quality and behavior responses (analyzed by precision techniques) were evaluated in different laying hen lines. Two groups of 20 birds (10 Hyline W36 and $10 \mathrm{Hy}$-line Brown) at the beginning of production phase were submitted to two environmental conditions $\left(26^{\circ} \mathrm{C}\right.$ with $60 \% \mathrm{RU}$ or $35^{\circ} \mathrm{C}$ with $\left.70 \% \mathrm{RU}\right)$ and two housing systems (cages in battery or litter) during two consecutive weeks. During the evaluation period, bird behaviors were recorded by video cameras. Total egg production was analyzed according to egg weight, shell thickness, specific gravidity, Haugh unit, yolk colorimetric parameters and shell porosity. Eggs were microbiologically analyzed in order to detect Salmonella sp contamination in yolk and eggshell. A 
significant $(P<0.05)$ reduction in quality parameters was observed in eggs from laying hens raised under heat stress, mainly in those from laying cage system. In relation to behavior, the housing system in litters proportioned the expression of all natural behaviors and those related to bird comfort, which permitted to improve welfare conditions. In conventional system (laying cages) was verified that birds tried to manifest their natural behavior in spite of lacking condition for it. This impossibility for executing natural behaviors promoted an increase of stress provoked by the housing system. Analyzing both systems and environmental conditions, hens from Hy-Line W36 showed the better performances. 


\section{INTRODUÇÃO}

A avicultura de postura hoje no Brasil apresenta-se bem tecnificada, a maioria das granjas caminha para uma automatização completa dos seus processos de produção e a genética é a maior responsável pelas altas produções alcançadas pelas poedeiras atualmente. Apesar do setor de produção de ovos estar passando hoje por uma situação estática com relação aos últimos cinco anos, há uma tendência de mudanças para um futuro próximo. Um dos indícios que viria confirmar esta tendência é a mudança de instalações e de manejo para a criação de aves poedeiras que logo estará sendo exigida pela União Européia (EU), para atender as legislações de bemestar animal.

Entre as principais mudanças propostas pela União Européia, está a troca do atual sistema de bateria em gaiolas, por um sistema que possibilite às aves expressar os seus comportamentos naturais, tais como: utilizar o ninho para a postura, tomar banho de areia, empoleirar ou ainda bater e esticar as asas, sendo isso uma conseqüência das mudanças e exigências de um novo tipo consumidor, que vem se tornando cada vez mais comum nos dias de hoje e que está cada vez mais preocupado com as regras em prol do bem-estar dos animais de produção e com a qualidade do alimento que consome.

Essas exigências propostas pela União Européia poderão colocar o Brasil em ótima situação quanto ao que se refere à exportação de ovos, pois estas poderão ser facilmente atendidas, já que o Brasil possui uma grande disponibilidade de área (o que para outros países é fator limitante), tendo em vista que as novas normas de criação exigem maior espaço para as aves, área com cama e ninho, além, é claro, da eliminação das gaiolas.

O plantel de poedeiras em 2003 foi de aproximadamente 79 milhões de aves e a produção esteve em torno de 62,6 milhões de caixas de 30 dúzias. No Brasil, 
o consumo per capita/habitante/ano foi de aproximadamente 81,7 ovos em 2002 e 87,5 em 2003, apresentando um crescimento em torno de $8 \%$ no consumo de ovos, sendo a região sudeste a de maior consumo per capita (176 ovos/hab/ano), Avicultura Industrial (2004). Para 2004, até o segundo trimestre, foram produzidos 475,29 milhões de dúzias de ovos, um aumento de $1,71 \%$ sobre o primeiro trimestre de 2004, IBGE (2004). Quanto às exportações, o Brasil vem se destacando e aumentando sua participação neste cenário a cada ano. Segundo dados da World Egg Exports o Brasil exportou cerca de 76 milhões de unidades em 2001, apresentando um aumento de mais de $500 \%$ com relação ao ano de 1995, o que indica a crescente demanda pelo nosso produto, ANUALPEC (2004).

Como se pode notar, uma das maiores perspectivas do setor com relação ao futuro, diz respeito ao mercado externo. Existe uma forte tendência na Europa para que cada poedeira ocupe uma área mínima de $500 \mathrm{~cm}^{2}$. A nova legislação deve beneficiar o Brasil que pode se tornar nos próximos anos um dos principais exportadores, em função de suas condições naturais (área), altamente favoráveis ao novo sistema de produção de ovos proposto.

As limitações impostas pela recente legislação em alguns países europeus, em relação ao espaço nas gaiolas e o banimento destas, sob a alegação do bem-estar das aves, devem abrir espaço para as exportações brasileiras, uma vez que o custo da produção extensiva inviabilizará muitas granjas em outros países.

Este fato é confirmado pelas notícias que relatam as exigências de alguns grandes consumidores e redes varejistas que impõem métodos de produção, utilizando aves não criadas em gaiolas, ou em número inferior ao usado no momento, sendo que até nos Estados Unidos a cadeia McDonalds está pedindo a seus fornecedores que ampliem a área de gaiola dos atuais $335,5 \mathrm{~cm}^{2}$ por ave, para $464,5 \mathrm{~cm}^{2}$, insistindo ainda em não utilizar a prática da debicagem e não induzir a muda forçada.

Com base nestas novas tendências comerciais, serão necessárias mudanças radicais nas instalações para poedeiras, além de mudanças também na genética, visando uma adequação de linhagens que se encaixem nos novos moldes do mercado. Por outro lado, segundo Becker (2002), deve-se considerar também que a criação intensiva exige adaptações fisiológicas e comportamentais dos animais que, por sua vez, devem ser estudadas para avaliar os sistemas de manejo mais adequados. 
Sendo assim, este trabalho teve como objetivo principal avaliar aspectos relacionados ao comportamento animal, principalmente quanto à presença de cama ou de ninho em substituição ao sistema de gaiolas convencional, tendo em vista aspectos relacionados à qualidade do ovo, além do estudo de diferentes linhagens comerciais quanto ao seu comportamento em diferentes condições ambientais.

São também considerados como objetivos específicos:

- avaliar a influência das diferentes condições ambientais (Temperatura e UR) na preferência pela postura na cama ou no ninho, em função de cada linhagem estudada;

- analisar o comportamento das diferentes linhagens, utilizando a tecnologia de análise de imagens;

- avaliar qual das linhagens comerciais estudadas será a mais indicada para o novo conceito de produção de ovos em ninho;

- analisar a influência dos sistemas de produção (cama+ninho e gaiolas), nos parâmetros de qualidade dos ovos. 


\section{REVISÃO DE LITERATURA}

\subsection{Ambiência para aves de postura}

O conforto animal, até há alguns anos atrás, era visto como um problema secundário, tanto do ponto de vista ecológico quanto produtivo. Presumia-se que o desconforto térmico seria resolvido com o uso de condicionamento artificial, sem considerar os custos e problemas de implantação de um sistema. Porém, na ultima década, a preocupação com o conforto animal vem crescendo notoriamente, principalmente quando associado às respostas fisiológicas como indicadoras do conforto animal, Silva (2001).

Com relação ao efeito da temperatura nas aves de postura, existem muitos estudos que mostram a existência de uma zona de conforto térmico, na qual é conveniente que o animal esteja. Entretanto a determinação da zona de conforto térmico envolve o conhecimento e as interações de muitas variáveis que podem influenciar nesse processo (umidade, manejo, ventilação, instalações, etc...). Para condições tropicais, Silva (1998) propõe modelos matemáticos para predizer os efeitos da temperatura e sistemas de climatização na produção de ovos.

Segundo Smith (1964), zona de conforto é aquela em que a resposta animal ao ambiente é positiva e a demanda ambiental é conciliada com a produção basal, acrescida da produção de calor equivalente à atividade normal e do incremento calórico da alimentação. Nessa zona (variável para cada tipo de fase e manejo), o animal alcança seu potencial máximo, e a temperatura corporal é mantida com a mínima utilização de mecanismos termorreguladores.

Por outro lado, de acordo com Von Borell (1995), estresse é um termo geral que implica uma ameaça à qual um determinado organismo precisa se ajustar. Segundo 
Fraser et al. (1975), diz-se que um animal está em estado de estresse quando se faz necessário que faça ajustes em sua fisiologia ou em seu comportamento, para ajustarse aos aspectos adversos decorrentes do manejo ou do ambiente onde se encontra.

Normalmente, a temperatura normal do corpo de uma ave poedeira é, em média, de $41^{\circ} \mathrm{C}$, sendo que durante os dias de calor a temperatura pode atingir até $43^{\circ} \mathrm{C}$. A partir daí então o animal já está sujeito ao estresse térmico e para cada grau acima desse valor, o consumo de alimentos começa a diminuir e a produção ficará comprometida, Nakano (1979).

O desconforto térmico em aves de postura também provoca uma série de conseqüências que, por sua vez, estão intimamente ligadas à queda no consumo de ração, menor taxa de crescimento, maior consumo de água, aceleração do ritmo cardíaco, alteração da conversão alimentar, queda na produção de ovos e maior incidência de ovos com casca mole.

Payne (1967) verificou em seu trabalho que as quedas na produção de ovos sob altas temperaturas não são só provocadas necessariamente pelas altas temperaturas, mas também pela diminuição na ingestão de nutrientes essenciais de energia, resultando, assim, numa diminuição do apetite. Notou também que a postura não era afetada, mesmo quando atingida temperatura de $36^{\circ} \mathrm{C}$ durante 6 horas ao dia, sempre que as aves tivessem se aclimatado a ela e que a umidade relativa estivesse na faixa de 40 a 50\%. Quanto à conversão alimentar, quase sempre tem se observado uma melhora ao se aumentar a temperatura ambiente. Porém, isso só seria possível no caso de se mudar a concentração da ração sem que a produção ficasse prejudicada.

As diferentes linhagens de aves também demonstram diferentes graus de tolerância ao calor. Como exemplo, tem-se que as linhagens derivadas da Leghorn branca demonstram, em relação às demais, uma maior capacidade de tolerância a temperaturas mais elevadas, devido a certas características anatômicas que favorecem uma melhor perda de calor corporal, Nakano (1979).

Atualmente, vários são os estudos realizados no sentido de se reduzir o estresse calórico. Porém, há uma necessidade de se associar o ambiente, o potencial genético das poedeiras e também a eficiência energética da ração, Silva (2001).

Quanto a baixas temperaturas, o maior inconveniente é o aumento do consumo de ração, como uma reação natural para incrementar a ingestão da energia necessária 
à manutenção de todas as atividades vitais. O consumo mais alto é encontrado entre 5 e $10^{\circ} \mathrm{C}$, Fabrello (1979).

Quanto à umidade do ar ideal para aves de postura, não há valores concretos como no caso da temperatura. O que se pode afirmar com certeza é que, com valores muito altos de umidade relativa, as aves ficam mais sensíveis ao estresse calórico. Por isso, é importante se manter uma baixa umidade relativa no aviário, principalmente no verão. Outro problema sério causado pela alta umidade relativa nos aviários que utilizam cama, ao invés de gaiolas, é seu umedecimento, o que além de trazer problemas de saúde as aves, ainda poderá comprometer a qualidade dos ovos ali postos.

Segundo Payne (1967), quando a umidade relativa noturna é constante e superior a $80 \%$ e a diurna superior a $72 \%$, o nível de umidade da cama passará de $32 \%$ e ficará totalmente úmida.

Borbas \& Minvelle (1997) avaliaram os efeitos da temperatura ambiental em aves poedeiras de diferentes linhagens e, ao submeter as aves a ambientes com temperatura de $21^{\circ} \mathrm{C}$ e $35^{\circ} \mathrm{C}$, observaram que houve uma redução na ingestão de alimentos (16\%), no número de ovos (13\%), no peso corporal $(8 \%)$, e no peso dos ovos (4\%), e que não houve diferença no desempenho entre as diferentes linhagens.

Atenção especial deve ser dada às instalações que devem proporcionar as melhores condições possíveis de conforto térmico aos animais. Isso alerta os avicultores para a importância fundamental de um sistema funcional de ventilação nos aviários, os quais devem sempre ser orientados no sentido de que o ar quente possa ser facilmente renovado, e permitindo também a entrada de ar fresco para que as aves se sintam confortáveis e sua produção não seja comprometida, Nakano (1979).

\subsection{Respostas Fisiológicas}

As aves são animais homeotermos, apresentando a capacidade de manter sua temperatura interna constante, mas de maneira geral, não se ajustam muito bem a extremos de temperatura, o que, por sua vez, poderá causar alterações fisiológicas que comprometerão a qualidade e a produção dos ovos.

A temperatura corporal de uma ave oscila em torno de uma faixa de $41^{\circ} \mathrm{C}$, e o controle desta temperatura se faz através das trocas de calor com o meio. Se uma ave 
se encontra em condições de temperatura e umidade elevadas, terá sérias dificuldades de perder ou trocar calor com o ambiente, ocasionado, assim, um aumento da temperatura corporal.

Para acompanhar as mudanças na temperatura corporal das aves, utiliza-se como variável resposta a temperatura retal, que dará uma idéia de como o organismo em questão está reagindo às condições ambientais a que está exposto.

Payne (1967) demonstrou em seus trabalhos que quedas na produção de ovos em aves submetidas ao estresse térmico não são necessariamente provocadas pelas altas temperaturas, mas que são também resultados da diminuição na ingestão de alimentos e nutrientes essenciais às aves, ocasionada principalmente pela perda de apetite provocado pelo estresse.

Além de ocorrer aumento da temperatura retal, sob estresse térmico as aves apresentam também aumento da ofegação, que é uma forma de perda de calor latente por meio da evaporação do calor corpóreo na tentativa de evitar a hipertermia. Esse aumento na ofegação das aves é medido pela contagem da freqüência respiratória.

Segundo Lasiewski et al. (1966), citado por Freeman (1988), a ofegação nas aves é um dos meios mais eficientes de se dissipar o calor em condições de estresse térmico, sendo ainda que, se a umidade relativa estiver apropriada, a maioria das aves será capaz de dissipar seu calor metabólico através da ofegação.

Outro fator importante relacionado com os métodos possíveis de troca de calor dos animais é o aumento no consumo de água. Segundo Sturkie (1967), a ave, quando sente calor, pode beber mais água que o usual, sendo, portanto, o consumo de água maior em ambientes mais quentes.

Estudos, como os de Beker \& Teeter (1994) e Macari (1995), chamam a atenção também para o aspecto da temperatura da água fornecida às aves, uma vez que esta interfere no seu consumo, que tende a diminuir, quando a temperatura da água aumenta.

Dados citados por Costa (1980), mostram que, com temperaturas ambientais superiores a $30^{\circ} \mathrm{C}$, o consumo de água pode atingir até $0,5 \mathrm{l} / \mathrm{ave}$ dia, e a principal razão para este consumo seria o aumento da perda de água pelo processo de perda de calor por evaporação. 


\subsection{Qualidade dos ovos}

A qualidade da produção é, sem duvida nenhuma, um dos principais interesses dos produtores e consumidores de ovos, uma vez que está diretamente relacionada a fatores como: higiene, sanidade e principalmente a saúde e bem-estar dos animais.

Muitos estudos têm sido conduzidos a fim de se verificar a influência do estresse térmico na qualidade dos ovos, e estes só reforçam o que foi relatado por Bennion \& Warren (1993), em seu trabalho com poedeiras submetidas a altas temperaturas, em que foi verificada uma certa influência das altas temperaturas na qualidade das cascas dos ovos, além de um decréscimo nos valores de peso dos componentes constituintes do ovo.

Segundo Pereira (1991), o pH sangüíneo das aves de postura decresce juntamente com o nível de cálcio, após duas horas de estresse térmico. Isso é prejudicial à formação da casca do ovo, pois há uma diminuição de cálcio no sangue.

Andrade et al. (1976) verificaram que aves expostas a uma temperatura de $32^{\circ} \mathrm{C}$ apresentaram um decréscimo significativo em sua produção de ovos, além de um decréscimo de aproximadamente $25 \%$ no consumo de ração. Quanto à qualidade dos ovos, o estudo revelou um decréscimo significativo no peso dos ovos, nos valores de gravidade especifica e na espessura da casca.

Em seu trabalho, Mashaly et al. (2004) submeteram aves poedeiras de 31 semanas a três tratamentos em câmara climática, com temperaturas cíclicas e sob condição de estresse térmico constante de $35^{\circ} \mathrm{C}$ e $50 \%$ UR. Como resposta, verificaram que o ganho de peso das aves e o consumo de ração foram significativamente reduzidos nas condições de estresse, bem como o peso dos ovos e da casca, a espessura da casca e a gravidade especifica.

Um fator mundialmente conhecido para se avaliar a qualidade dos ovos é a unidade "Haugh", que, segundo seu criador Haugh (1937), descreve em seu trabalho que esta medida é na verdade um fator de correção para o peso do ovo, uma vez que verificou que a qualidade dos ovos variava com a altura da clara.

Segundo Rodrigues (1975), a unidade "Haugh" é uma expressão matemática que correlaciona o peso do ovo com a altura da clara espessa, sendo que, de modo geral, quanto maior o valor da unidade "Haugh", melhor a qualidade do ovo. 
Sauver, citado por Silversides et al. (1993), pôde concluir em seus estudos que a medida unidades "Haugh" tem pouca relação com parâmetros de qualidade nutricional. Já Fletcher et al. (1983) verificaram que o valor de unidades "Haugh" para ovos frescos diminui com o aumento da idade das aves.

Quanto à importância da integridade da casca dos ovos com relação à incidência e a possibilidade de uma contaminação por bactérias ou ainda pela constatação da presença de coliformes, possivelmente oriundos da cama, se faz necessário estudos como o realizado por Sauter \& Peterson (1974), que constataram que ovos com valores baixos de gravidade específica eram mais susceptíveis a penetração por Salmonella.

O que ocorre é que, no momento da postura, a temperatura do ovo é de aproximadamente $38^{\circ} \mathrm{C}$ e a casca ainda se encontra úmida, esta umidade por sua vez favorece a aderência de microrganismos à superfície externa do ovo. À medida que o ovo vai "esfriando" ao sair da cloaca, ocorre uma ligeira contração das partes internas, o que resulta em uma pressão negativa dentro do ovo. Neste momento, certas bactérias e fungos podem ser transportados para o interior da casca e conseqüentemente, virem a contaminar o ovo, Silva (1994).

\subsection{Comportamento avícola}

Por que as aves têm a necessidade de ciscar? Por que precisam de ninho para botar? Ou ainda, como e por que o comportamento animal influencia a produtividade?

Para responder a estas e outras perguntas pertinentes às ações e reações dos animais, quando submetidos a diferentes estímulos e à influência destas reações na produção é que se faz necessário o estudo do comportamento animal.

Segundo Kilgour \& Dalton (1984), a ave tem flexibilidade limitada, mas boa capacidade de discriminação visual. Embora relute em voar, usa o espaço horizontal (solo) para comer, tomar banho de areia e construir o ninho. E o espaço vertical para dormir e ficar empoleirada. Em todas as épocas do ano, a maior parte do dia está associada à busca de alimento e faz isso principalmente ciscando o solo e folhas, Dawkins (1989).

O grau de confinamento ao qual a ave poedeira está sujeita, hoje em dia, é extremamente alto e impõe severas restrições ao seu comportamento animal. 
Normalmente, são usadas gaiolas contendo de 3 a 5 aves, e medem de 30 a $35 \mathrm{~cm}$ de largura por $43 \mathrm{~cm}$ de comprimento. Sob tais condições, as aves não podem esticar suas asas, nem se mover sem esfregarem-se umas nas outras ou se levantar totalmente no fundo da gaiola (o chão da gaiola é inclinado para que o ovo role em direção à calha coletora), Singer (1991).

Grande parte do padrão de comportamento normal da ave é frustrado pelo engaiolamento. O comportamento de acasalamento, incubação e cuidado com os pintinhos é impedido, e a única compulsão reprodutiva permitida é a de pôr ovos. Elas não podem voar, ciscar, se empoleirar nem andar livremente. É difícil para a ave limpar suas penas e é impossível se "sujar" com terra, Singer (1991).

A comparação de estudos de comportamento de aves selvagens e domesticadas em ambientes controlados pelo homem indica que o repertório comportamental das aves em ambientes não confinados, em geral, é preservado, havendo mudanças na freqüência e na intensidade das características comportamentais, Craig (1992).

A seleção genética de aves em confinamento não muda o seu comportamento quando criadas soltas. Comparando a linhagem comercial ISA com aves caipiras, Sales et al. (2000) verificaram o mesmo padrão geral de comportamento entre as duas linhagens.

Outro importante comportamento que não pode ser modificado é o banho de areia. A seqüência deste comportamento é realizada mesmo quando as aves estão sobre o piso de arame das gaiolas. Appleby et al. (1993) investigaram a motivação para este comportamento em poedeiras e constataram que a experiência prévia poderia ser um fator importante.

Segundo Fraser (1999), as tentativas de se conceituar o bem-estar animal resumem-se em três pontos principais:

$>\quad$ os animais devem se sentir bem, não devendo ser submetidos ao medo ou a dor de forma intensa ou prolongada;

$>$ os animais devem estar bem, no sentido de saúde, crescimento e funcionamento fisiológico;

$>\quad$ os animais devem levar uma vida natural, através do desenvolvimento e do uso de suas adaptações naturais. 
Outro ponto muito importante a ser levantado é o do comportamento social das aves domésticas, tendo-se em vista as condições intensivas de criação nos dias de hoje.

Segundo Maudlin (1992), a organização social tem duas funções importantes: reduzir os gastos não adaptativos de energia, e servir de base para relações regulares de dominância e submissão. Essas relações são geralmente estabelecidas através de comportamentos agressivos, representados principalmente pela bicagem de penas, que, segundo Fraser \& Broom (1990), é um comportamento anormal resultante da frustração do comportamento exploratório em um ambiente sem diversificação (gaiola). Assim, ao invés de bicarem o solo em busca de alimento, passam a investigar o corpo de outros animais. Isso causa prejuízo aos avicultores e é a principal motivação para o corte da ponta dos bicos das aves (debicagem), feita com uma lâmina aquecida. Essa lâmina é aplicada na ponta do bico das aves, por onde correm vasos sanguíneos, causando dor e sofrimento às aves.

A conseqüência mais séria da bicagem de penas é o sangramento, que pode levar as aves ao canibalismo. Isso foi constatado por Cloutier et al. (2000), que verificaram uma alta correlação entre a bicagem de penas e o canibalismo em poedeiras Leghorn.

Uma forma de amenizar a bicagem de penas seria a preferência pela adoção de substrato (cama) ao invés de gaiolas. O efeito positivo do fornecimento de substrato foi comprovado por Nicol et al. (2000), que verificaram que o fornecimento de maravalha reduziu significantemente o comportamento de bicar penas em poedeiras em comparação às mantidas em gaiolas. Além disso, destacou que, na presença de maravalha, as poedeiras deixavam de bicar penas, e passavam a bicar mais o chão.

\section{$2.5 \quad$ Respostas Comportamentais}

Segundo Odén (2003), a maioria dos comportamentos apresentados pelas aves domésticas atuais são baseados nos comportamentos considerados como padrão pelas suas ancestrais (Red Jungle Fowl), tais como a dominância dentro do grupo, o comportamento de ciscar o chão, a agressividade e a construção do ninho.

A comparação de estudos de comportamento de aves selvagens e domesticadas indica que o repertório comportamental destas aves em ambientes não 
confinados em geral é preservado, havendo, no entanto, mudanças na freqüência e na intensidade das características comportamentais, Craig (1992).

De acordo com Sales et al. (2000), o fato de a ave pertencer a uma linhagem voltada para a produção e confinamento não altera seu comportamento padrão quando criada solta, pois comparando a linhagem comercial ISA com aves caipiras, puderam constatar que as aves apresentavam o mesmo padrão geral de comportamentos.

Já foi comprovado também por estudos, como os realizados Hughes \& Duncan (1988) e por Jensen \& Toates (1993), que o maior problema de animais criados em confinamento (gaiolas) é a impossibilidade de expressar seus comportamentos naturais, o que leva os animais à frustração e a desenvolver comportamentos anômalos.

Segundo o trabalho realizado por Rudkin \& Stewart (2003), que monitoraram, através de câmeras de vídeo, os comportamentos de duas linhagens de poedeiras em diferentes tipos de gaiolas modificadas, foi possível verificar a expressão da maioria dos comportamentos naturais das aves, mesmo em condições de confinamento.

\subsection{Postura em Cama e Ninho}

A cama nunca foi um objeto de muitos estudos ou um assunto prioritário para as empresas produtoras de ovos. O fato é que agora, com os novos rumos do mercado e exigências dos consumidores, e novos métodos de manejo e instalações, o assunto "cama para aves de postura" volta a figurar no cenário industrial, e pode ser considerado de grande importância, uma vez que a maioria das pesquisas sobre cama são feitas para frangos de corte e existem poucos estudos abordando 0 comportamento de aves de postura com relação à cama, sem falar também nos aspectos relacionados à qualidade do ovo quando este é posto na cama.

Segundo Paganini (2002), pode-se falar que cama é todo material distribuído sobre o piso de galpões para servir de leito às aves. E tem como função absorver a umidade eliminada pelas aves através das fezes, bem como da água de equipamentos (bebedouros).

Esse controle de umidade no piso é muito importante para a qualidade sanitária das aves e dos ovos, uma vez que a postura será diretamente na cama, e este contato 
poderá contaminar o ovo, pois ficando em contato com a cama, bactérias poderão penetrar em sua casca, Pulici (2001). A cama tem também a função de isolante térmico, característica muito importante nos períodos frios, pois evita a perda de calor para o piso.

Além dessas funções, a cama está intimamente relacionada com o comportamento das poedeiras com relação à produção de ovos, possui a função de proporcionar à ave uma superfície macia para permitir o seu repouso e estimular a postura de ovos pela simulação das condições do ninho.

Os materiais a serem utilizados como cama devem apresentar algumas características, tais como: maciez, serem absorventes, isotérmicos, livres de fungos, e não tóxicos, além de baixo custo e fácil disponibilidade. Vários são os materiais que podem ser utilizados como cama, entre eles fenos de gramíneas, maravalha, palha de feijão ou arroz, casca de café, entre outros. É importante salientar que alguns destes materiais são vulneráveis à formação de placas superficiais compactas, compostas por fibras e fezes. Essa compactação pode dificultar a difusão de umidade da cama, e as aves ficando em contato intenso com as próprias fezes, poderão vir a apresentar lesões e necroses cutâneas, Jorge et al. (1997).

A qualidade e boa conservação da cama e do piso têm grande importância e influência sobre as condições dos ovos. O excesso de umidade da cama faz com que as aves com suas penas ou pés úmidos manchem os ovos, enquanto transitam pelo chão do aviário. Isso decorre em perda na qualidade dos ovos, uma vez que, além de sujos ainda poderão estar contaminados, Elson (1968).

Atenção especial também deve ser dada à densidade de aves sobre a cama. $\mathrm{O}$ aumento na densidade resulta em maior compactação da cama, diminuindo, assim, a sua capacidade de absorção de umidade. Quando se aumenta a densidade, deve-se também aumentar a altura da cama, bem como revolvê-la mais freqüentemente.

Como já mencionado anteriormente, os novos moldes de criação exigidos pela União Européia (EU) constam de novas gaiolas, as chamadas de "enriched cages", que, traduzindo, seriam "gaiolas enriquecidas". Estas constariam de uma área de cama, poleiro e ninho. Como já mencionado também, ovos postos diretamente na cama perdem sua qualidade, pois propiciam a entrada de bactérias, fazendo com que este ovo tenha que ser descartado, resultando em prejuízos para o avicultor, Avisite (2002). 
Uma forma de se garantir a boa conservação dos ovos seria fazer com que as aves voltassem as suas origens, ou seja, fazer com que elas botassem no ninho. Isso também tem uma relação muito importante no tocante ao comportamento animal, uma vez que se presume ser da própria natureza da ave a confecção de ninhos no intuito de proteger os ovos.

O problema é que, atualmente, a alta evolução nos setores da avicultura de postura e o grande avanço da genética nas linhagens comerciais de aves cada vez mais produtivas estão fazendo com que as linhagens "percam" um pouco seus princípios normais de comportamento animal, ou seja, devido aos avanços genéticos, as aves se "esqueceram" de que seu comportamento natural "manda" que se deva botar no ninho. Por isso, as aves teriam que passar por uma espécie de "nova adaptação" para poderem readquirir o comportamento de seus ancestrais.

Esta "nova adaptação" seria a chave para que as linhagens comerciais de hoje voltassem a procurar o ninho para botar. Isso implicaria em ovos com maior qualidade externa e interna, uma vez que estariam longe da contaminação da cama.

\subsection{Avicultura de Precisão}

A avicultura, hoje em dia, caminha a passos largos para cada vez mais alcançar maiores produções, acompanhada por inovações tecnológicas, como a automação de quase todo o setor de produção e também pelas mudanças marcantes nas áreas de genética e nutrição.

Com todos estes avanços, torna-se necessário o monitoramento das variáveis do ambiente em que se encontram as aves, além do comportamento destas, quando submetidas a diferentes condições ambientais, e suas reações, quando submetidas a mudanças comportamentais, tais como, mudança nas instalações, ou ainda a adaptação a um novo tipo de manejo (retirada das gaiolas).

Surge então a importância de se ter um modo rápido e preciso de monitorar constantemente o comportamento e reações das aves. Segundo Nääs (1994), a precisão está diretamente relacionada com o efetivo monitoramento e com o controle das etapas de produção, pois não é possível imprimir uma melhoria num processo qualquer, se este não for conhecido em todas as suas fases. A precisão é uma 
ferramenta que utiliza meios eletrônicos e de comunicação no sentido de diminuir perdas em um determinado processo.

Denomina-se avicultura de precisão o emprego de sensores e atuadores para a coleta de informações inerentes ao ambiente e a interferência em processos psicrométricos para a alteração das variáveis de ambiente do galpão. Consiste ainda em utilizar métodos avançados de controle e rastreamento, em que geralmente são utilizados sistemas de automação, visando, principalmente, reduzir ou evitar perdas localizadas, otimizando, assim, o sistema de produção. O conceito fundamental é conseguir um controle preciso sobre a utilização dos recursos envolvidos nos processos que se encontram na cadeia de produção, Nääs (1994).

Segundo Fialho (1999), sistemas de automação são aqueles que permitem monitorar e controlar o funcionamento de um sistema físico de forma segura. 0 monitoramento tem o objetivo de registrar ocorrências de um determinado evento, bem como alertar o usuário em caso de situações excepcionais.

Sendo assim, os sistemas de automação necessitam de algum tipo de interface que lhes permita avaliar o estado atual do sistema. Daí surgem os sensores, que têm a função de medir as variáveis envolvidas no processo e transformá-las em informações que possam ser interpretadas pelo homem. Para que um sistema de automação funcione perfeitamente, faz-se necessário o controle das informações recebidas pelos sensores, para que possam ser encaminhadas para os atuadores. Isso é feito pelos controladores, cuja principal função seria a de coordenar e harmonizar o sistema.

Uma tecnologia que vem sendo muito utilizada e difundida, nos dias de hoje, é a análise de imagens como ferramenta para se estudar o comportamento animal. Segundo Xin et al. (1998), o sistema consiste em uma microcâmera, uma placa de captura de imagem instalada em um PC e um programa visual que execute a aquisição, processamento e a classificação das imagens dos animais.

Segundo Abrahamsson (1996), o comportamento animal até há pouco tempo era medido através da observação visual dos animais, o que consumia mais tempo, era subjetivo e muito susceptível ao erro humano. A automação deste processo, por meio de câmeras de vídeo e programas de interpretação de imagens, tornou possível uma melhor interpretação dos comportamentos dos animais sem a necessidade de estar perto deles ou de incomodá-los. 
Leroy et al. (2003) desenvolveram um sistema de análise de imagens com uma técnica de processamento on-line para quantificar os comportamentos de aves de postura e para posterior comparação com o sistema de observação visual humano. Eles concluíram que ambos os sistemas de análise podem ser utilizados na avaliação dos comportamentos das aves, embora o sistema de observação visual humano tenha propiciado maior número de erros na quantificação total dos comportamentos, quando comparado com o sistema de vídeo automatizado.

Dusenbry (1985) demonstrou a viabilidade de se observar, simultaneamente, 25 aves por meio de uso de microcomputador e de uma câmera de vídeo. Neste trabalho, o autor comenta a possibilidade de se fazer um registro individual e simultâneo dos movimentos efetuados pelos 25 animais, sendo possível obter dados do seu comportamento por meio de um equipamento relativamente barato que proporcionou a coleta de imagens em tempo real, por meio do processamento de imagens.

A avaliação e os controles interativos do conforto térmico dos animais pela análise de imagens supera os problemas inerentes ao método convencional, pois utilizam-se os próprios animais como biosensores em resposta aos reflexos do ambiente por meio de análise comportamental, Xin \& Shao, (2002).

No Brasil, a técnica de análise de imagens para o estudo do comportamento animal tem sido utilizada para avaliar diferentes tipos de animais de produção, tais como para bovinos (Perissinotto, 2003; Matarazzo, 2004), suínos (Pandorfi, 2002) e aves (Sevegnani et al. 2001).

Pandorfi (2002) utilizou o sistema de análise de imagens para verificar o comportamento de leitões, quando submetidos a diferentes sistemas de aquecimento (piso térmico e resistência elétrica), e pôde verificar que entre as ferramentas tecnológicas utilizadas em sua pesquisa, a análise de imagens foi a que se mostrou mais eficiente, pois permitiu correlacionar o perfil de distribuição dos animais e captar um grande número de informações. 


\section{MATERIAL E MÉTODOS}

\subsection{Local de desenvolvimento da pesquisa}

A pesquisa foi realizada em câmara climática nas dependências do Núcleo de Pesquisa em Ambiência (NUPEA), junto ao Departamento de Engenharia Rural da ESALQ/USP, durante o período de 02 de agosto a 10 de setembro de 2004.

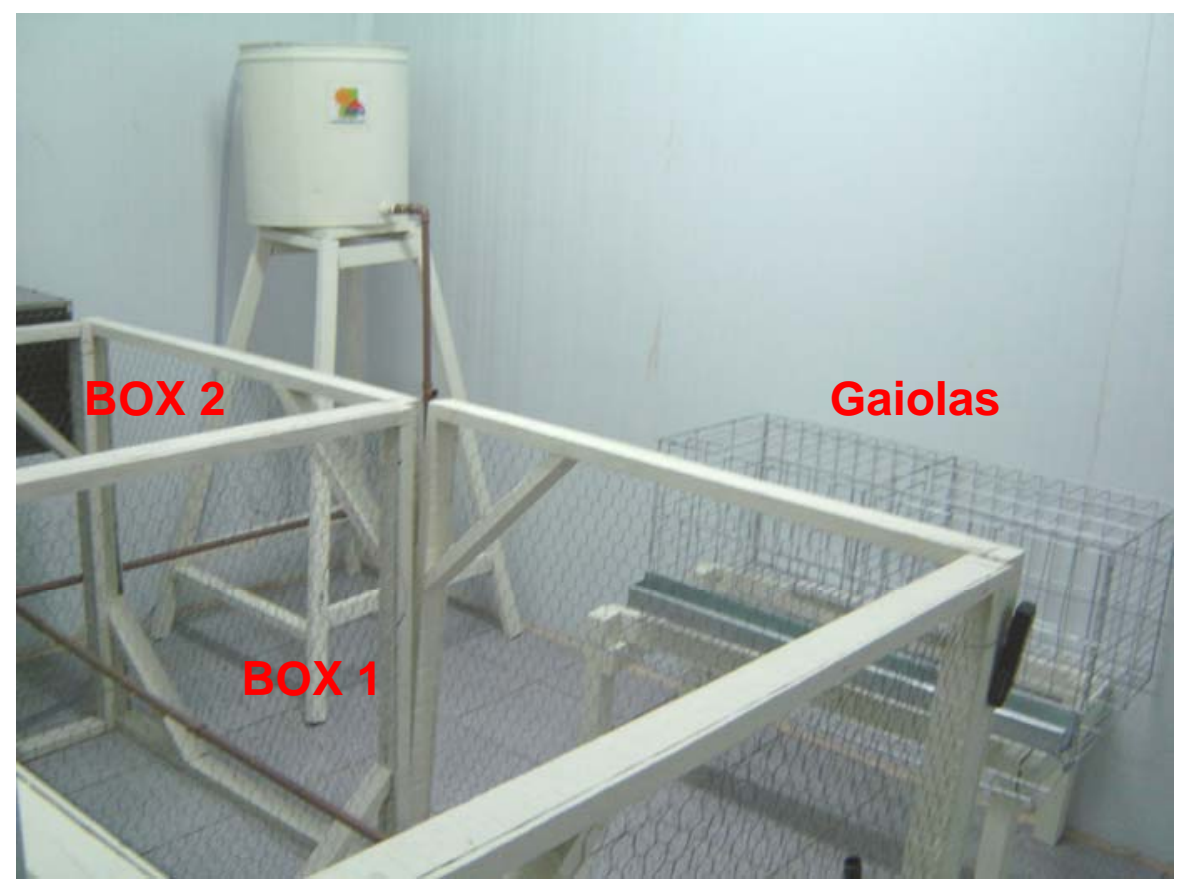

Figura 1 - Divisão da câmara climática em dois boxes e uma bateria de gaiolas

De acordo com a Figura 1, a câmara climática utilizada no experimento tinha dimensões de $3,85 \mathrm{~m}$ de comprimento por $2,35 \mathrm{~m}$ de largura e 2,90m de altura (pédireito), com área de aproximadamente de $9 \mathrm{~m}^{2}$. No interior da câmara foram montados 
dois boxes de $1 \mathrm{~m}^{2}$ cada, contendo ninho e poleiro. Também foi colocado um sistema convencional de gaiolas para a posterior comparação com o sistema "cama+ninho".

As respectivas dimensões da câmara climática podem ser observadas na figura abaixo.
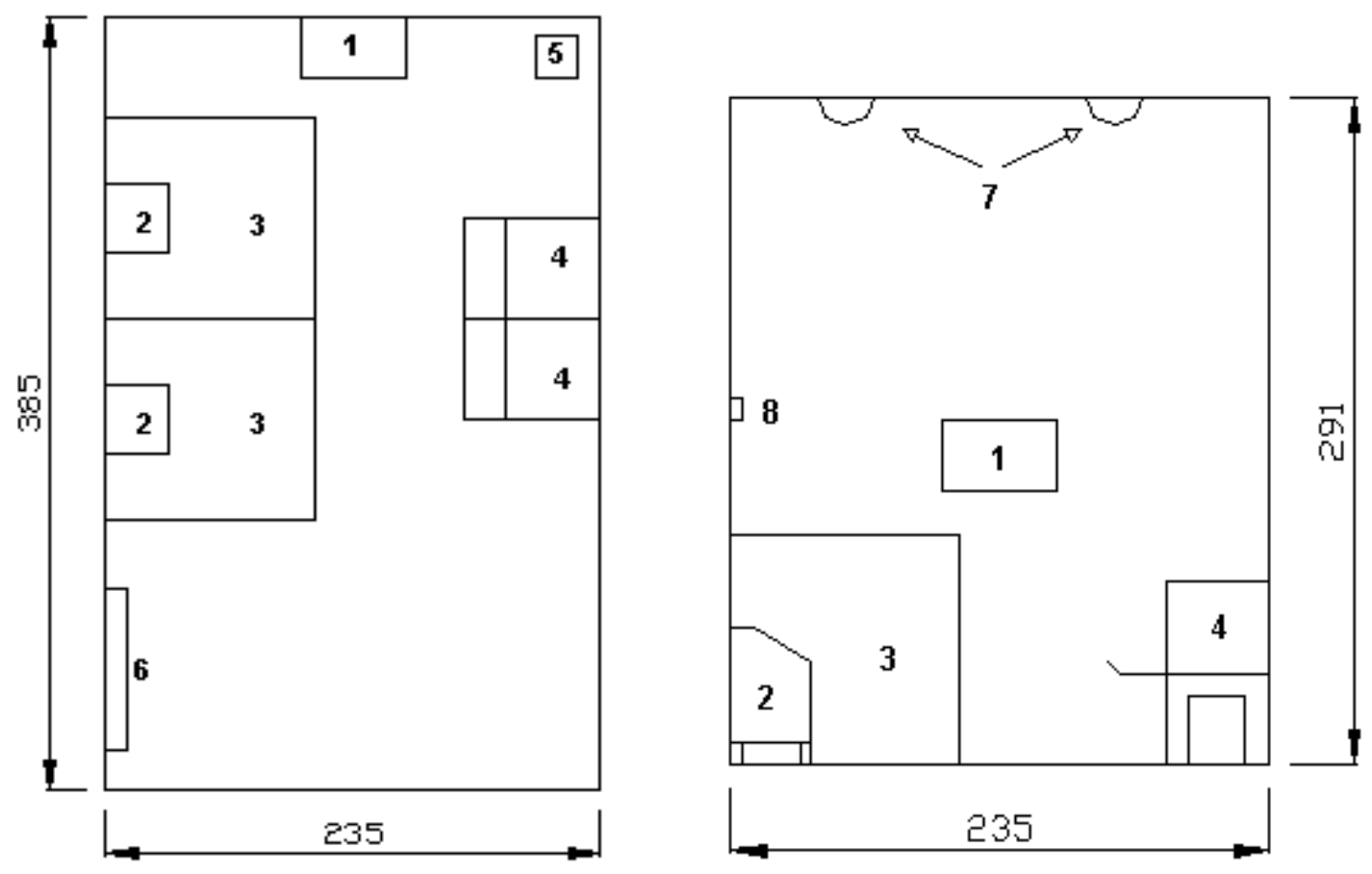

Figura 2 - Croqui da vista horizontal e vertical da câmara climática, onde: 1- Sistema de controle do ambiente, 2- Ninhos, 3- Box com cama, 4- Sistema de gaiolas, 5- Reservatórios de água, 6- Porta da câmara, 7- Câmeras de vídeo, 8- Sensores de temperatura e Umidade

\subsection{Animais}

Foram utilizadas 40 aves de postura, 20 da linhagem Hy-Line W36 (ovos brancos) e 20 da linhagem Hy-Line Brown (ovos vermelhos), com idade de 21 semanas.

Para cada condição de ambiente, conforto e estresse, 10 aves de cada linhagem foram separadas em dois tipos de sistemas de criação, sendo 
respectivamente, 05 aves colocadas no sistema de criação em gaiola e 05 aves no sistema "cama+ninho".

Para que todas as aves fossem avaliadas com a mesma idade nos tratamentos de conforto e estresse térmico, foram adquiridas com uma diferença de idade de 21 dias, ou seja, 20 aves foram compradas com 17 semanas e 20 aves com 20 semanas, uma vez que o período experimental era de 3 semanas ( 1 de adaptação e 2 de coleta de dados), para cada condição ambiental proposta.

\subsection{Fotoperíodo}

Durante a realização da pesquisa foi adotado um fotoperíodo dentro da câmara climática, de 16 horas de luz e 8 horas de escuro (16L:8E).

\subsection{Mortalidade}

Foi contabilizado durante todo o período da pesquisa o número de aves que morreram, bem como o local de morte ("cama+ninho" e gaiolas) e a condição ambiental em que ocorreu a morte.

\subsection{Tratamentos}

\subsubsection{Exposição das aves ao ambiente controlado (câmara climática):}

As aves de cada linhagem e de cada sistema de criação foram expostas a duas condições ambientais, uma condição de conforto térmico e outra de estresse térmico, conforme os tratamentos abaixo:

Tratamento A1 - Exposição a um ambiente com temperatura de $26^{\circ} \mathrm{C} \pm 2^{\circ} \mathrm{C}$ e $60 \% \pm$ $2 \%$ de umidade relativa. (condição de conforto térmico);

Tratamento A2 - Exposição a um ambiente com temperatura de $35^{\circ} \mathrm{C} \pm 2^{\circ} \mathrm{C}$ e $70 \% \pm$ $2 \%$ de umidade relativa. (condição de estresse térmico). 
Todas as aves foram expostas a cada uma das condições ambientais durante 14 dias consecutivos, em ambiente controlado, de acordo com Sevegnani et al. (2001b). Porém, com um período de adaptação gradativa ao ambiente, totalizando 21 dias de exposição ao ambiente controlado para cada tratamento.

\subsubsection{Sistemas de criação:}

As aves foram submetidas a dois tipos de sistemas de criação, que foram comparados para a avaliação do seu bem-estar e da qualidade de sua produção.

Tratamento C1 - Sistema de criação com cama e ninho;

Tratamento C2 - Sistema de criação em gaiolas.

\subsubsection{Caracterização dos sistemas de criação}

Com base nas normas e conceitos de bem-estar animal para aves de postura, a União Européia pretende, por meio de suas diretivas, banir o uso de gaiolas convencionais para a criação de aves de postura até o ano de 2012. (Comissão Européia, 1999), sendo que, após este período, só poderão ser utilizados sistemas de criação que favoreçam o bem-estar dos animais, tais como o uso de gaiolas modificadas ou enriquecidas ou o sistema de semiconfinamento.

São também exigências da norma Européia que cada ave deverá dispor de pelo menos $550 \mathrm{~cm}^{2}$ de superfície de área de gaiola, além de uma área com poleiro, cama para ciscar e ninho.

As figuras abaixo mostram as dimensões do sistema de gaiolas e dos ninhos no sistema com cama adotados nesta pesquisa. 

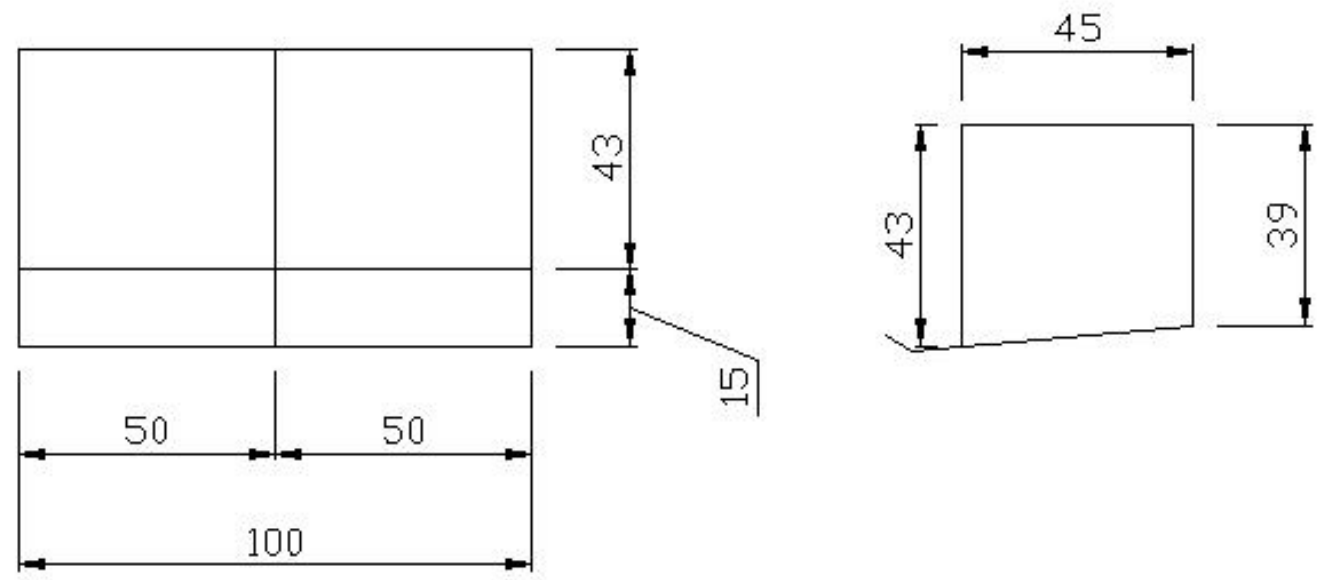

Figura 3 - Dimensões das gaiolas $(\mathrm{cm})$, planta baixa e corte transversal
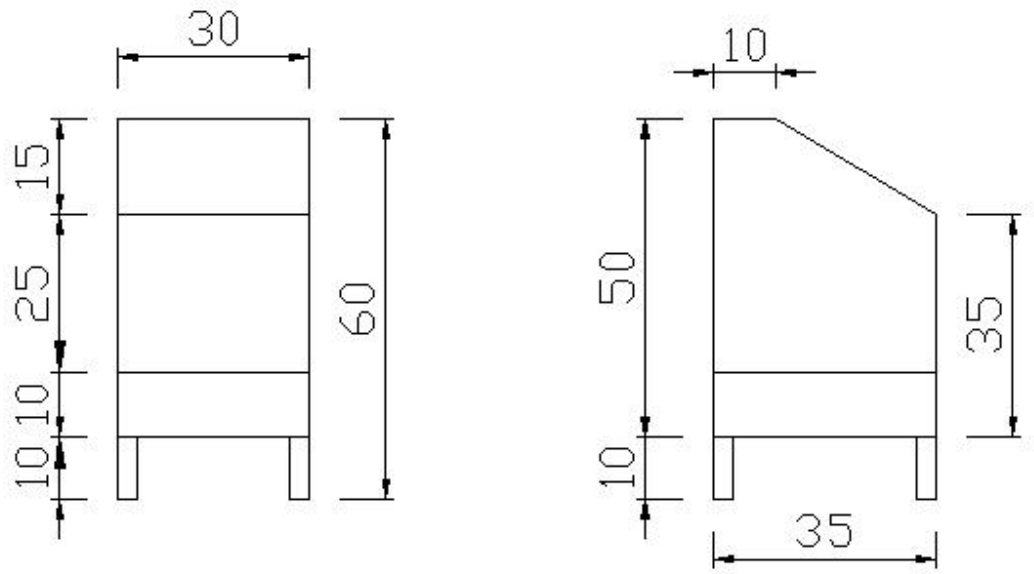

Figura 4 - Dimensões dos ninhos $(\mathrm{cm})$, planta baixa e corte transversal

A gaiola utilizada na pesquisa foi uma gaiola comum (tipo comercial), sem nenhum enriquecimento, ou seja, sem a presença de área com cama, de poleiro ou de ninho. Já o sistema de criação em cama, além da presença desta, possuía ainda ninho e poleiro para as aves, constituindo um ambiente considerado como ideal para a criação das aves com vistas às exigências de bem-estar animal da União Européia.

Na tabela 01 abaixo são apresentas as características dos dois sistemas de criação: 
Tabela 1. Caracterização dos sistemas de criação em cama e em gaiola

\begin{tabular}{lc}
\hline Dimens. Gaiola (comp. x largua x altura) - cm & $50 \times 45 \times 40$ \\
Dimens. Box c/ Cama - cm & $100 \times 100 \times 120$ \\
$N^{\circ}$ aves p/ Box ou Gaiola & 5 \\
Área de Gaiola p/ ave $\left(\mathrm{cm}^{2}\right)$ & 450 \\
Área de Cama p/ ave $\left(\mathrm{cm}^{2}\right)$ & 2000 \\
Poleiro (cm/ave) - somente nos boxes & 20 \\
$\mathrm{~N}^{\circ}$ bebedouros tipo Nipple p/ Gaiola e Box & 2 \\
$\mathrm{~N}^{\circ}$ de ninhos por Box & 1 \\
\hline
\end{tabular}

\subsection{Parâmetros avaliados}

\subsubsection{Parâmetros climáticos}

Os valores de temperatura de bulbo seco (Tbs), umidade relativa (UR) e temperatura de ponto de orvalho (Tpo) foram coletados no interior da câmara climática por meio de miniestações meteorológicas e data logger $\mathrm{HOBO}^{\circledR}$. As miniestações meteorológicas foram instaladas respectivamente a 1,70, 1,50 e a 0,50 m de altura com relação ao piso da câmara, e as leituras foram realizadas a cada 15 min ao longo das $24 \mathrm{~h}$, o que possibilitou traçar um perfil de temperatura dentro da câmara climática, levando-se em consideração a posição do sistema de circulação do ar e a localização dos tratamentos (cama e gaiola), bem como o calculo dos índices de conforto térmico.
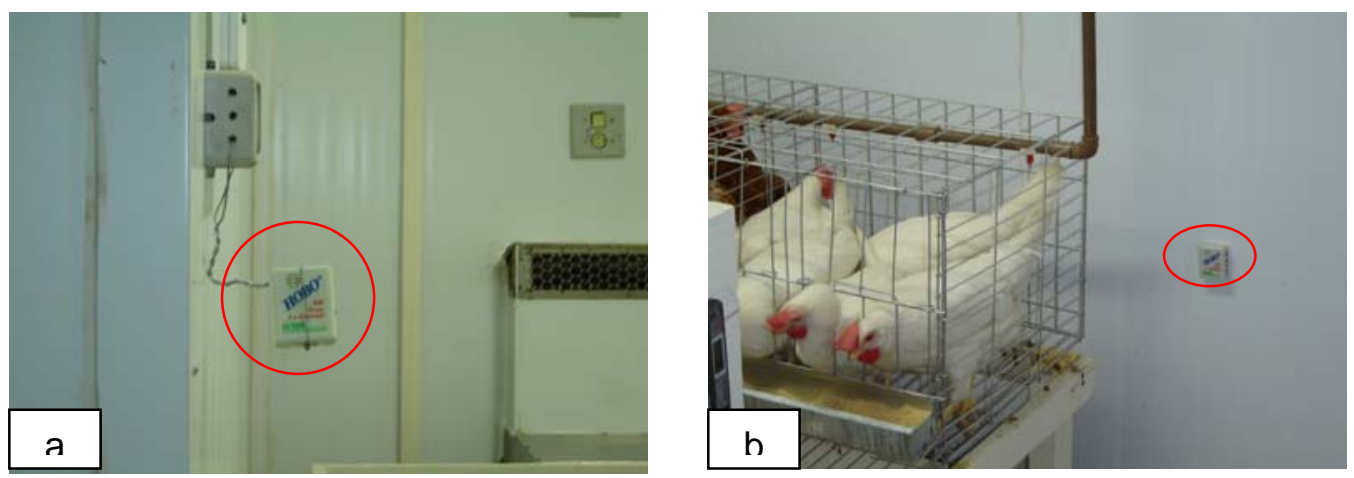

Figura 5 - Detalhe de duas miniestações meteorológicas instaladas respectivamente a 1,70m (a) e 0,5m (b) de altura com relação ao piso da câmara climática 
Nota-se pela Figura 5 que a miniestação meteorológica instalada a $0,5 \mathrm{~m}$ do chão encontra-se bem à altura das aves criadas no sistema de gaiolas. Isto permitiu uma melhor avaliação das condições de temperatura e umidade relativa a que estas aves estavam sendo submetidas, uma vez que, como se sabe, aves criadas neste sistema de confinamento são mais susceptíveis às condições de estresse.

Com os valores dos parâmetros climáticos, puderam então ser calculados os índices de conforto térmico.

\subsection{2 Índices de conforto térmico}

Foram desenvolvidos, para caracterizar ou quantificar as zonas de conforto térmico adequadas às diferentes espécies animais, apresentando em uma única variável, tanto os fatores que caracterizam o ambiente térmico que circunda o animal, como o estresse que tal ambiente possa estar causando no mesmo.

\subsubsection{1 Índice de Temperatura e Umidade (THI) (Thom, 1959)}

Desenvolvido inicialmente para humanos, e utilizado para outros animais, é um índice que engloba os efeitos combinados de temperatura de bulbo seco e úmido. De acordo com Buffington et al. (1981), este índice de conforto é o mais comum existente e mais utilizado.

A equação para o cálculo deste índice é dada por:

$$
\mathrm{THI}=\mathrm{Tbs}+0,36 \mathrm{Tpo}+41,7
$$

em que:

Tbs - temperatura de bulbo seco, ${ }^{\circ} \mathrm{C}$;

Tpo - temperatura de ponto de orvalho, ${ }^{\circ} \mathrm{C}$. 


\subsubsection{Entalpia}

Entalpia, por definição, é a energia do ar úmido por unidade de massa de ar seco ( $\mathrm{kJ} / \mathrm{kg}$ de ar seco), ou seja, é uma variável física que indica a quantidade de energia contida em uma mistura de vapor d'água. Portanto, nos casos de alteração na umidade relativa, para uma mesma temperatura, a energia envolvida nesse processo se altera, e como conseqüência, as trocas térmicas no ambiente serão alteradas.

A equação para o cálculo da entalpia foi descrita por Villa Nova (1999), citado por Furlan (2001), como:

$$
\mathrm{H}=6,7+0,243 \times \mathrm{tbs}+\left\{\mathrm{UR} / 100 \times 10^{\wedge}[(7,5 \times \mathrm{tbs}) /(237,3+\mathrm{tbs})]\right\}
$$

onde:

$\mathrm{H}=$ entalpia (kcal/kg ar seco);

tbs = temperatura ambiente (bulbo seco) $\left({ }^{\circ} \mathrm{C}\right)$;

$\mathrm{UR}=$ umidade relativa do $\operatorname{ar}(\%)$.

\subsubsection{Parâmetros fisiológicos}

Os dados fisiológicos foram analisados para todas as aves. Registrou-se :

Temperatura retal (TR) - Termômetro inserido no reto por, no mínimo, 2 minutos, medida uma vez por semana para cada condição ambiental às 14:00h;

Freqüência respiratória (FR) - Contagem dos movimentos de ofegação durante 15 segundos, realizada uma vez por semana para cada condição ambiental às 14:00h, de acordo com a metodologia utilizada por Harrison e Biellier, (1968).

\subsubsection{Parâmetros comportamentais}

Para a análise do comportamento, todas as aves foram identificadas através de um sistema de marcação individual (pintura do dorso com tinta não tóxica), Rudkin \& Stewart (2003), o que possibilitou o acompanhamento e análise dos comportamentos de cada ave. 


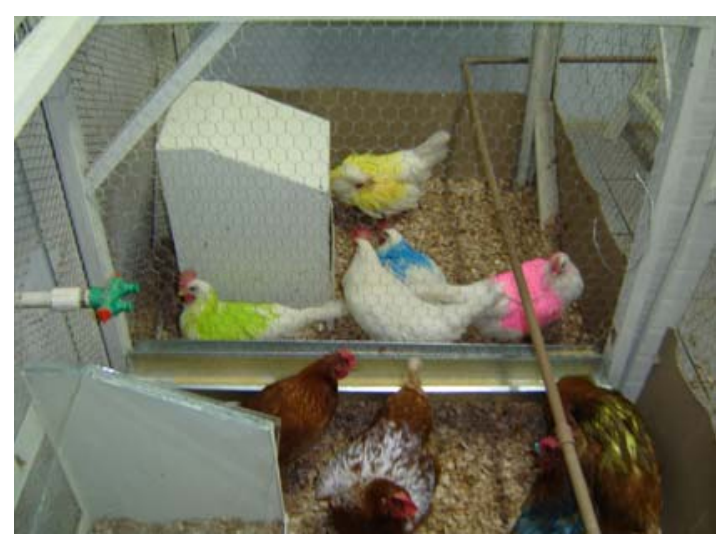

Figura 6 - Sistema de marcação individual para a análise de imagens por meio da pintura do dorso das aves

As imagens foram registradas por câmeras de vídeo instaladas no teto da câmara climática que, por sua vez, eram ligadas a um microcomputador equipado com placa de captura de imagens e software para a análise, (Figuras 7 a e b).
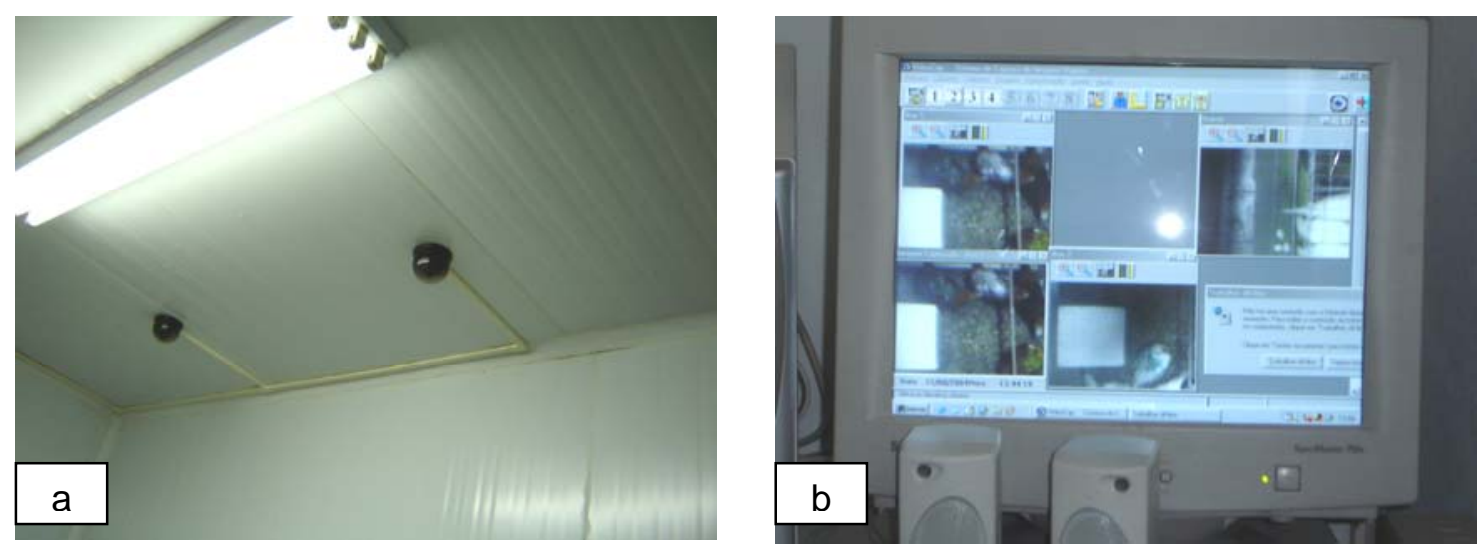

Figura 7 - Câmeras de vídeo instaladas no teto da câmara climática (a) e tela do computador equipado com placa de captura e software para imagens (b)

As imagens foram registradas a cada segundo por um período de 1 hora na parte da manhã (das 10:00 às 11:00h) e 2 horas na parte da tarde (das 13:00 às 14:00h e das 16:00 às 17:00h), durante dois dias consecutivos, para cada condição de ambiente e sistema de criação proposto. As imagens, gravadas a cada segundo, foram gerenciadas pelo software "VIDEOCAP 5.1", sendo armazenadas em um banco de dados. Durante o período da noite, não foram registrados dados de comportamento. 
Após o período de coleta de imagens, estas foram então analisadas pelo método visual, ou seja, sem o auxilio de softwares de interpretação ou de análise de imagens. Sendo então, as imagens, analisadas para cada ave, cada comportamento e para cada período do dia, sempre pela mesma pessoa.

Após as analises, foram então calculados as porcentagens de tempo de expressão de cada comportamento, bem como o período em minutos e segundos de duração de cada comportamento.

Os padrões comportamentais foram avaliados de acordo com Rudkin \& Stewart (2003), levando-se em consideração as atividades desenvolvidas por cada ave.

Foram avaliados os seguintes padrões comportamentais:

a) Comendo - Quando a ave está se alimentando, comportamento caracterizado geralmente quando a ave se encontra com a cabeça no comedouro.

b) Bebendo - Quando a ave está bebendo água, geralmente caracterizado quando a ave está bicando o bebedouro tipo Nipple.

c) Investigando penas - Comportamento não agressivo, caracterizado quando a ave investiga suas próprias penas com o bico ou investiga as penas de outras aves.

d) Banho de areia - Comportamento característico das aves, envolve em sua caracterização uma seqüência de ciscar e jogar "areia" sobre seu corpo, além de movimentos rápidos de chacoalhar as penas.

e) Movimentos de conforto - São considerados comportamentos apresentados pelas aves, quando estas se encontram em condição de conforto e bem-estar. São considerados como movimentos de conforto comportamentos como: bater e esticas as asas e chacoalhar as penas.

f) Ciscando - Outro comportamento considerado como característico das aves, caracterizado quando a ave explora seu território com seus pés e bico.

g) Empoleirar - Comportamento muito associado ao bem-estar das aves, por ser um comportamento natural. É caracterizado, quando a ave sobe em algum aparato que se encontra acima do nível do solo.

h) Agressividade - Comportamento relacionado à condição de estabelecer dominância no grupo ou a condições de estresse, sendo geralmente 
caracterizado por bicadas rápidas e fortes em locais como a crista e outras partes da cabeça.

i) Sentada - Comportamento caracterizado quando a ave senta na cama ou substrato em que se encontra.

j) Procurando ninho - Comportamento considerado como de pré-postura, é facilmente detectável e caracterizado como entradas rápidas e freqüentes ao ninho, como numa tentativa de avaliar o local antes de botar os ovos.

k) Postura - Caracterizado como a presença da ave sentada no ninho e com a comprovação da presença do ovo.

l) Parada - Comportamento caracterizado quando a ave não apresenta nenhum movimento, ou aparentemente não se enquadra em nenhum dos comportamentos anteriores.

\subsubsection{Sistema de marcação das aves}

O sistema de marcação através da pintura do dorso das aves com tinta não tóxica se mostrou como a melhor maneira de se identificar individualmente cada ave durante a análise de imagens. Este sistema de marcação, foi escolhido pois em comparação com outros tipos de marcação, tais como, cordões coloridos nos pés, pintura da crista ou ainda números tatuados no dorso, não foram eficientes em identificar os animais em testes preliminares executados antes do início do experimento.

Por serem animais muito curiosos, as aves tinham uma tendência de perder ou arrancar os marcadores, no caso de cordões coloridos nos pés, ou ainda, de apresentarem um comportamento agressivo diante de outras aves com a crista pintada, isso seria explicado, talvez, pelo importante papel que a crista tem na identificação dos animais. Rudikin \& Stewart, (2003).

Outro ponto que foi analisado na escolha do sistema de marcação das aves, foi quanto a eficiência relacionada à visibilidade da marcação na imagem que era capturada pelas câmeras de vídeo no teto da câmara climática, uma vez que, devido ao posicionamento das câmeras, marcações como as feitas pelos pés, não apareciam nas imagens capturadas, ou o sistema de marcação com números ou letras pintadas 
no dorso, com o passar do tempo, começavam a desaparecer, principalmente pela ação do comportamento de investigar penas.

Sendo assim, foi então adotado o sistema de pintura do dorso das aves com tinta não tóxica e de diferentes cores (claras para aves marrons e escuras para aves brancas), aparentemente não foi verificado nenhum problema quanto a este tipo de marcação nas aves, tanto do ponto de vista comportamental (agressividade), quanto do ponto de vista sanitário.

As aves eram pintadas assim que iniciavam seu período de adaptação em câmara climática e foi constatada também a importância deste período para que as aves se habituassem a este sistema de marcação.

\subsubsection{Consumo de água e ração}

O consumo de água foi medido diariamente e durante todo o período experimental, para cada condição ambiental e sistema de criação, por meio da medida da diferença de nível da água nos respectivos reservatórios.

Foi medida também a temperatura da água, uma vez que, segundo Macari (1995), o consumo de água tende a diminuir, quando a temperatura da água aumenta.

O consumo de ração foi medido diariamente e durante todo o período experimental, por meio da pesagem das sobras de ração nos comedores, que eram então subtraídas do total de ração fornecido às aves.

A quantidade de ração fornecida às aves, seguiu o especificado para cada linhagem de acordo com a idade, conforme o que consta no guia de manejo da Hy-Line W36 e Hy-Line Brown, que foram respectivamente: $92 \mathrm{~g} / \mathrm{ave} / \mathrm{dia}$ para a linhagem HyLine W36 e 113 g/ave/dia para a linhagem Hy-Line Brown.

\subsubsection{Níveis de Amônia}

A qualidade do ar com relação às concentrações de amônia dentro da câmara climática para as duas condições de ambiente propostas, foi medida com o auxilio de um aparelho medidor de gases portátil (Commander XP - IST-AIM), durante 7 dias consecutivos pra cada condição ambiental avaliada. 


\subsection{Parâmetros de qualidade dos ovos}

\subsubsection{Peso do ovo}

Para toda a produção de ovos, durante a pesquisa, foi feita a determinação do peso dos ovos (g). Para isso utilizou-se uma balança analítica (modelo Gehaka BG 2000), com divisão de $0,01 \mathrm{~g}$, sendo o peso dos ovos um valor de referência para o posterior cálculo das porcentagens de cada fração do ovo.

\subsubsection{Gravidade especifica}

A medida da gravidade específica do ovo é provavelmente uma das técnicas mais comumente usadas para determinar a qualidade da casca do ovo, devido a sua rapidez, praticidade e baixo custo. A técnica baseia-se no princípio da flutuação, sendo os ovos imersos em recipientes contendo soluções salinas em ordem crescente de densidade. Considera-se a densidade do ovo a solução na qual ele flutua, Hamilton (1982).

A gravidade específica foi determinada pelo método das soluções gradualmente salinas. Este método consiste na imersão dos ovos em diferentes soluções salinas, com densidades que variam de 1,0650 a 1,0950 com aumento de 0,0025.

De acordo com a metodologia proposta por Voisey \& Hunt (1974), os ovos devem ser colocados em recipientes com soluções salinas, da menor para maior concentração, e devem ser retirados ao flutuarem, anotando-se, assim, o valor respectivo de densidade correspondente à solução do recipiente.

Conforme sugerido também por Voisey \& Hunt (1974), a gravidade específica deverá ser medida de preferência logo após a postura do ovo, sendo que ovos trincados não deverão ser testados.

Na Figura 8, tem-se o sistema de recipientes (baldes) com diferentes soluções salinas utilizadas para a avaliação da gravidade específica. 

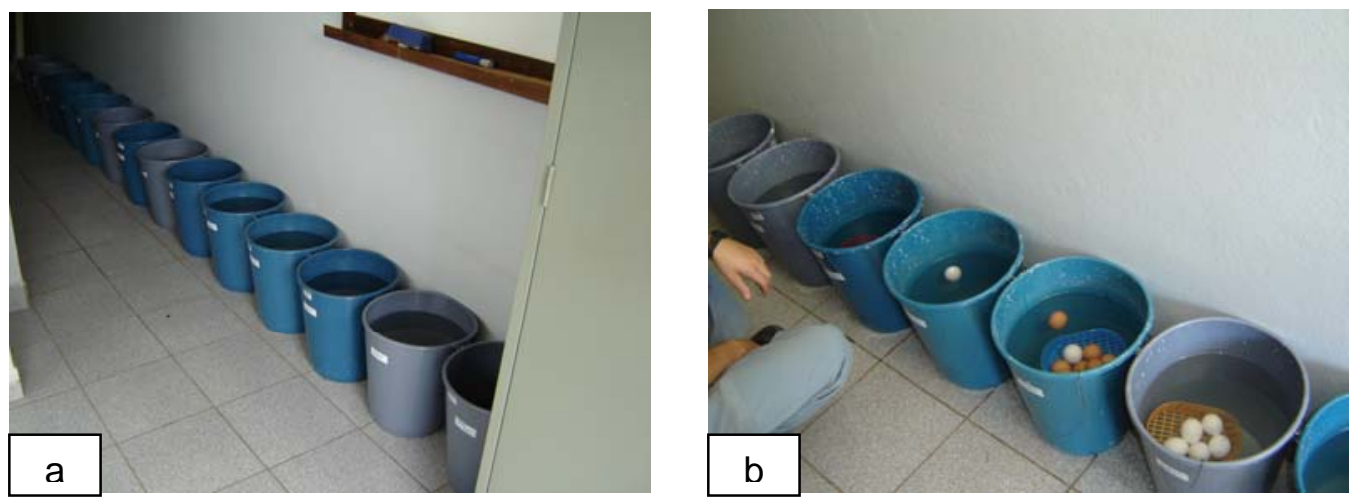

Figura 8 - Recipientes com as soluções salinas (a) e ovos sendo avaliados (b)

\subsubsection{Unidade Haugh}

Após a pesagem dos ovos, estes foram quebrados e seu conteúdo, (clara+gema), colocado numa superfície de vidro plana e nivelada. Mediu-se então a altura do albúmen $(\mathrm{mm})$, por meio da leitura do valor indicado pelo micrômetro tripé modelo AMES S-6428. De posse dos valores de peso do ovo (g) e altura do albúmen (mm), utilizou-se então a fórmula descrita por Pardi (1977), para o calculo da unidade Haugh:

$$
\begin{aligned}
& \mathrm{UH}=100 \log \left(\mathrm{h}+7,57-1,7 \mathrm{~W}^{0,37}\right), \text { onde: } \\
& \mathrm{h}=\text { altura do albúmen }(\mathrm{mm}) \\
& \mathrm{W}=\text { peso do ovo }(\mathrm{g})
\end{aligned}
$$

Quanto maior o valor da UH, melhor será a qualidade dos ovos, que são classificados segundo o USDA em ovos tipo AA (100 até 72), A (71 até 60), B (59 até 30), C (29 até 0), USDA Egg-Grading Manual (2000).

Na Figura 9, pode-se observar a condição de realização da medida da altura do albúmen pelo micrômetro tripé. 

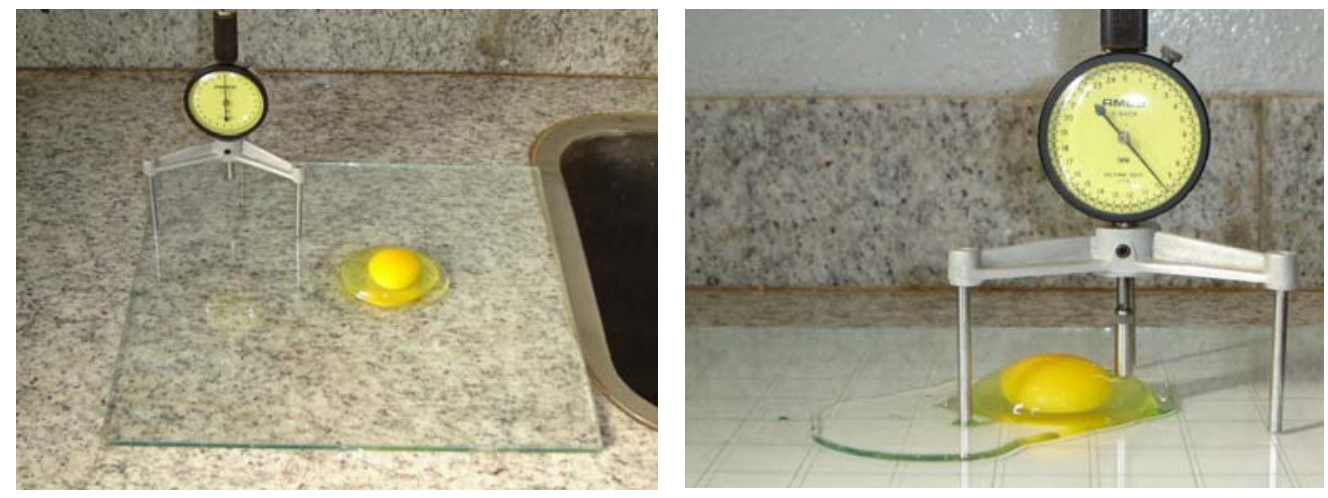

Figura 9 - Avaliação da unidade "Haugh" dos ovos

\subsection{4 Índice de gema}

Após a medida da altura do albúmen $(\mathrm{mm})$, separou-se a clara da gema do ovo e, colocando-a novamente sobre a superfície plana de vidro, mediu-se com o mesmo micrômetro utilizado anteriormente a altura da gema $(\mathrm{mm})$. O próximo passo então foi medir o diâmetro da gema $(\mathrm{mm})$, para isso foi utilizado um paquímetro.

Daí então o índice de gema foi obtido dividindo-se a altura da gema pelo valor do seu respectivo diâmetro, sendo considerados normais, valores entre 0,3 a 0,5.

$\mathrm{Na}$ Figura 10, observa-se a medida da altura e do diâmetro da gema respectivamente.
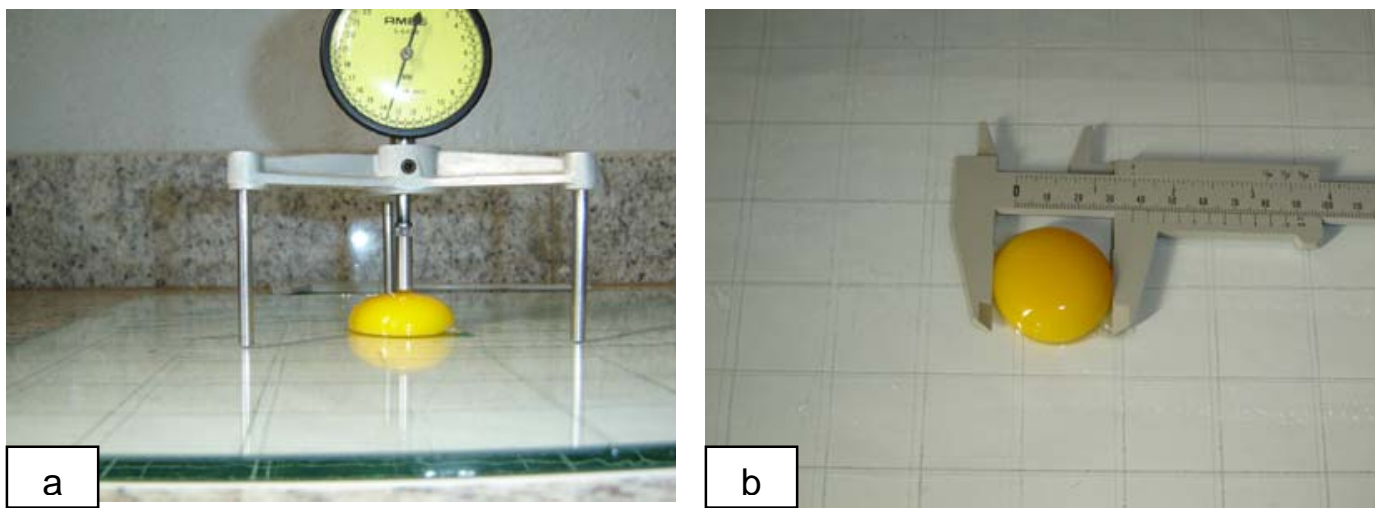

Figura 10 - Medida da altura da gema $(\mathrm{mm})$ com micrômetro (a) e do diâmetro da gema (mm) com paquímetro (b) 


\subsubsection{Porcentagem de constituintes}

As porcentagens de gema, albúmen e casca, foram obtidas pela pesagem ( $\mathrm{g}$ ) em balança analítica, de cada uma das partes, sendo que este peso foi então dividido pelo peso do ovo (g) e multiplicado por 100, para a obtenção das porcentagens de cada constituinte.

\subsubsection{Espessura da casca}

A medida da espessura da casca dos ovos foi realizada sem a remoção das membranas internas da casca. Para sua determinação foi utilizado o micrômetro de precisão para medidas de espessuras Mitutoyo Dial Thickness Gage, com divisões de $0,01 \mathrm{~mm}$.

Após os ovos serem quebrados, as cascas eram cuidadosamente lavadas em água corrente para a retirada dos restos de albúmem que ainda permaneciam em seu interior. Depois de lavadas, as cascas foram colocadas em um suporte e deixadas para secar de um dia para o outro, à temperatura ambiente. Depois de devidamente secas, estas eram então medidas em 3 pontos distintos na área centro-transversal para a obtenção da média da espessura.

Na Figura 11, é mostrado o micrômetro para as medidas de espessura e uma medição da espessura da casca sendo feita.
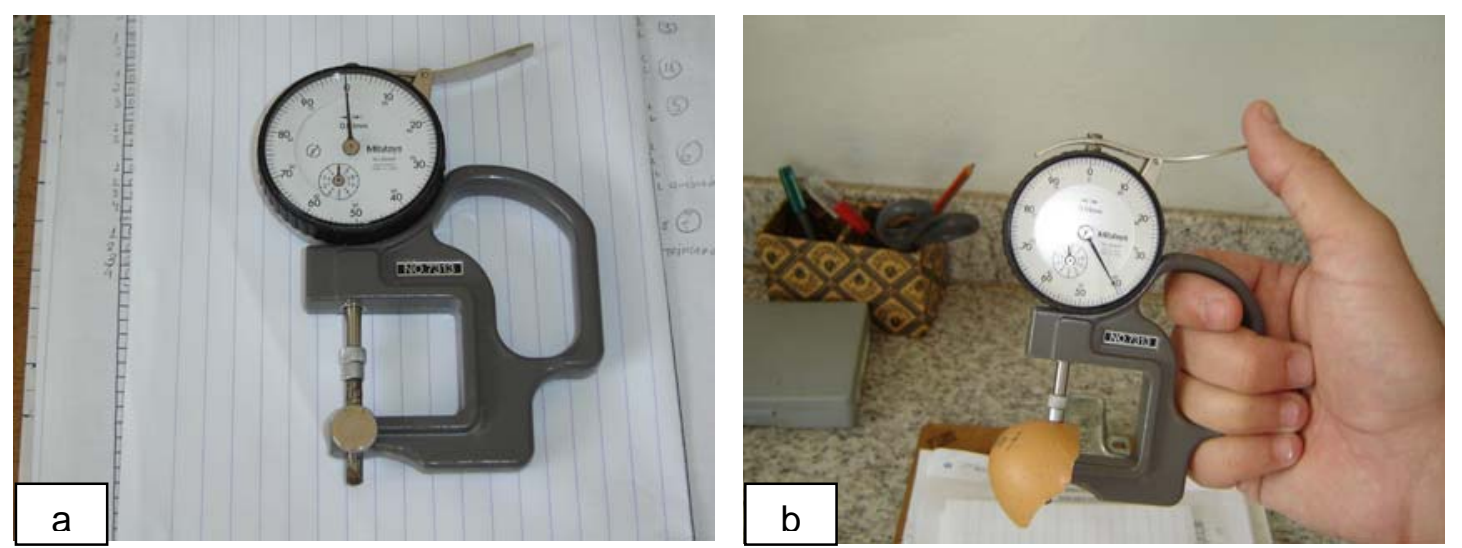

Figura 11 - Micrômetro de precisão para medidas de espessura (a) e medida da espessura (mm) da casca (b) 


\subsubsection{Porosidade da casca}

A concentração de poros na casca dos ovos foi medida de acordo com a metodologia sugerida por Peebles \& Brake (1985).

Primeiramente, a casca do ovo foi lavada para a retirada de qualquer resíduo ou sujeira, e depois colocada em contato com um corante $(0,5 \mathrm{~g}$ de metileno a $89 \%+1$ litro de etanol a 70\%). Após esperar um tempo de aproximadamente 30 min para que o corante penetrasse nos poros, a casca foi levada ao microscópio e, com o auxilio de um cartão recortado com área de $0,4 \mathrm{~cm}^{2}$, fez-se a contagem dos poros.

A porosidade varia conforme a posição de medida na casca. Segundo Peebles \& Brake (1985), a porosidade é variável para as regiões equatorial, pólo superior e pólo inferior, sendo que neste trabalho só foram contabilizados os poros da região equatorial dos ovos.

\subsubsection{Colorimetria da gema}

Foi analisada com o aparelho colorímetro Minolta Chroma Meter CR-200 b, previamente calibrado em superfície branca, de acordo com padrões préestabelecidos, segundo Bible \& Singha (1993).

Foram avaliados 3 valores do croma: $\mathbf{a}, \mathbf{b}$ e L. O valor de a caracteriza coloração na região do vermelho $(+\mathbf{a})$ ao verde $(-\mathbf{a})$, o valor $\mathbf{b}$ indica coloração no intervalo do amarelo (+b) ao azul (-b) e o valor $\mathbf{L}$ fornece a luminosidade, variando do branco $(\mathbf{L}=100)$ ao preto $(\mathbf{L}=0)$.

\subsubsection{Qualidade visual dos ovos}

Foi realizada uma classificação visual para: ovos sujos, quebrados, trincados e ovos sem casca, em toda a produção durante a pesquisa.

\subsection{Ovoscopia}

Ovoscopia é um processo realizado para se detectar defeitos na casca e no interior dos ovos, por meio de uma luz forte que atravessa o ovo. Tem as vantagens de 
ser uma análise relativamente rápida e não destrutiva dos ovos. Defeitos como trincas e rachaduras na casca, pontos de sangue na gema, posição e integridade da gema e posição e tamanho da câmara de ar, podem ser detectados neste processo.

Para se proceder a ovoscopia dos ovos, se fez necessário a utilização de um aparelho (ovoscópio), que pode ser um equipamento industrial ou construído pelo próprio interessado em analisar os ovos, que proporcione uma luz forte e direcionada, para que, ao colocar o ovo no aparelho, esta luz possa atravessá-lo e revelar a qualidade real da casca e do interior deste.

O ovo em boas condições deve apresentar a casca de cor uniforme, limpa, espessa, pouco porosa e possuir forma normal; seu conteúdo deve apresentar câmara de ar pequena e imóvel, clara homogênea e transparente, gema com aspecto de uma sombra rosada quase transparente e com movimento lento no centro do ovo, tendo contorno pouco visível, Oliveira et al. (2001).

Para a realização da ovoscopia nesta pesquisa, foi utilizado um ovoscópio feito na própria universidade, de acordo com a figura 12 abaixo:
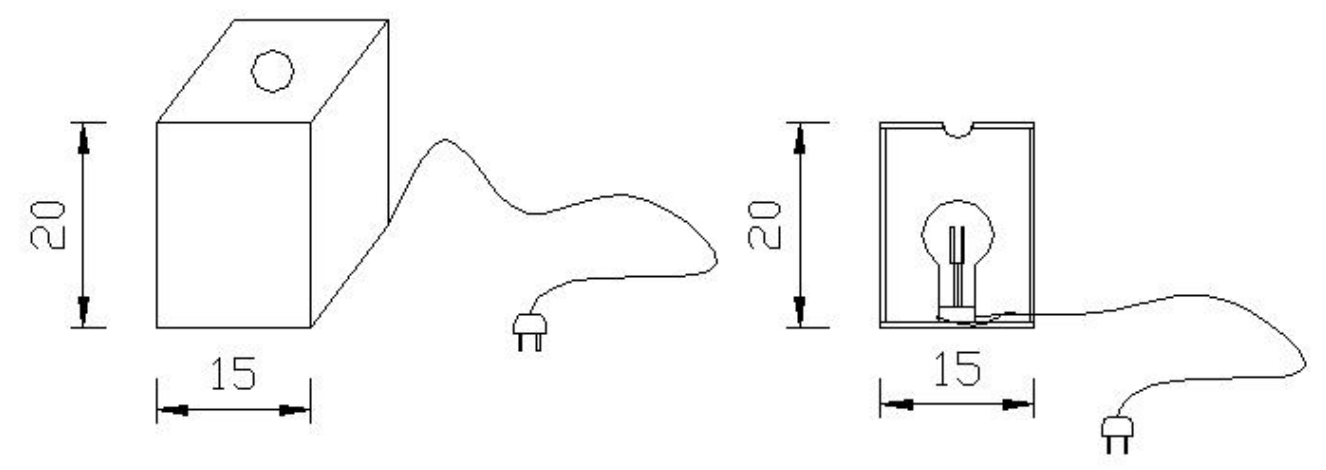

Figura 12 - Esquema do ovoscópio utilizado na pesquisa, dimensões em cm

\subsection{Avaliação Microbiológica}

Quanto à integridade e qualidade dos ovos, foi avaliada a possível presença de Salmonella sp no interior e exterior dos ovos (casca e gema). Também foram avaliados aspectos de contaminação por bolores e leveduras, bem como a presença e quantidade de coliformes fecais e totais. 
Todas as análises foram realizadas pela BIOAGRI Laboratórios Ltda, seguindo a metodologia POP M 252, revisão 04 (2004), Compendium of Methods for the Microbiological Examination of Foods, 1992.

\subsection{Delineamento experimental}

O delineamento experimental adotado foi um esquema fatorial $2 \times 2 \times 2$, sendo 2 sistemas de condicionamento térmico (conforto e estresse) $\times 2$ linhagens de poedeiras (Hy-Line W36 e Hy-Line Brown) e 2 condições de criação ("cama+ninho" e sistema de gaiolas), sendo considerada cada ave uma unidade experimental.

Toda a análise estatística foi realizada pelo pacote estatístico SAS (1992) ${ }^{\circledR}$, e foi utilizado o teste de Tukey $(\mathrm{P}<0,05)$ para a comparação entre as médias, de acordo com a tabela abaixo:

Tabela 2. Análise de variância utilizada

\begin{tabular}{cc}
\hline CV & GL \\
\hline Linhagens (L) & 1 \\
Condições de criação (C) & 1 \\
Condições de ambiente (A) & 1 \\
L x C & 1 \\
L x A & 1 \\
C x A & 1 \\
L x C x A & 1 \\
Resíduo & 32 \\
Total & 39 \\
\hline
\end{tabular}




\section{RESULTADOS E DISCUSSÃO}

\subsection{Parâmetros climáticos}

As Figuras 13 e 14 abaixo mostram as médias de temperatura de bulbo seco (Tbs) e umidade relativa (UR), dentro da câmara climática, durante os períodos de adaptação e coleta de dados, para as duas condições de ambiente propostas (conforto e estresse). O período de adaptação foi de uma semana em cada fase, sendo que as variáveis temperatura e umidade relativa recebiam acréscimos periódicos para que as aves pudessem ir se adaptando às condições de ambiente controlado propostas.

O período de adaptação foi importante também no aspecto de adaptação das aves criadas fora das gaiolas às instalações da câmara climática, tais como a adaptacão a nresenc.a do ninho. noleirn e c.ama

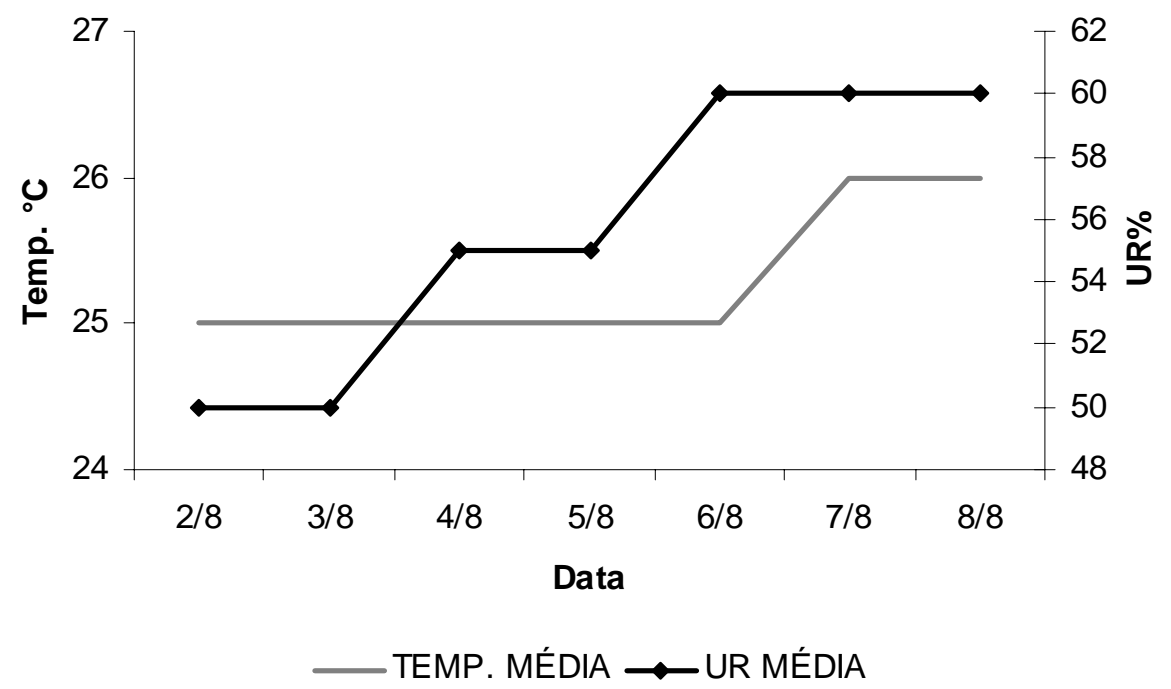

Figura 13 - Médias de temperatura de bulbo seco e umidade relativa, durante o período de adaptação em câmara climática para a condição de conforto 


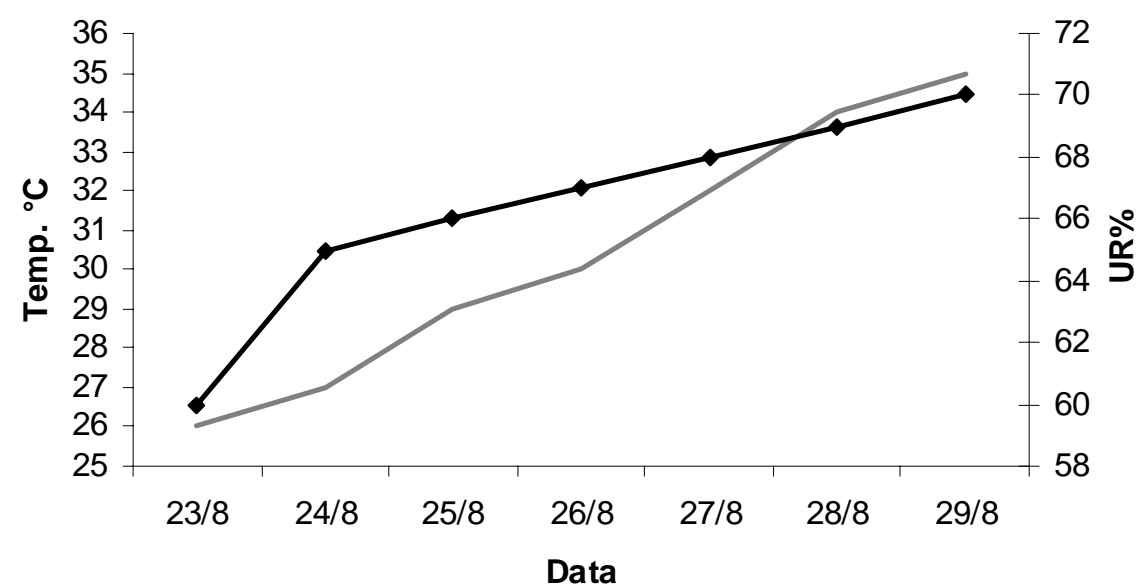

TEMP. MÉDIA ๑UR MÉDIA

Figura 14 - Médias de temperatura de bulbo seco e umidade relativa, durante o período de adaptação em câmara climática para a condição de estresse

Logo após o período de adaptação das aves às condições da câmara, esta foi programada para manter uma condição de $26^{\circ} \mathrm{C} \pm 2{ }^{\circ} \mathrm{C}$ de temperatura e $60 \% \pm 2 \%$ de umidade relativa para a condição de conforto e para a condição de estresse foi programada para manter uma condição de $35^{\circ} \pm 2^{\circ} \mathrm{C}$ de temperatura e $70 \% \pm 2 \%$ de umidade relativa, variando conforme o perfil apresentado pelas figuras 15 e 16 durante o período de registro dos dados.

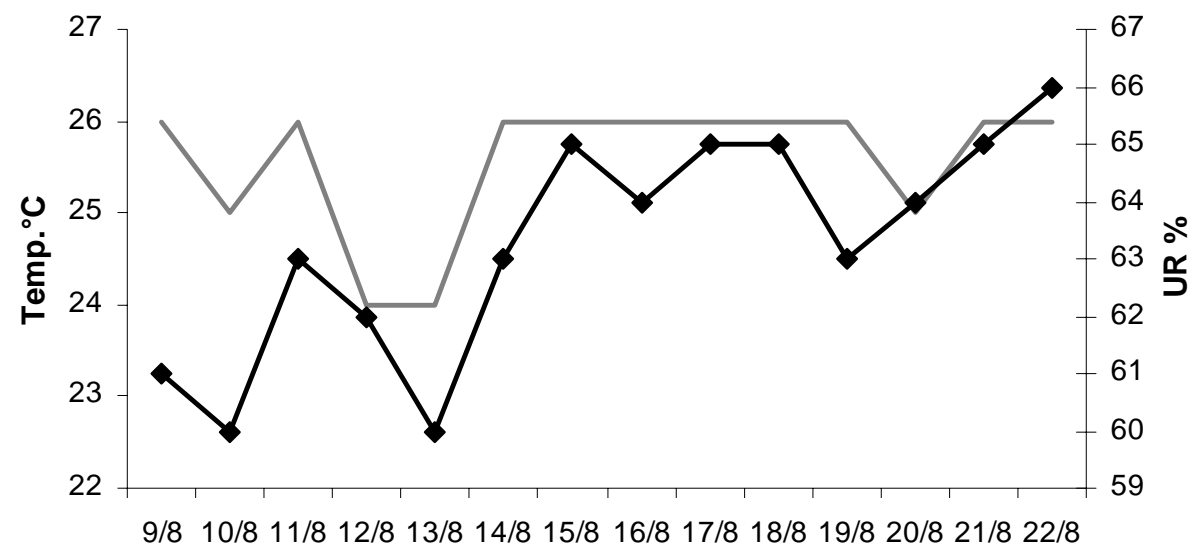

Data

—TEMP. MÉDIA —UR MÉDIA

Figura 15 - Médias de temperatura de bulbo seco e umidade relativa, durante o período de registro de dados em câmara climática para a condição de conforto 


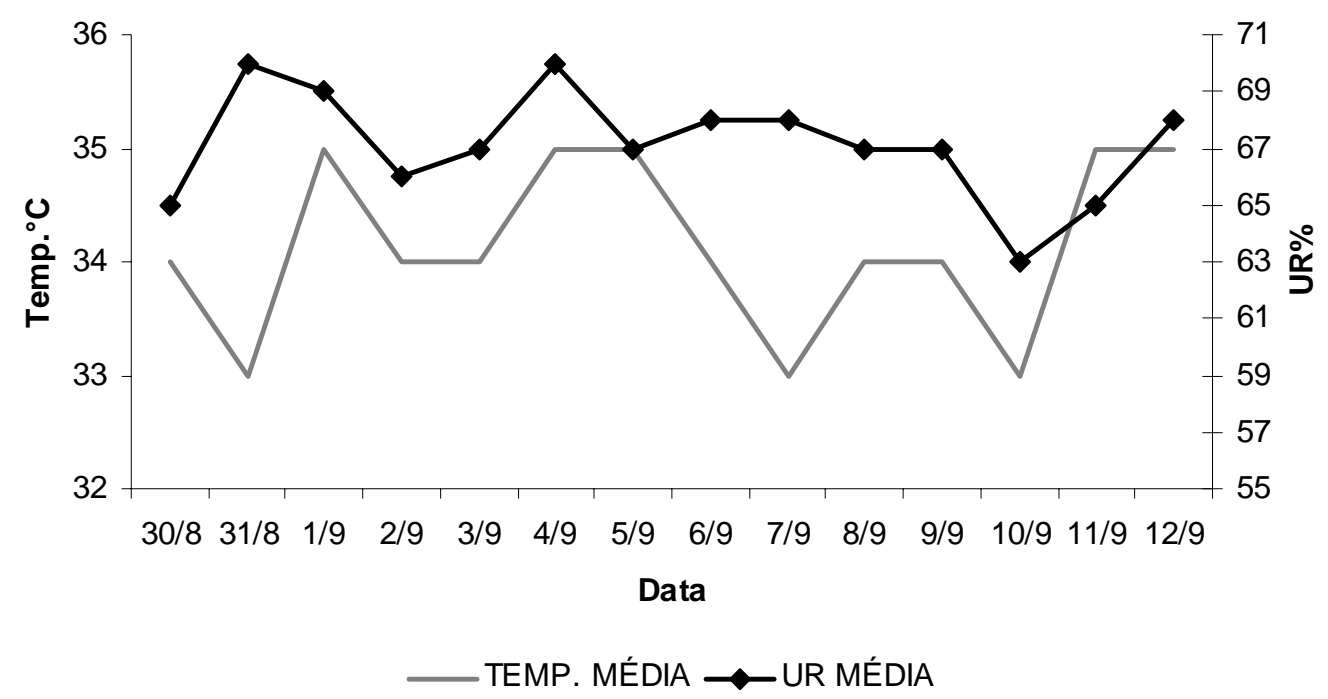

Figura 16 - Médias de temperatura de bulbo seco e umidade relativa, durante o período de registro de dados em câmara climática para a condição de estresse

O que pode ser constatado pelos gráficos das variações das temperaturas e umidades relativas médias, durante os períodos de aquisição de dados, é que, observando-se o comportamento, principalmente da variável umidade relativa, nota-se que no início do período de registro de dados (1 ${ }^{\text {a }}$ semana) os valores de umidade relativa ainda se encontravam dentro da faixa de programação da câmara climática $(60 \% \pm 2 \%$ e $70 \% \pm 2 \%)$, mas assim que se inicia a $2^{\text {a }}$ semana de coleta de dados, esta variável tende a se elevar acima do limite previamente estabelecido, o que indica que, provavelmente, outros fatores dentro da câmara contribuíram para o acréscimo desta variável.

Provavelmente os fatores que estariam contribuindo para o aumento da umidade relativa dentro da câmara climática, estariam relacionados com aumento no volume de fezes por parte das aves, aumento da perda de calor por evaporação (ofegação) e ainda ao umedecimento da cama.

Durante o experimento foi possível comprovar que a variável umidade relativa, mesmo em condições de câmara, é de difícil controle, uma vez que é dependente de vários outros fatores. Já a variável temperatura foi mais fácil de ser controlada e, como pode ser comprovado pelas figuras acima, não houve uma grande variação durante os períodos de aquisição de dados, ficando portanto, dentro dos limites pré-estabelecidos de programação da câmara. 
Diante disso, considerou-se neste estudo, os valores de $26^{\circ} \mathrm{C}$ de temperatura e $63 \%$ UR para a condição de conforto e de $34^{\circ} \mathrm{C}$ de temperatura e $67 \%$ UR para a condição de estresse, de acordo com os valores médios encontrados dentro da câmara climática.

\section{2 Índices de conforto térmico}

Para uma melhor visualização e diferenciação das condições ambientais estudadas, os seguintes indicativos de conforto térmico foram analisados:

\subsection{1 Índice de Temperatura e Umidade (THI)}

As Figuras 17 e 18 abaixo mostram a tendência do índice de temperatura e umidade (THI) para as condições de conforto e estresse térmico, bem como a respectiva faixa com os valores limites considerados como "ideais" para aves.

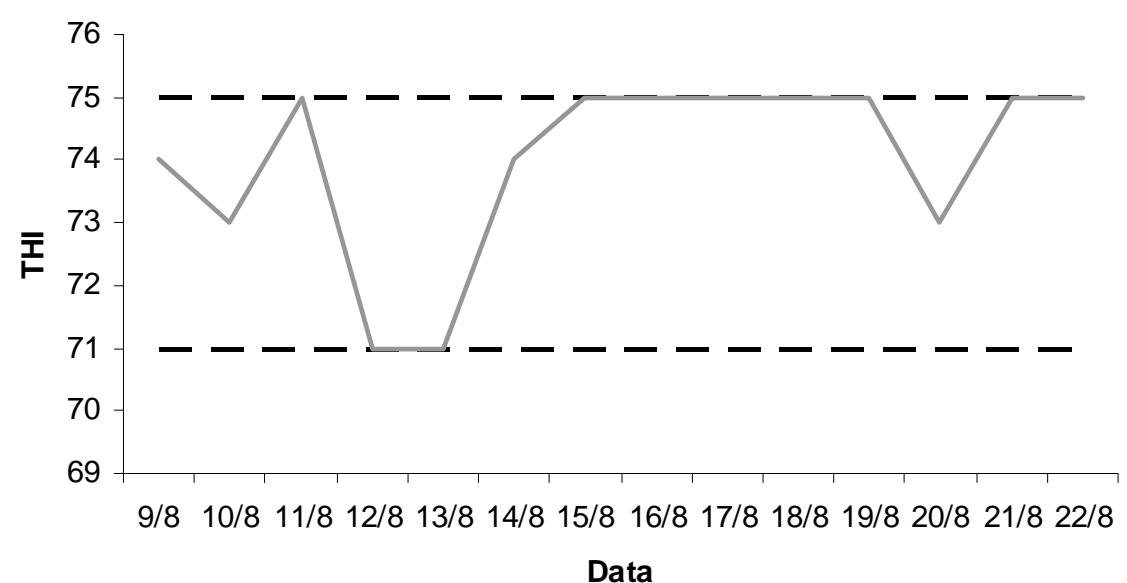

$$
\text { - }- \text { THIconf. Inf. } \_ \text {- THIconf. Sup. — THIreal }
$$

Figura 17 - Valores de THI em câmara climática na condição de conforto (THIreal) e a faixa considerada ideal para aves, com os respectivos limites, inferior e superior de conforto do índice 


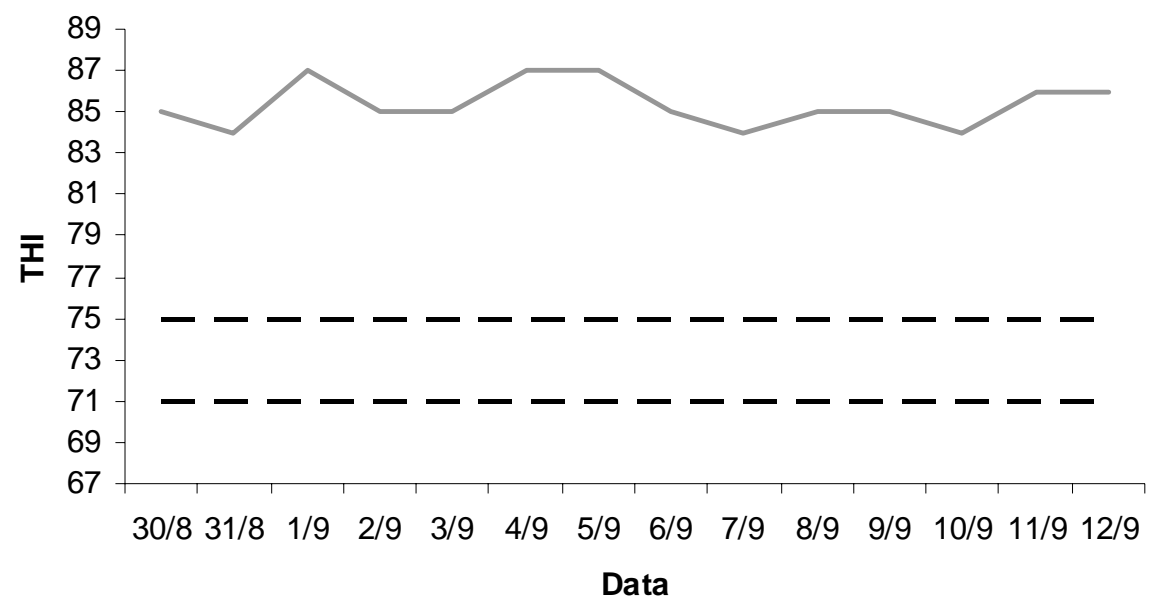

- - THIconf. sup. - THIconf. inf. $\longrightarrow$ THIreal

Figura 18 - Índice de temperatura e umidade em câmara climática na condição de estresse (THIreal) e a faixa considerada ideal para aves, com os respectivos limites, inferior e superior de conforto do índice

Analisando-se as figuras, observa-se que o indicativo de conforto em questão está condizente com os resultados encontrados para as duas condições estudadas, nota-se claramente pela Figura 17 que a condição de conforto estabelecida reflete uma tendência de valores de THI dentro da faixa estabelecida, ou seja, de 71 a 75 . Por outro lado, quando se analisa a condição de estresse (Figura 18), verifica-se que os valores do THI superam a zona de conforto térmico, caracterizando, assim, uma condição de estresse e confirmando as diferenças entre as duas condições estudadas.

\subsubsection{Entalpia}

As Figuras 19 e 20 abaixo mostram o comportamento da Entalpia (KJ / Kg ar seco) para as condições de conforto e estresse térmico, bem como a respectiva faixa com os valores limites considerados como "ideais" para aves. 


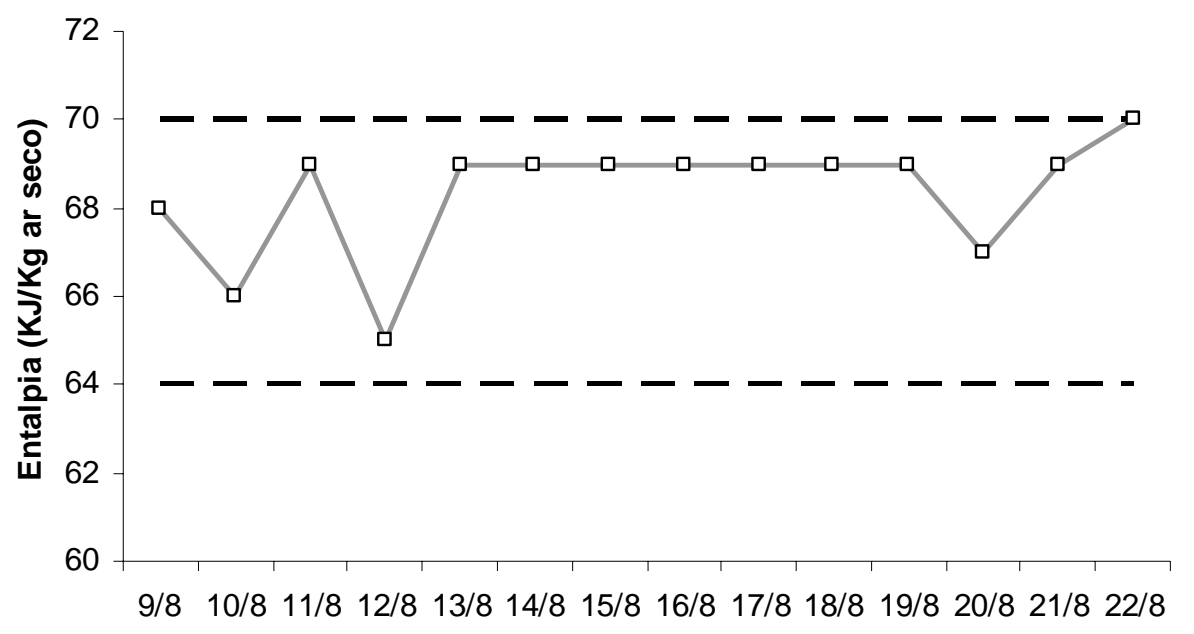

Data

— - Entalp. Conf. Inf. — - Entalp. Conf. Sup. — — Entalp. real

Figura 19 - Valores de Entalpia em câmara climática para a condição de conforto (Entalp. Real) e a faixa considerada ideal para aves, com os respectivos limites, inferior e superior de conforto

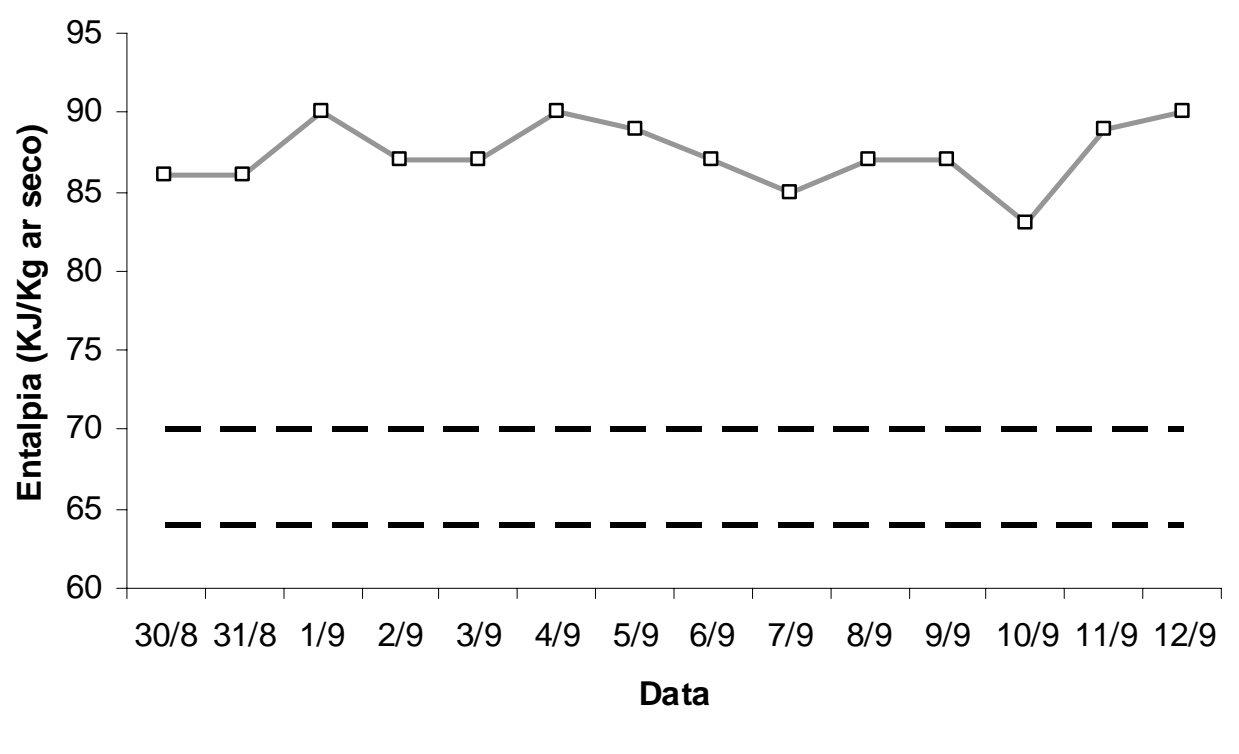

- - Entalp. conf. sup. — - Entalp. conf. inf. — $\longrightarrow$ Entalp. real

Figura 20 - Valores de Entalpia em câmara climática para a condição de estresse (Entalp. Real) e a faixa considerada ideal, com os respectivos limites, inferior e superior de conforto 
Mais uma vez é possível verificar a validade das condições ambientais propostas. A diferença entre as condições estudadas pode ser visualizada analisandose as Figuras 19 e 20, em que, pela Figura 19, nota-se que os valores médios de quantidade de energia existente na massa de ar seco estão dentro das faixas limites de conforto para o índice. Por sua vez, analisando-se a Figura 20, nota-se que este mesmo fato não é observado quando a análise é realizada para a condição de estresse, em que os valores da entalpia são superiores aos de conforto.

\subsection{Parâmetros fisiológicos}

\subsubsection{Temperatura retal e Freqüência respiratória}

A Figura 21 apresenta as médias da variável fisiológica temperatura retal (TR), para as duas condições de ambiente propostas (conforto e estresse), bem como para as linhagens estudadas (Hy-Line W36 e Hy-Line Brown) e para os sistemas de criação (cama+ninho e gaiolas).

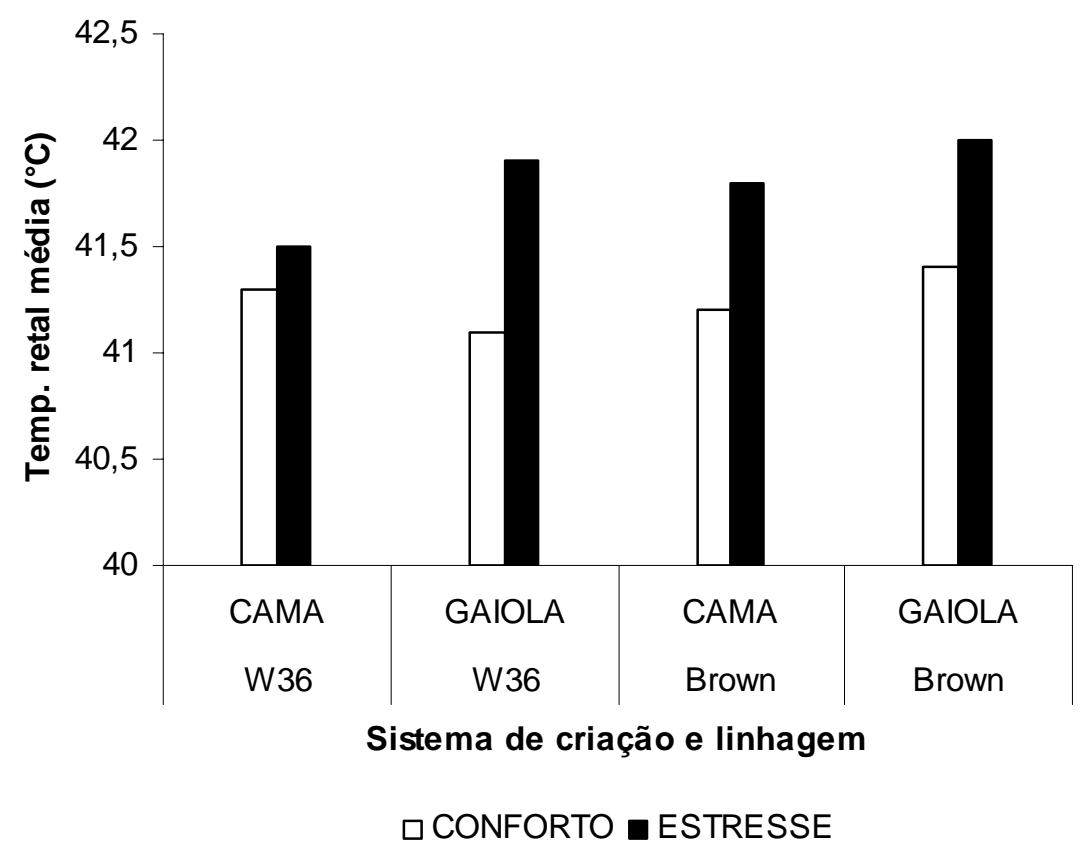

Figura 21 - Valores de Temperatura retal (TR), em função das linhagens, condições ambientais e sistema de criação 
Pela análise da Figura 21 e da Tabela 3, verifica-se um aumento significativo $(\mathrm{P}<0,05)$ na temperatura retal das aves para a condição de estresse térmico, independentemente da linhagem e do sistema de criação, o que esta de acordo com estudos realizados por Harrison \& Biellier (1968). Quanto ao sistema de criação, no sistema "cama+ninho", as aves apresentaram menores valores médios de temperatura retal (Tabela 3), quando comparado com o sistema de criação em gaiolas. Uma das causas que pode ter contribuído para esta diferença esta relacionada a maior área disponível para cada ave que o sistema em cama proporcionou, o que certamente facilitou as trocas térmicas e a circulação do ar entre os animais.

Quanto à diferença de temperatura entre as linhagens, nota-se pela Tabela 3 que a linhagem Hy-Line Brown (semipesada) apresentou valores mais elevados de temperatura retal, tanto para a condição de conforto, quanto para a condição de estresse.

A tabela abaixo mostra os valores médios de temperatura retal (TR) para as diferentes linhagens quanto ao sistema de criação e a condição ambiental a que foram submetidas.

Tabela 3. Valores médios de temperatura retal (TR), para as diferentes linhagens quanto aos sistemas de criação e condições ambientais

\begin{tabular}{lccccc}
\hline Linhagem & Sistema & TR & Condição & TR \\
\hline \multirow{2}{*}{ W36 } & Cama & 41,4 ac & Conforto & $41,2 \mathrm{a}$ \\
& Gaiola & $41,5 \mathrm{ac}$ & Estresse & $41,7 \mathrm{~b}$ \\
& Cama & $41,5 \mathrm{ac}$ & Conforto & $41,3 \mathrm{a}$ \\
& Brown & Gaiola & $41,7 \mathrm{bc}$ & Estresse & $41,8 \mathrm{~b}$ \\
\cline { 2 - 5 } \\
a,b - médias seguidas pelas mesmas letras, na mesma coluna, não diferem entre si pelo teste Tukey \\
$(\mathrm{P}<0,05)$.
\end{tabular}

A variável fisiológica freqüência respiratória ( $F R$ ) também se mostrou bem diferente, quando comparadas as duas condições ambientais a que as aves foram submetidas. Para a condição de conforto, por exemplo, as médias para as aves criadas no sistema "cama+ninho" ficaram em torno de 160 a 180 movimentos por minuto, já para a condição de criação em gaiolas ficou em torno de 180 a $200 \mathrm{mov} / \mathrm{min}$. Para a condição ambiental de estresse as medias foram de 260 a $280 \mathrm{mov} / \mathrm{min}$ em cama+ninho e 300 a $320 \mathrm{mov} / \mathrm{min}$ para condição de criação em gaiola. 
Esses resultados estão de acordo com os obtidos por Harrison \& Biellier (1968), que constataram em seu estudo que há uma relação inversa da taxa respiratória e da taxa de batimentos cardíacos, sendo que, sob altas temperaturas a tendência é um aumento da taxa respiratória e uma redução nos batimentos cardíacos, o que, por sua vez, teria uma relação direta com o balanço ácido-base das aves, que como resultado afetaria parâmetros de qualidade do ovo, tais como a espessura da casca e a gravidade específica.

Também foi possível constatar, durante o período de estresse térmico, um grande aumento no número de ofegações pelas aves. Esse é um ótimo mecanismo que as aves tem para perder calor por evaporação, mas segundo Mueler (1966), citado por Harrison \& Biellier (1968), logo quando se inicia o processo de ofegação, tem início também um processo de alcalose respiratória, que pode ser suficiente para reduzir os valores de espessura de casca em até $12 \%$.

\subsection{Consumo de água e ração}

Pode-se notar, pela Figura 22, a diferença no consumo de água entre as duas condições de ambiente (conforto e estresse) e entre os valores de temperatura da água nos reservatórios.

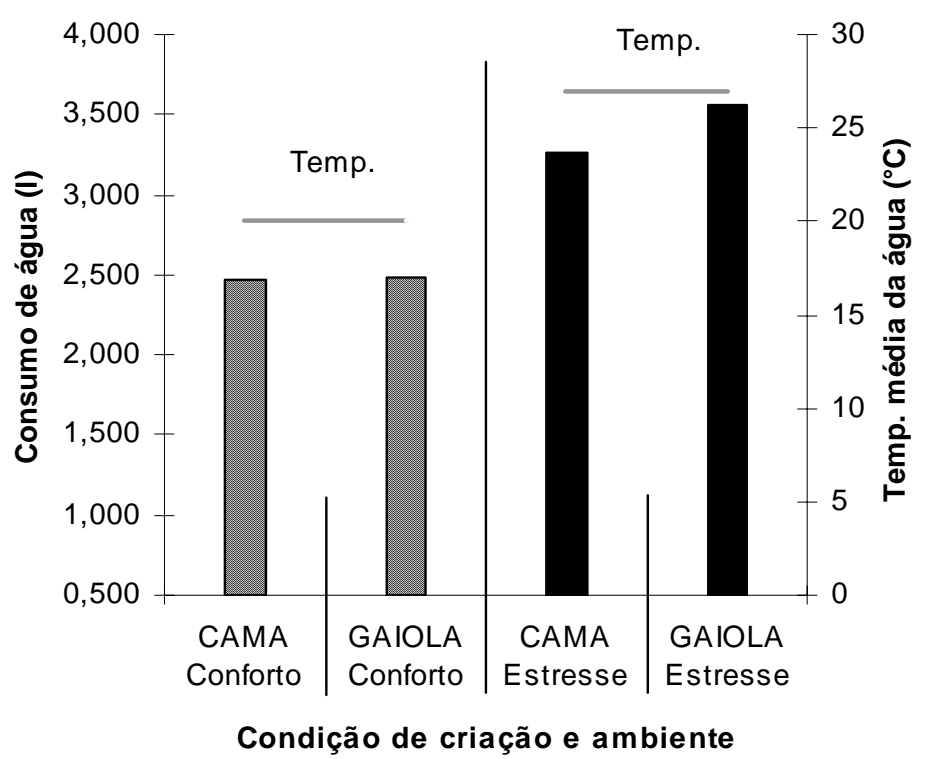

Figura 22 - Valores de consumo de água e temperatura média da água em função das condições ambientais e sistemas de criação 
Na Figura 22 acima e pela Tabela 4 abaixo, é possível verificar um aumento significativo $(\mathrm{P}<0,05)$ na quantidade de água consumida pelas aves quando submetidas às condições de ambiente de estresse térmico. Para os sistemas de criação, o aumento no consumo de água só foi significativo para a condição de estresse térmico e sistema de criação em gaiolas.

Em condições de estresse térmico, o aumento no consumo de água para o sistema de criação em gaiolas chegou a mais de $50 \%$ quando comparado ao consumo em condições de conforto, sendo que este consumo médio chegou a aproximadamente $0,4 \mathrm{l} / \mathrm{ave} / \mathrm{dia}$. Para a condição de criação em cama, o aumento no consumo de água em condições de estresse térmico, ficou em torno de $30 \%$, e o consumo médio ficou em torno de $0,3 \mathrm{l} /$ ave/dia.

Tabela 4. Valores médios de consumo e temperatura da água para as condições ambientais e sistemas de criação

\begin{tabular}{cccc}
\hline Ambiente & Sist. Criação & Água & Temp. Água \\
\hline \multirow{2}{*}{ Conforto } & Cama & $2,400 \mathrm{a}$ & $22,5 \mathrm{a}$ \\
& Gaiola & $2,500 \mathrm{a}$ & $22,6 \mathrm{a}$ \\
\multirow{2}{*}{ Estresse } & Cama & $3,100 \mathrm{~b}$ & $26,6 \mathrm{~b}$ \\
& Gaiola & $3,800 \mathrm{c}$ & $26,7 \mathrm{~b}$ \\
\hline
\end{tabular}

a,b,c, médias seguidas pelas mesmas letras, na mesma coluna, não diferem entre si pelo teste Tukey $(\mathrm{P}<0,05)$.

Esse aumento no consumo de água para as condições de estresse térmico, de acordo com Silva (1998), pode ser explicado pela maior necessidade de trocar ou perder calor para o meio em condições de altas temperaturas, uma vez que beber água é um mecanismo que auxilia na perda de calor corporal.

Outro ponto que também deve ser observado na Figura 22 é quanto à quantidade de água consumida pelas aves para as duas condições de criação dentro de uma mesma condição ambiental. O que se pode notar é que, para a condição de conforto térmico, o consumo de água das aves dentro dos dois sistemas de criação quase não apresentou diferença, uma vez que para a condição de estresse a diferença foi um aumento de aproximadamente $25 \%$ no consumo de água do sistema de criação em gaiolas em comparação ao sistema em cama. 
Essa diferença pode ser explicada talvez por uma maior facilidade das aves em perder calor no sistema de criação em cama, onde o espaço por ave é maior que no sistema em gaiolas. Outro motivo estaria relacionado ao enriquecimento do ambiente em que as aves se encontram, ou seja, o sistema de criação em gaiolas não apresenta nenhum tipo de atrativo às aves, e conforme Appleby et al. (1993), sabe-se que as aves são animais curiosos que sempre estão procurando algo para bicar. Sendo assim o bico do bebedouro tipo Nipple seria um bom atrativo para que as aves explorassem seu instinto natural de investigação, o que poderia levar, por conseqüência, a um maior consumo de água pelas aves.

Quanto aos valores de consumo de ração durante as condições de conforto e estresse, é possível observar pela Figura 23 abaixo que, conforme estudos realizados por Scott \& Belnave, (1988); Muiruri \& Harrison (1991) e Mashaly et al. (2004), ocorre uma queda significativa (Tabela 5) no consumo de ração pelas aves quando estas são expostas a condições de altas temperaturas. Conforme Hurwitz et al. (1990), a diminuição do apetite das aves pode ser considerado como um dos principais sinais de estresse térmico.

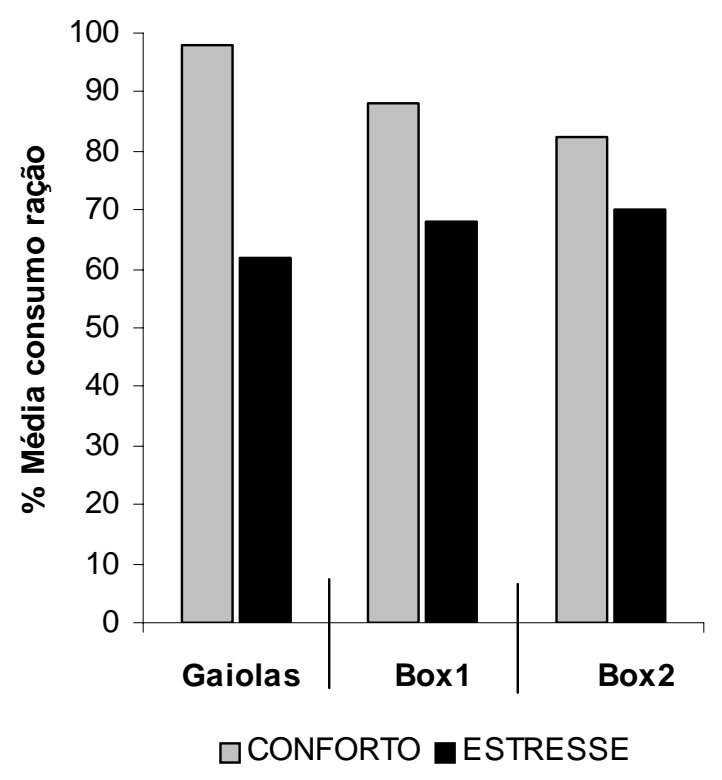

Figura 23 - Percentuais de consumo de ração em função das linhagens, condições ambientais e sistemas de criação 
Observando-se também o consumo de ração dentro do mesmo sistema de criação, pode-se notar uma diferença bem maior na queda de consumo de ração das aves criadas dentro do sistema de criação em gaiolas, isso pode ser explicado pela maior carga de estresse a que as aves criadas nestas condições de confinamento estão submetidas.

Tabela 5. Valores médios de consumo de ração ( $\mathrm{g}$ ) para as diferentes condições ambientais e sistemas de criação

\begin{tabular}{ccc}
\hline Ambiente & Sist. Criação & Ração \\
\hline \multirow{2}{*}{ Conforto } & Gaiola & $998,8 \mathrm{a}$ \\
& Cama & $946,3 \mathrm{~b}$ \\
\multirow{2}{*}{ Estresse } & Gaiola & $629,6 \mathrm{a}$ \\
& Cama & $778,7 \mathrm{~b}$ \\
\hline
\end{tabular}

a,b - médias seguidas pelas mesmas letras não diferem entre si pelo teste Tukey $(P<0,05)$.

\subsection{Parâmetros comportamentais}

De acordo com Johnson \& Hogg (1996), monitorar aves tem algumas dificuldades particulares, uma vez que estas tem comportamentos as vezes imprevisíveis e que podem acontecer de maneira muito rápida, o que pode dificultar as análises.

Segundo Sergeant et al. (1998), mesmo com a facilidade das análises em vídeo, estas deverão ser feitas por somente uma pessoa, pois as chances de duas ou mais pessoas produzirem observações de comportamento idênticas são muito raras.

\subsubsection{Expressão dos comportamentos para a condição de conforto e sistema de criação "cama+ninho"}

$\mathrm{Na}$ avaliação dos comportamentos para a condição de conforto e sistema de criação "cama+ninho", é evidente, como se pode observar pela Tabela 6, a expressão dos chamados "comportamentos de conforto" por parte das aves.

Um fator que exerce muita influência na expressão dos comportamentos das aves é o horário, uma vez que todos os animais seguem um biorritmo. A este borritmo esta ligado principalmente o aspecto fotoperíodo, que neste trabalho foi de $16 \mathrm{~L}: 8 \mathrm{E}$, ou 
seja, 16 horas de luz por 8 horas de escuro, sendo o período de luz compreendido entre o horário das 8:00 às 24:00h.

\begin{tabular}{|c|ccccccc|}
\hline \multicolumn{7}{|c|}{ Condição de conforto } \\
\hline \multirow{2}{*}{$\begin{array}{c}\text { Padrão de } \\
\text { comportamentos }\end{array}$} & \multicolumn{2}{|c|}{ Período da manhã } & Período da tarde & \multicolumn{2}{c|}{ Total } \\
\cline { 2 - 8 } & Hy-Line & Hy-Line & Hy-Line & Hy-Line & Hy-Line & Hy-Line \\
& Brown & W36 & Brown & W36 & Brown & W36 \\
\hline Comendo & 32 & 28 & 23 & 20 & 27,5 & 24 \\
\hline Bebendo & 4 & 2 & 4 & 1 & 4 & 1,5 \\
\hline Ciscando & 29 & 11 & 23 & 14 & 26 & 12,5 \\
\hline Proc. Ninho & 21 & 13 & 12 & 0,4 & 16,5 & 6,7 \\
\hline Postura & - & 26 & - & 18 & - & 22 \\
\hline Mov. conforto & 1 & 1 & 1 & 1 & 1 & 1 \\
\hline Invest. penas & 6 & 4 & 7 & 7 & 6,5 & 5,5 \\
\hline Empoleirar & - & 15 & 9 & 19 & 4,5 & 17 \\
\hline Banho de areia & 7 & - & 9 & 4 & 8 & 2 \\
\hline Agressividade & - & - & - & 1 & - & 0,5 \\
\hline Sentada & - & - & 8 & 12 & 4 & 6 \\
\hline Parada & - & - & 4 & 3 & 2 & 1,5 \\
\hline Total & 100 & 100 & 100 & 100,4 & 100 & 100,2 \\
\hline
\end{tabular}

Quadro 1 - Valores percentuais de tempo médio, em que as aves expressaram seus comportamentos na condição de conforto térmico

Pelo Quadro 6, verifica-se que, na comparação entre linhagens, a Hy-Line Brown, para o período da manhã, permaneceu uma maior parte do tempo comendo, bebendo, ciscando, procurando ninho, tomando banho de areia e investigando penas, quando comparada com a linhagem Hy-Line W36. Em contrapartida a linhagem HyLine W36 apresentou uma maior porcentagem de tempo empoleirada e em postura. Para o período da tarde, a diferença ocorreu devido à expressão de comportamentos como sentar, ficar parada e a ocorrência de agressividade, sendo este último comportamento apresentado somente pela linhagem Hy-Line W36. 
Outro ponto interessante é a verificação do comportamento de postura na parte da tarde, que, como ocorrido na parte da manhã, só foi constatado pela linhagem HyLine W36. Provavelmente este comportamento esteja relacionado com a melhor adaptação desta linhagem à postura, o que pode ser comparado pela porcentagem de tempo de expressão deste comportamento com relação a outra linhagem avaliada.

Outro fator que também deve ser considerado na avaliação dos comportamentos é a influência do período de avaliação (manhã e tarde) na expressão dos comportamentos, ou seja, no período da manhã as aves passaram mais tempo comendo (aproximadamente 30\%), certamente devido ao horário de araçoamento. Outros comportamentos que também merecem destaque no período da manhã, são os comportamentos de ciscar e o de procurar o ninho, além do comportamento de empoleirar que aparece com uma porcentagem de tempo (15\%) considerável para a linhagem Hy-Line W36.

Para o período da tarde, nota-se uma ligeira queda no comportamento de comer e um aumento nos comportamentos de investigar penas, empoleirar, tomar banho de areia e ficar parada. Além destes comportamentos, aparece também o de agressividade.

Em uma análise geral do Quadro 1, nota-se que, para a condição de conforto e sistema de criação em cama, as linhagens não apresentaram muitas diferenças quanto às expressões dos comportamentos avaliados, tanto para o período da tarde quanto para o período da manhã.

\subsubsection{Expressão dos comportamentos para a condição de estresse e sistema de criação "cama+ninho"}

O que se pode notar com relação à expressão dos comportamentos das aves na condição de estresse térmico é que, em comparação com a condição de conforto, as aves não apresentam, ou apresentam pouco, a expressão dos chamados "movimentos de conforto". Outra característica da situação de estresse apresentada pelas aves é o aumento no comportamento de beber água, Sturkie (1967) e a queda brusca no comportamento de se alimentar, Payne (1967). Um fato que também chama a atenção é o grande aumento na expressão dos comportamentos de sentar e de ficar parada, certamente são medidas comportamentais que influenciam diretamente na 
fisiologia dos animais, de modo a não aumentar a produção de calor através de movimentos.

No quadro abaixo pode-se observar o comportamento das aves, sendo que as observações foram realizadas no intervalo de 1 hora no período da manhã (das 10:00 às 11:00 h) e 2 horas para o período da tarde (das 13:00 às 14:00 h e das 16:00 às 17:00 h).

\begin{tabular}{|c|ccccccc|}
\hline \multicolumn{7}{|c|}{ Condição de estresse } \\
\hline \multirow{2}{*}{$\begin{array}{c}\text { Padrão de } \\
\text { comportamentos }\end{array}$} & \multicolumn{2}{c}{ Período da manhã } & Período da tarde & \multicolumn{2}{c|}{ Total } \\
\cline { 2 - 8 } & Hy-Line & Hy-Line & Hy-Line & Hy-Line & Hy-Line & Hy-Line \\
\hline Comendo & 20 & W36 & Brown & W36 & Brown & W36 \\
\hline Bebendo & 8 & 9 & 16 & 25 & 18 & 30,5 \\
\hline Ciscando & 19 & 25 & 26 & 19 & 22,5 & 22 \\
\hline Proc. Ninho & - & - & - & 25 & - & 12,5 \\
\hline Postura & - & - & - & - & - & - \\
\hline Mov. conforto & - & - & - & - & - & - \\
\hline Invest. penas & 3 & 4 & 5 & 5 & 4 & 4,5 \\
\hline Empoleirar & 24 & - & 19 & 4 & 21,5 & 2 \\
\hline Banho de areia & - & - & - & - & - & - \\
\hline Agressividade & - & - & - & - & - & - \\
\hline Sentada & 2 & 14 & 4 & 6 & 3 & 10 \\
\hline Parada & 24 & 12 & 24 & 10 & 24 & 11 \\
\hline Total & 100 & 100 & 100 & 100 & 100 & 100 \\
\hline
\end{tabular}

Quadro 2. Valores percentuais de tempo médio, em que as aves expressaram seus comportamentos na condição de estresse térmico

Analisando-se o Quadro 2 com relação às linhagens estudadas, pode-se observar que a linhagem Hy-Line W36 passou mais tempo comendo do que a linhagem Hy-Line Brown, tanto para o período da manhã quanto para o período da 
tarde, o que indica que a linhagem Hy-Line W36, mesmo em condições de estresse térmico, tem um melhor desempenho, uma vez que consome mais ração.

Outro ponto importante a ser observado é quanto à porcentagem do tempo que as aves da linhagem Hy-Line Brown passaram paradas (24\%) com relação às da linhagem Hy-Line W36, o que evidencia que esta linhagem certamente seja menos resistente às condições de estresse térmico.

Quanto ao comportamento de empoleirar, nota-se que no período da tarde a linhagem Hy-Line Brown reduz sua porcentagem de tempo empoleirada e que, por sua vez, a linhagem Hy-Line W36 passa a expressar este comportamento.

Com relação aos comportamentos ditos de conforto, tais como banho de areia e movimentos de conforto, estes não ocorreram para a condição de estresse, tanto no período da manhã como no período da tarde, o que confirma os efeitos do estresse provocados por altas temperaturas e umidade relativa na expressão dos comportamentos normais das aves.

\subsubsection{Expressão dos comportamentos para o sistema de criação em gaiolas}

A análise dos comportamentos para o sistema convencional de criação, ou seja, para o sistema em gaiolas, foi mais difícil de ser realizada, uma vez que problemas como o posicionamento das câmeras de vídeo (instaladas no teto), e a quantidade de aves por gaiola (5 aves/gaiola), impediram uma análise mais apurada das imagens, como a que foi realizada para a condição de "cama+ninho".

Outro problema foi o da impossibilidade de uma completa avaliação individual das aves, uma vez que, devido à distância das câmeras de vídeo e da aglomeração dos animais na gaiola o tipo de marcação utilizado não se mostrou muito eficiente em distinguir os animais.

Diante disso, as análises foram realizadas de forma mais geral, ou seja, analisando-se o conjunto das aves nas gaiolas, ou o conjunto de seus comportamentos para as condições de ambiente propostas.

Sendo assim, para a condição de conforto térmico, pôde ser observado que o grupo de aves da linhagem Hy-Line Brown e da Hy-Line W36, nos períodos da manhã e tarde, passaram a maior parte do tempo comendo. Outros comportamentos que também puderam ser evidenciados foram o de investigar penas e o de beber água. 
Para a condição de estresse térmico, os comportamentos que foram detectados com maior freqüência, principalmente na parte da tarde, foram os de sentar-se, ficar parada e o de beber água, todos estes característicos de aves sob condições de estresse. O comportamento de comer ração também apresentou uma grande redução (cerca de 50\%), principalmente para a linhagem Hy-Line Brown.

Comportamentos como movimentos de conforto, postura e pré-postura não puderam ser analisados, uma vez que, não se tinha certeza dos momentos de início e fim das expressões destes.

\subsubsection{Expressão dos comportamentos x Condição ambiental}

Para uma melhor visualização e discussão dos percentuais de expressão dos comportamentos de cada linhagem avaliada e de cada condição ambiental a que foram submetidas, tem-se o Quadro 3 abaixo, onde são apresentados os valores totais de porcentagem de tempo de expressão de cada comportamento, para as condições de conforto e estresse.

Com base no Quadro 3 abaixo cabe a discussão dos seguintes comportamentos avaliados:

Comer - Comportamento característico dos períodos da manhã, tanto para a condição de conforto quanto para a de estresse, em função do horário que as aves recebiam ração.

Como se pode observar no Quadro 3, houve uma redução na porcentagem de tempo em que a linhagem Hy-Line Brown passou comendo ração. Estes dados estão de acordo com os descritos por autores como Warren \& Schnepel (1940); de Andrade (1976); Scott \& Belnave (1988) e Mashaly et al. (2004), que constataram uma redução significativa no consumo de ração durante períodos de altas temperaturas. Por outro lado, para a linhagem Hy-Line W36 ocorreu o contrario, ou seja, mesmo sob condições de estresse térmico, a linhagem se mostrou mais resistente, o que pode ser comprovado pelo aumento verificado na porcentagem de tempo que as aves desta linhagem passaram comendo, o que por sua vez, indicaria um melhor desempenho desta linhagem com relação às condições ambientais. 


\begin{tabular}{|c|cccc|}
\hline \multirow{2}{*}{$\begin{array}{c}\text { Padrão de } \\
\text { comportamentos }\end{array}$} & \multicolumn{2}{|c}{ Conforto } & \multicolumn{2}{c|}{ Estresse } \\
\cline { 2 - 5 } & By-Line & Hy-Line & Hy-Line & Hy-Line \\
Brown & W36 & Brown & W36 \\
\hline Comendo & 27,5 & 24 & 18 & 30,5 \\
\hline Bebendo & 4 & 1,5 & 7 & 7,5 \\
\hline Ciscando & 26 & 12,5 & 22,5 & 22 \\
\hline Proc. Ninho & 16,5 & 6,7 & - & 12,5 \\
\hline Postura & - & 22 & - & - \\
\hline Mov. conforto & 1 & 1 & - & - \\
\hline Invest. penas & 6,5 & 5,5 & 4 & 4,5 \\
\hline Empoleirar & 4,5 & 17 & 21,5 & 2 \\
\hline Banho de areia & 8 & 2 & - & - \\
\hline Agressividade & - & 0,5 & - & - \\
\hline Sentada & 4 & 6 & 3 & 10 \\
\hline Parada & 2 & 1,5 & 24 & 11 \\
\hline Total & 100 & 100,2 & 100 & 100 \\
\hline
\end{tabular}

Quadro 3 - Valores percentuais médios totais de tempo, em que as aves expressaram seus comportamentos para as condições de conforto e estresse térmico

Quanto aos sistemas de criação, no sistema em gaiolas foi possível notar um aumento no consumo de ração, o que é uma característica dos animais, quando submetidos às condições de confinamento, Huges \& Duncan (1988), já que não tem outra alternativa para passar o tempo. Entende-se que no sistema de criação em cama, por apresentar um ambiente mais rico e oferecer outras opções as aves, que não somente comer, possa ter contribuído para esta diferença, uma vez que se observou uma distribuição maior nas porcentagens de tempo gastos em outras atividades.

Quanto ao aspecto bem-estar das aves, o sistema de criação em gaiolas apresentou maiores dificuldades às aves em acessar o comedouro, principalmente devido à área de gaiola disponível por ave $\left(<\right.$ de $\left.500 \mathrm{~cm}^{2}\right)$. Provavelmente a frustração 
deste comportamento possa ter contribuído para aumentar a agressividade das aves em disputas por espaço para se alimentar.

É importante atentar também para o fato de que as recomendações da norma da União Européia são de que os comedores lineares, como os utilizados nesta pesquisa, devem fornecer um espaço de pelo menos $10 \mathrm{~cm}$ por ave. COMISSÃO EUROPÉIA, Directiva 1999/74/EC (1999). Sendo que o comedouro utilizado nesta pesquisa estava dentro desta exigência.

Beber - Somente pela análise deste comportamento é possível dizer sob qual condição ambiental estavam submetidas as aves. Isso porque, ao se analisar as porcentagens médias de tempo de expressão de cada comportamento (Quadro 3), fica nítida a diferença de consumo de água para as diferentes condições ambientais.

Para a condição de estresse térmico, o comportamento de beber água chega a aumentar quase o dobro, no caso da linhagem Hy-Line Brown, quando comparado com a condição de conforto. Isso ocorre principalmente por que os animais tendem a aumentar o consumo de água na intenção de aumentar a perda de calor corporal, ou seja, é uma defesa do animal contra as altas temperaturas.

A linhagem Hy-Line W36 teve um aumento de 5 vezes no valor de consumo de água para a condição de estresse, que pode ter ocorrido em função do maior consumo de ração para esta condição ambiental.

Provavelmente outro ponto que pode ter afetado a taxa de expressão deste comportamento foi a temperatura da água, que teve um aumento de aproximadamente $7^{\circ} \mathrm{C}$ quando a condição passou da de conforto para a de estresse.

Para a condição de sistema de criação em gaiola, o comportamento de beber água não teve muita diferença do apresentado no sistema "cama+ninho", sendo este também muito maior para a condição de estresse térmico.

A diferença na quantidade de água consumida no sistema de criação em gaiolas pode também, em parte, ser explicado, como já mencionado (Tabela 4), pela falta de enriquecimento do ambiente onde se encontravam as aves, ou seja, a gaiola é um ambiente que oferece poucos atrativos às aves, e um dos poucos, senão até mesmo o único neste sistema é o bico do bebedouro tipo Nipple, que muitas vezes é utilizado não para matar a sede das aves, mas como uma forma de "distração" em meio a uma condição muito propícia a ocorrência de estresse. 
Sob o ponto de vista do bem-estar das aves, o aumento ou diminuição deste comportamento pode estar relacionado com as condições de estresse a que o animal possa estar sendo submetido, decorrente principalmente do confinamento e da impossibilidade de execução natural dos comportamentos.

Investigar penas - Comportamento não agressivo, caracterizado quando a ave investiga suas próprias penas com o bico ou investiga as penas de outras aves.

Pode ser considerado um comportamento de conforto, uma vez que é nítida a diferença na porcentagem de tempo de expressão deste comportamento para as condições ambientais propostas.

Isso pode ser explicado, pois, quando a ave se encontra em ambientes de altas temperaturas, sua tendência é diminuir as atividades físicas e separar as asas do corpo na intenção de aumentar as trocas de calor com o meio. Isso faz com que as aves diminuam a freqüência com que investigam suas penas, uma vez que este comportamento requer movimentos de cabeça e asas simultâneos, o que aumentaria as atividades físicas e, conseqüentemente, a produção de calor.

Analisando o Quadro 3, é possível notar uma diminuição das porcentagens de expressão deste comportamento para a condição de estresse, principalmente para a linhagem Hy-Line Brown.

Em contrapartida, é um comportamento natural das aves, sendo que aparece em todas as condições ambientais e em todas os sistemas de criação, variando somente em intensidade de execução.

Com relação ao bem-estar das aves, este é um comportamento considerado muito importante, pois é através dele que as aves arrumam ou organizam suas penas e espalham o óleo proveniente da glândula uropigiana.

Banho de areia - Comportamento característico e natural das aves, envolve em sua caracterização uma seqüência de ciscar e jogar o material utilizado como cama sobre o corpo, além de movimentos rápidos de chacoalhar as penas.

Comprovando o que foi verificado por Appleby et al. (1993) em seu trabalho, este é um comportamento que as aves apresentam ou tendem a apresentar sob qualquer condição de criação, sendo observado até mesmo no sistema em gaiolas, onde não há espaço nem tampouco material de cama. Isso do ponto de vista do bem- 
estar animal, pode levar os animais a uma condição de frustração, causando estresse e gerando comportamentos fora dos padrões.

Conforme estudos de Hogan \& Van Boxel (1993), estímulos como iluminação e temperatura do ambiente podem determinar a hora do dia em que o banho de areia poderá ocorrer. Como se pode comprovar pelos dados apresentados, a maior parte das expressões deste comportamento ocorreu na parte da tarde, o que pode indicar que o fotoperíodo utilizado (16L:8E) e a temperatura da câmara para este horário, propiciaram a ocorrência deste comportamento.

Com relação ao Quadro 3, pode-se notar que não houve ocorrência deste comportamento para a condição ambiental de estresse, para ambas as linhagens, o que confirma que este é um comportamento de conforto.

Com relação aos dois sistemas de criação, o sistema em cama favorece e muito a expressão e maior período de duração deste comportamento, uma vez que as aves possuem uma área com cama, o que atrai os animais e aumenta o período de expressão deste comportamento. Segundo Petherick et al. (1995), a cama exerce um estimulo visual muito importante às aves e é um dos principais fatores que desencadeiam os processos do comportamento de banho de areia.

Ainda com relação a estímulos visuais, pôde-se observar que as aves pareciam em determinados momentos, seguir o mesmo tipo de comportamento e começarem a expressar o comportamento de banho de areia ao mesmo tempo ou pouco tempo após uma outra ave, isso está de acordo com Duncan et al. (1998), que puderam constatar que o estimulo visual de aves tomando banho de areia desencadeava o processo em outras, sendo ainda um dos principais responsáveis pela duração deste comportamento.

Segundo Vestergaard (1982), o tempo de duração do comportamento de banho de areia dura, em média 27 min. Este valor não foi comprovado neste estudo, uma vez que o comportamento de banho de areia, em condições de conforto e sistema de produção em cama, ficou em média em torno de 8 min e não foi verificado durante o período de estresse térmico, o que indica que, provavelmente, mais uma vez, o comportamento é deixado de lado como uma medida de não aumentar a produção de calor por meio de atividades físicas. 
Movimentos de conforto - Quando as aves se encontram em condição de conforto e bem-estar, são considerados movimentos de conforto comportamentos como: bater e esticas as asas e chacoalhar as penas.

São comportamentos que também servem para diferenciar sob qual condição ambiental estão submetidas as aves, uma vez que não ocorreu nenhuma manifestação destes comportamentos quando as aves se encontravam em condições de estresse térmico.

Para a condição de criação em sistema de gaiolas, a expressão destes movimentos se torna ainda mais crítica, uma vez que as aves se encontram confinadas em altas densidades, o que as impede de esticar as asas ou ainda chacoalhar as penas. Segundo Dawkins \& Hardie (1989) citados por Rudkin \& Stewart (2003), é necessário que haja uma área de no mínimo $860 \mathrm{~cm}^{2}$ para que comportamentos como de bater as asas possa ocorrer naturalmente.

Do ponto de vista do bem-estar animal, a expressão destes movimentos serve como um diagnóstico para se avaliar as instalações onde estão sendo criadas as aves, uma vez que, quando inibidos, as aves provavelmente estarão sob condições de estresse, e o local onde estão sendo criadas não apresenta as condições adequadas de criação sob os aspectos do bem-estar.

Quanto à questão de espaço nas gaiolas, o artigo 5ํ do Capitulo III, da Directiva 1999/74/CE da União Européia institui que "As galinhas poedeiras devem dispor de, pelo menos, $550 \mathrm{~cm}^{2}$ de superfície de gaiola por ave, medidos horizontalmente e utilizáveis sem restrições, designadamente sem levar em conta defletores antidesperdício, susceptíveis a diminuir a superfície disponível" e que "As gaiolas devem ter uma altura mínima de $40 \mathrm{~cm}$ em $65 \%$ da extensão da gaiola e de $35 \mathrm{~cm}$ em quaisquer outros pontos", COMISSÃO EUROPÉIA, (1999).

Sendo assim, como a gaiola utilizada nesta pesquisa não cumpre todos estes requisitos (vide Tabela 1), comportamentos que requerem espaço para serem demonstrados, como os em questão, acabam ficando muito prejudicados, uma vez que embora a ave até tente executá-los, não conseguirá devido às dimensões da gaiola, o que na maioria das vezes leva os animais à frustração e conseqüentemente ao estresse. 
Ciscar - Comportamento considerado característico e natural das aves, caracterizado quando a ave explora seu território com seus pés e bico. É um dos comportamentos mais fáceis de se verificar pela análise de imagens, por ser muito característico e com movimentos claros das aves.

Analisando-se os dados das porcentagens médias de expressão dos comportamentos para cada condição ambiental proposta, pode-se notar que a mesma tendência de se movimentar o mínimo possível em condições de estresse térmico apresentada pelas aves em outros tipos de comportamento também é uma característica na expressão deste, ou seja, as aves ciscam menos em condições de altas temperaturas.

Quanto ao comportamento de ciscar, para a linhagem Hy-Line Brown não ocorreram grades modificações nas porcentagens de expressão deste comportamento para as duas condições ambientais estudadas, já para a linhagem Hy-Line W36 houve um aumento de quase $80 \%$ no tempo de expressão deste comportamento para a condição de estresse térmico, o que indica mais uma vez um melhor desempenho desta linhagem perante as condições ambientais avaliadas.

Para a condição de criação em gaiolas, as aves tendem, mesmo sem a presença de nenhum substrato, a apresentar o comportamento de ciscar o fundo das gaiolas. Isso ocorre, pois ciscar é um comportamento natural das aves, e a frustração deste comportamento provavelmente levará as aves a uma condição de estresse.

Empoleirar - Comportamento associado ao bem-estar das aves, por ser um comportamento natural.

Analisando-se os valores das porcentagens médias de tempo de expressão dos comportamentos (Quadro 3), este tipo de comportamento se mostrou independente da condição ambiental a que estavam submetidas as aves, bem como da hora do dia, sendo que a linhagem Hy-Line W36 passou mais tempo empoleirada na condição de conforto e a linhagem Hy-Line Brown, por sua vez, passou mais tempo empoleirada na condição de estresse.

Provavelmente esta inversão nos tempos de empoleiramento, se deva, conforme já comentado para os comportamentos anteriores, a uma melhor adaptação da linhagem Hy-Line W36 às condições ambientais, uma vez que, enquanto as aves da linhagem Hy-Line Brown estavam empoleiradas, as da linhagem Hy-Line W36 estavam 
executando outros comportamentos, tais como comer ou procurando ninho, que, do ponto de vista produtivo, são comportamentos muito mais interessantes.

O poleiro no sistema de criação em cama ficava a uma altura de $35 \mathrm{~cm}$ do chão e, como foi adaptado a partir do sistema de encanamento da linha de bebedouros tipo Nipple, se encontrava sempre cheio de água (poleiro refrigerado), o que, por sua vez, pode ter contribuído para um maior uso deste pelas aves, uma vez que, conforme Pereira (1991), quando a ave se encontra sobre este tipo de poleiro, ocorre uma transferência de calor dos pés da ave para o encanamento, que se encontra a uma temperatura menor, favorecendo assim a troca de calor por condução.

O fato de o poleiro favorecer as trocas de calor também pode ter influenciado no maior período de tempo em que as aves da linhagem Hy-Line Brown passaram empoleiradas na condição de estresse, uma vez que, de maneira geral verifica-se uma menor tolerância desta linhagem às condições de estresse térmico.

Durante as análises de imagens para este comportamento, foi possível se verificar também que outros comportamentos foram executados simultaneamente ao de empoleirar, ou seja, comportamentos como investigar penas e movimentos de conforto, como bater e esticar as asas, puderam ser constatados simultaneamente ao de empoleirar durante a condição térmica de conforto. Já para a condição de estresse térmico o comportamento que mais se verificou ocorrer juntamente ao de empoleirar foi o de beber água, o que também foi verificado por Rudkin \& Stewart (2003), que por sua vez classificou este comportamento como estereotipo de uma determinada ave e um determinado bico do bebedouro nipple.

Ainda segundo Rudkin \& Stewart (2003), os benefícios do poleiro ainda não são muito claros, sendo que os benefícios deste estariam mais ligados a fortalecer os ossos das pernas das aves por meio de exercícios físicos, no entanto ao auxiliar no fortalecimento dos ossos, estaria contribuindo para melhorar as condições de bemestar das aves uma vez que, diminuiria a incidência de fraturas com o avanço da idade.

Quanto aos requisitos da norma de bem-estar da Comunidade Européia para poleiros em sistema de cama, tais como: pelo menos $15 \mathrm{~cm}$ de poleiro por ave ou ainda que o poleiro deverá estar a pelo menos $20 \mathrm{~cm}$ de distância da parede, todas as exigências foram seguidas durante a pesquisa, o que provavelmente possa ter resultado em melhor aproveitamento deste item de enriquecimento do sistema. 
Agressividade - Comportamento relacionado à condição de se estabelecer dominância ou um nível de hierarquia em um grupo de aves ou ainda às condições de estresse provocadas pelo sistema de criação.

É um comportamento geralmente caracterizado por bicadas rápidas e fortes em locais como a crista e outras partes da cabeça. Foi possível constatar-se, durante o período de adaptação das aves as condições ambientais da câmara climática, que para as aves colocadas no sistema de criação em cama o estabelecimento da dominância e hierarquia aconteceu de forma rápida e com pouca expressão do comportamento de agressividade, sendo que depois de estabelecida a dominância dentro do grupo, quase não se verificou mais a ocorrência deste comportamento entre as aves.

Atenção especial deve ser chamada para o fato que as aves em nenhum momento receberam algum tipo de marcação em suas cabeças ou cristas, pois isso, de acordo com Rudkin \& Stewart (2003), pode causar problemas sérios de agressividade nas aves, uma vez que a crista é utilizada pelas aves como meio de reconhecimento e identificação.

Quanto ao sistema de marcação utilizado (pintura do dorso), não foram constatados problemas de agressividade devido a este tipo de marcação.

Para a condição de criação em gaiola aconteceu que, mesmo depois de estabelecida uma dominância e uma hierarquia dentro do grupo, as aves ainda continuavam apresentando o comportamento de agressividade, provavelmente como um indicativo da maior carga de estresse sofrido pelas aves para condição de criação em confinamento.

Sentada - Comportamento caracterizado quando a ave senta na cama ou substrato que se encontra. Para o comportamento de sentar não foi considerado o período que a ave senta para botar, sendo este comportamento classificado como "comportamento de postura".

Para a caracterização do comportamento de sentar, foi levado em consideração e contabilizado o tempo em que as aves passavam sentadas fora do ninho ou fora do comportamento considerado como de postura. Este comportamento pôde ser visualizado com facilidade quando as aves se encontravam em condições de estresse térmico, uma das explicações seria quanto a necessidade de não se movimentar muito 
sob ambientes com altos valores de temperatura para facilitar as trocas térmicas com o meio.

O que esta de acordo como o verificado por Rutz (1994), que observou que quando a condição ambiental estava acima da zona termoneutra das aves, suas atividades físicas eram reduzidas, a fim de diminuir a produção interna de calor, sendo assim passavam mais tempo sentadas.

Outra explicação seria que sentadas e em contato com a cama as aves estariam mais próximas do chão (cerâmico) da câmara, que certamente estaria mais frio que o ambiente e favoreceria as trocas de calor por condução das aves.

Observando-se o Quadro 3, com relação as linhagens avaliadas, pode-se notar que a linhagem Hy-Line W36 passa uma maior porcentagem de tempo sentada, tanto para a condição de conforto, quanto para a condição de estresse.

Para o sistema de criação em gaiolas, este comportamento não se mostrou muito diferente para as condições ambientais de conforto e estresse, sendo que a maior freqüência de aves sentadas ocorreu nos períodos da tarde.

Segundo Appleby et al. (1992) e Keeling (1994), aves criadas em sistemas com a presença de cama ou em semiconfinamento, tem uma tendência de ficarem menos tempo sentadas ou paradas, devido a uma maior disponibilidade de recursos que encontram nestes tipos de sistemas e que favorecem suas condições de bem-estar.

Procurar o ninho - Comportamento facilmente detectável e caracterizado como entradas rápidas e freqüentes das aves no ninho, como numa tentativa de avaliar o local antes de botar os ovos. É um comportamento natural das aves, executado antes da postura, por isso é classificado como um comportamento de pré-postura.

Autores como Wood-Gush (1975); Appleby et al. (1992) e Petherick et al. (1994) relataram o que foi observado neste trabalho durante a análise deste comportamento no período de análise de imagens, ou seja, o comportamento de pré-postura ou de procurar o ninho é caracterizado por um aumento rápido nas atividades locomotoras e exploratórias das aves, que avaliam de modo relativamente rápido os locais com potenciais chances para realizarem a postura.

Analisando-se os Quadros 1 e 2 de porcentagem de tempo de expressão dos comportamentos, nota-se que a maior ocorrência deste comportamento acontece no período da manhã (das 10:00 às 11:00h), isso porque o horário de postura das aves 
variava de uma a duas horas após este horário (por volta das 12:00 ou 13:00h). Isso faz sentido, pois as aves tendem a avaliar ou a procurar um local para botar os ovos, uma a duas horas antes da postura. Rudkin \& Stewart (2003).

Pelo Quadro 3, pode-se observar que para a condição de conforto térmico, ambas as linhagens apresentaram o comportamento de procurar o ninho, com destaque para a linhagem Hy-Line Brown. Já para a condição de estresse térmico, a linhagem Hy-Line W36 apresentou um melhor desempenho quanto a este comportamento. A explicação seria de que mais uma vez esta linhagem se apresenta melhor adaptada às condições de altas temperaturas e umidade.

No sistema convencional de criação em gaiolas, o comportamento de prépostura é bem diferente do apresentado em condições de criação em cama, isso porque em primeiro lugar as aves não possuem ninhos e, em segundo, lugar porque não possuem espaço sequer para iniciar um comportamento exploratório como o que é executado pelas aves soltas. Neste caso, como é relatado por Duncan et al. (1978), as aves criadas em gaiolas tendem a apresentar pouco ou quase nenhum comportamento de pré-postura, e quando este chega a acontecer, é quase imperceptível, pois acontece de maneira muito rápida e pouco expressiva.

Segundo Wood-Gush (1972), a maioria das linhagens criadas em sistema de gaiolas, principalmente as linhagens leves, apresentaram severos sintomas de frustração durante os períodos de pré-postura, provavelmente pela falta de ninho.

O que pôde ser constatado durante a análise de imagens para o sistema em gaiolas foi que para algumas aves o período de pré-postura era imperceptível ou ausente, ou seja, a ave botava sem nenhuma alteração comportamental. Já para outras aves, era possível notar que um pouco antes de botarem seus ovos, elas apresentavam uma pequena alteração em seus comportamentos, tais como, começar a girar dentro da gaiola, como se procurassem algo que perderam, começar a andar de um lado para o outro da gaiola, sentar e levantar rapidamente e várias vezes seguidas.

Devido às dificuldades de se estabelecer os momentos exatos de início e fim de certos comportamentos como o de pré-postura em questão, em condições de criação em sistema de gaiolas, e de problemas operacionais como a correta posição de instalação das câmeras de vídeo no interior da câmara climática, é que uma quantificação mais apurada dos comportamentos para o sistema de gaiolas não pôde ser executada. 
Postura - Comportamento caracterizado como a presença da ave sentada no ninho e com a posterior comprovação da presença do ovo no local. Pode ser dividido em duas categorias: postura em cama e postura em ninho.

O comportamento de postura em ninho, que é o preferencial, ocorreu em praticamente $100 \%$ das aves criadas no sistema "cama+ninho", principalmente pelo fato das aves terem se adaptado bem às condições do ninho e terem "aprendido" a utilizá-lo durante o período de adaptação às condições da câmara climática, o que resultou na pouca ocorrência de ovos postos em cama durante o período de adaptação e na ocorrência de nenhum ovo posto na cama durante o período de coleta de dados.

Segundo Rudkin \& Stewart (2003), ainda não é muito clara a razão pela qual as aves botam na cama sendo que tem o ninho a sua disposição, certamente isso deve ocorrer por problemas no ninho ou talvez por este estar ocupado por outras aves no momento da postura, ou ainda pelo fato da ave não se dar conta que tem ao seu dispor um local apropriado para realizar a postura.

No Quadro 3, a ocorrência deste comportamento aconteceu para a linhagem Hy-Line W36 no período de conforto (22\%).

Uso do Ninho - Para que o sistema de câmeras de vídeo instalado no teto da câmara climática pudesse capturar as imagens dentro dos ninhos, estes foram confeccionados com teto de vidro. Essa medida permitiu que os comportamentos de postura executados no interior dos ninhos pudessem ser analisados. Outro ponto positivo do teto de vidro foi que possibilitou também observar o número de aves que utilizavam o ninho ao mesmo tempo, bem como a identificação dos ovos de cada ave para a completa comprovação da postura.

O uso do ninho, no período de adaptação das aves, foi sendo gradativamente incorporado ao seu comportamento normal, uma vez que no início as aves ainda apresentavam o comportamento de postura em cama e, logo que se adaptaram ao ninho, passaram a realizar toda a postura nos ninhos.

O fundo dos ninhos foi forrado com o mesmo material da cama (maravalha), o que possibilitou que as aves entrassem no ninho e simulassem a sua construção através do material que se encontrava dentro dele. Essa medida de se fornecer um substrato apropriado às aves também dentro do ninho, funcionou como um atrativo às aves que, ao entrarem nos ninhos, se acomodavam ciscando a cama em seu interior e 
ajeitando-a em volta de seu corpo. Esta atração por ninhos com cama também foi encontrada por autores como Duncan \& Kite (1989) e Appleby (1990), que puderam comprovar que ninhos sem cama ou sem qualquer outro substrato exerciam menos atração às aves.

Esta medida de se colocar cama dentro dos ninhos também pode ter contribuído para o maior número de ovos limpos e sem trincas ou rachaduras que foram constatados neste local, talvez devido ao efeito colchão que a cama exerce, tornando o fundo do ninho um ambiente macio e sem perigo de quebra dos ovos. Isso esta de acordo com o relatado por Smith et al. (1993), que descobriram em seu trabalho que o ninho com cama permitiu uma menor proporção de ovos trincados ou sujos.

Sob o ponto de vista do bem-estar animal, os ninhos utilizados no sistema de criação em cama, no presente trabalho, cumpriram o seu papel, uma vez que as aves se adaptaram bem e de forma relativamente rápida a estes, o que indica que o uso do ninho é muito importante no processo de realização da postura, Wall (2002).

Ainda sob o aspecto de bem-estar, é muito importante que o ninho seja atrativo às aves e que todas o utilizem para a realização de postura. Dessa maneira, é possível se afirmar com certeza que o ninho atingiu seu objetivo, pois como foi possível observar durante a análise de imagens, em alguns momentos até três aves chegaram a ocupar o mesmo ninho simultaneamente, o que indica este, como um local considerado por todas as aves como seguro e ideal para a postura.

Parada - Comportamento caracterizado quando a ave não apresenta nenhum movimento, ou aparentemente não se enquadra em nenhum dos comportamentos anteriores. É característico de aves sob influência de estresse térmico, como já mencionado anteriormente, na tentativa de minimizar a produção de calor corporal.

No sistema de criação em gaiolas pode ser resultante, além do estresse térmico, de aspectos como agressividade, por fatores como dominância ou disputa por espaço, ou ainda pelo estresse provocado pelo alto índice de confinamento das aves.

No Quadro 3 é possível notar que, para a condição de conforto, as duas linhagens não apresentaram quase nenhuma diferença na expressão deste comportamento, sendo também o período de execução relativamente baixo (por volta de $2 \%$ ). Para a condição de estresse térmico, a situação é bem diferente, uma vez que 
a percentagem de tempo gasto com este comportamento aumenta acentuadamente, principalmente para a linhagem Hy-Line Brown, que ficou praticamente um quarto do tempo total parada.

Sob condições de estresse térmico é normal que as aves diminuam seu ritmo e passem a ficar maiores períodos paradas. Isso é um mecanismo de defesa das aves, uma vez que, ficando paradas gastam menos energia.

\subsubsection{Tempo gasto na expressão de cada comportamento para a condição de conforto e sistema de criação em cama}

Para uma melhor avaliação dos tempos gastos na expressão de cada comportamento pelas aves para o sistema de criação em cama e para a condição de conforto térmico, são apresentadas as figuras abaixo.

\section{LINHAGEM BROWN}

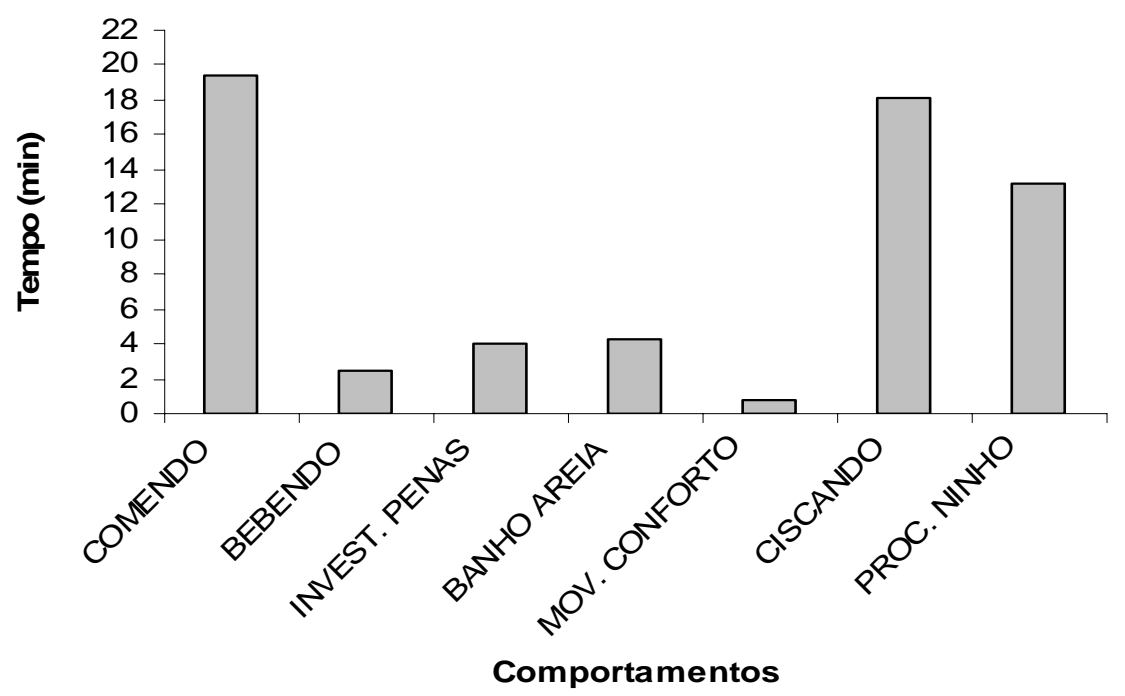

Figura 24 - Tempo médio gasto na expressão dos comportamentos da linhagem HyLine Brown no período da manhã para a condição de conforto 


\section{LINHAGEM W36}

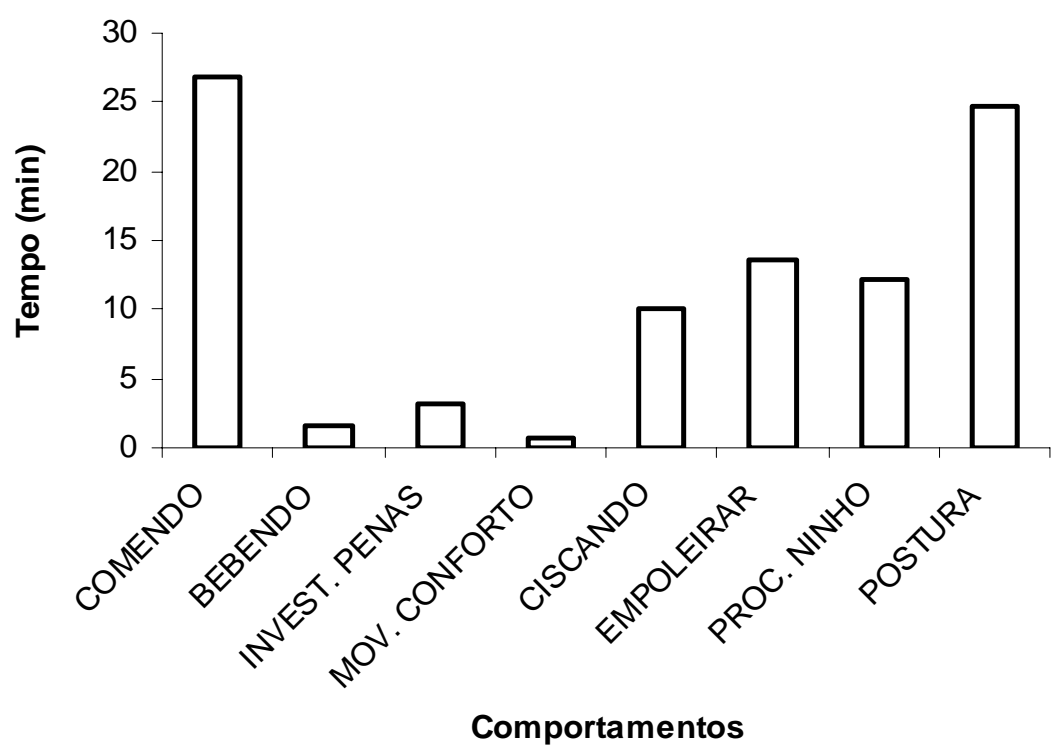

Figura 25 - Tempo médio gasto na expressão dos comportamentos da linhagem HyLine W36 no período da manhã para a condição de conforto

LINHAGEM BROWN

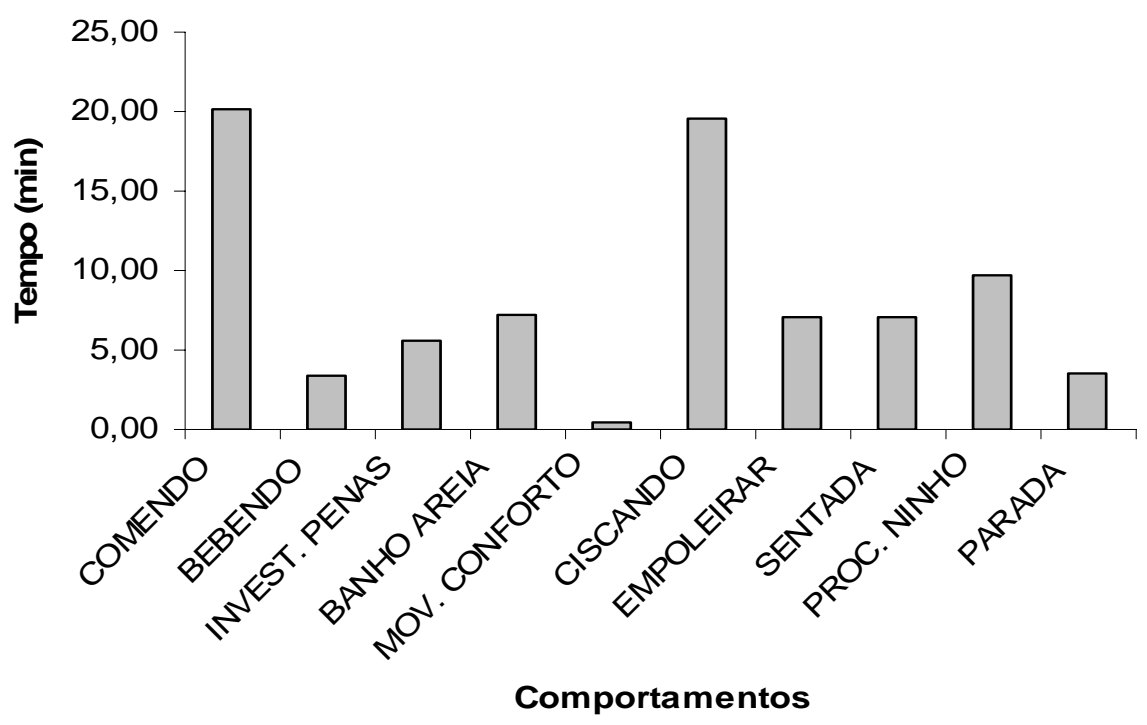

Figura 26 - Tempo médio gasto na expressão dos comportamentos da linhagem HyLine Brown no período da tarde para a condição de conforto 


\section{LINHAGEM W36}

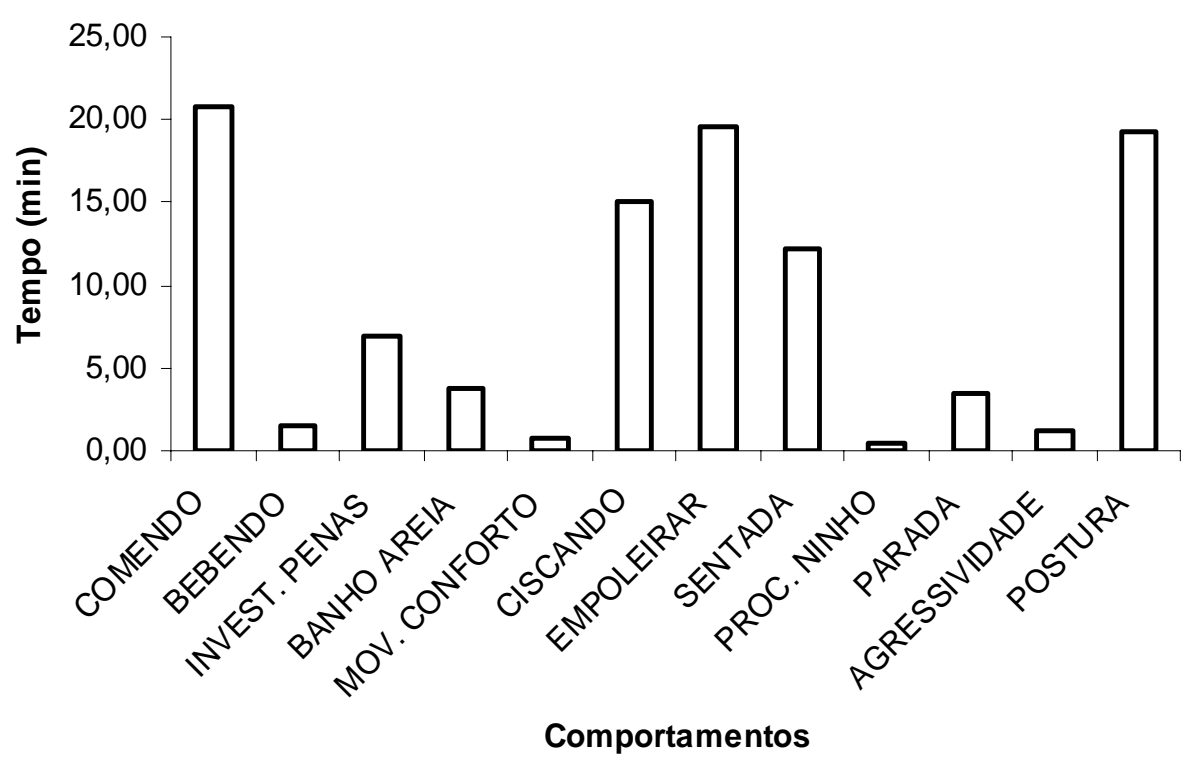

Figura 27 - Tempo médio gasto na expressão dos comportamentos da linhagem HyLine W36 no período da tarde para a condição de conforto

Analisando-se as Figuras 24 e 25 para o período da manhã (das 10:00 às 11:00 h), pode-se observar que as aves passaram em média 20 min do tempo total de avaliação (1 hora) comendo, o comportamento de beber água durou em média 2 min, e o de ciscar $16 \mathrm{~min}$. Os movimentos de conforto ficaram em torno de $2 \mathrm{~min}$, e comportamentos como empoleirar e postura só foram verificados para a linhagem HyLine W36, com tempos de respectivamente de 14 e 24 min.

O comportamento de banho de areia ocorreu somente na linhagem Hy-Line Brown, e durou um tempo de aproximadamente $4 \mathrm{~min}$. Provavelmente este tempo tenha sido curto devido ao horário em questão (período da manhã) quando as aves tendem a passar a maior parte do tempo comendo.

O comportamento de pré-postura ou de procurar o ninho pôde ser constatado para as duas linhagens e durou em média $12 \mathrm{~min}$.

Para o período da tarde (das 13:00 às 14:00 h e das 16:00 às 17:00 h), nota-se que o tempo de duração do comportamento de comer quase não foi alterado, ficando 
em média para as duas linhagens por volta de $20 \mathrm{~min}$. O comportamento de beber água mostra um aumento no tempo de duração para a linhagem Hy-Line Brown, com relação ao período da manhã, passando de 2 para 4 min, enquanto para a linhagem Hy-Line W36 este tempo não apresentou diferença.

Um comportamento que apresentou uma grande diferença, quanto ao seu tempo de duração, foi o de empoleirar, que para a linhagem Hy-Line W36 foi de aproximadamente 20 min e para a Hy-Line Brown foi de cerca de 7 min.

É possível também se notar uma queda no tempo de duração do comportamento de pré-postura para a linhagem Hy-Line W36 com relação ao período da manhã, que caiu de 12 min para $30 \mathrm{~s}$, o que indica que a postura certamente foi realizada na parte da manhã. Já a linhagem Hy-Line Brown manteve semelhante o tempo de duração deste comportamento, o que indica que nem todas as aves realizavam a postura no período da manhã. Quanto a duração do comportamento de pré-postura, Rudkin \& Stewart (2003), encontraram tempos de duração deste comportamento variando de 10 min até $2 \mathrm{~h}$.

Observando-se ainda as Figuras 26 e 27, para o período da tarde, pode-se verificar a expressão de comportamentos como o de sentar e de ficar parada, que não apareceram no período da manhã. A duração do comportamento sentada se mostra maior para a linhagem Hy-Line W36, com período de duração por volta de $12 \mathrm{~min}$. Para o comportamento de ave parada as duas linhagens não apresentaram diferenças na duração deste comportamento, ficando em média em torno de 3 min.

Um outro comportamento que aparece na parte da tarde e para a linhagem $\mathrm{Hy}$ Line W36 é o de agressividade, que teve uma duração em torno de 2 min.

\subsubsection{Tempo gasto na expressão de cada comportamento para a condição de estresse e sistema de criação em cama}

Para uma melhor análise dos tempos gastos na expressão dos comportamentos das aves para o sistema de criação em cama e para a condição de estresse térmico, são apresentadas as figuras abaixo. 


\section{LINHAGEM BROWN}

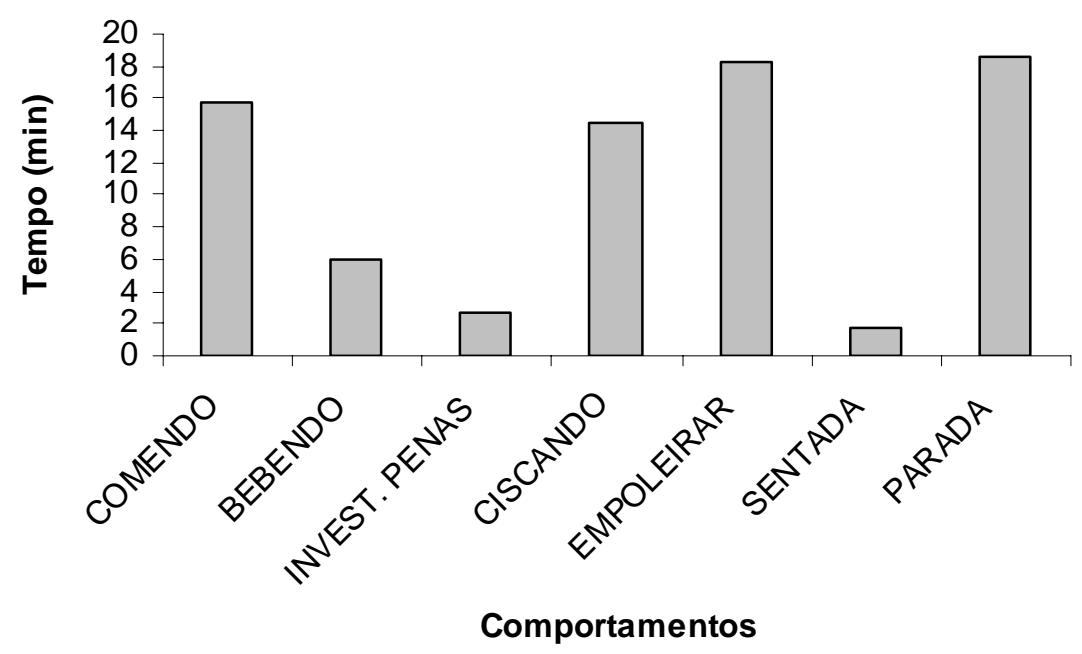

Figura 28 - Tempo médio gasto na expressão dos comportamentos da linhagem HyLine Brown no período da manhã para a condição de estresse

\section{LINHAGEM W36}

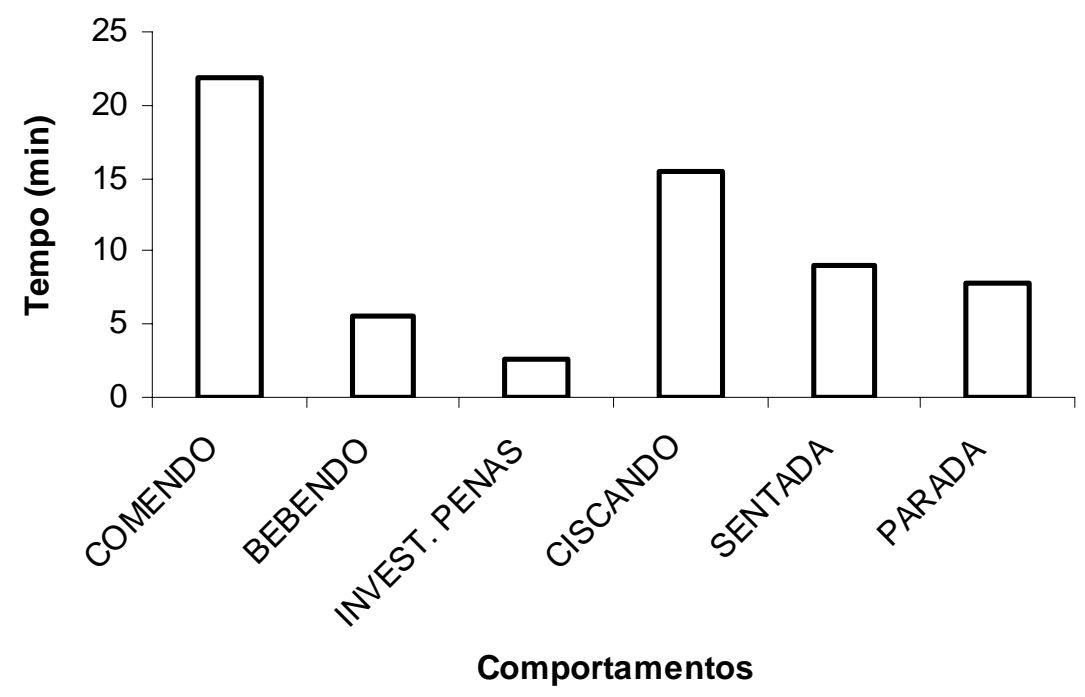

Figura 29 - Tempo médio gasto na expressão dos comportamentos da linhagem HyLine W36 no período da manhã para a condição de estresse 
LINHAGEM BROWN

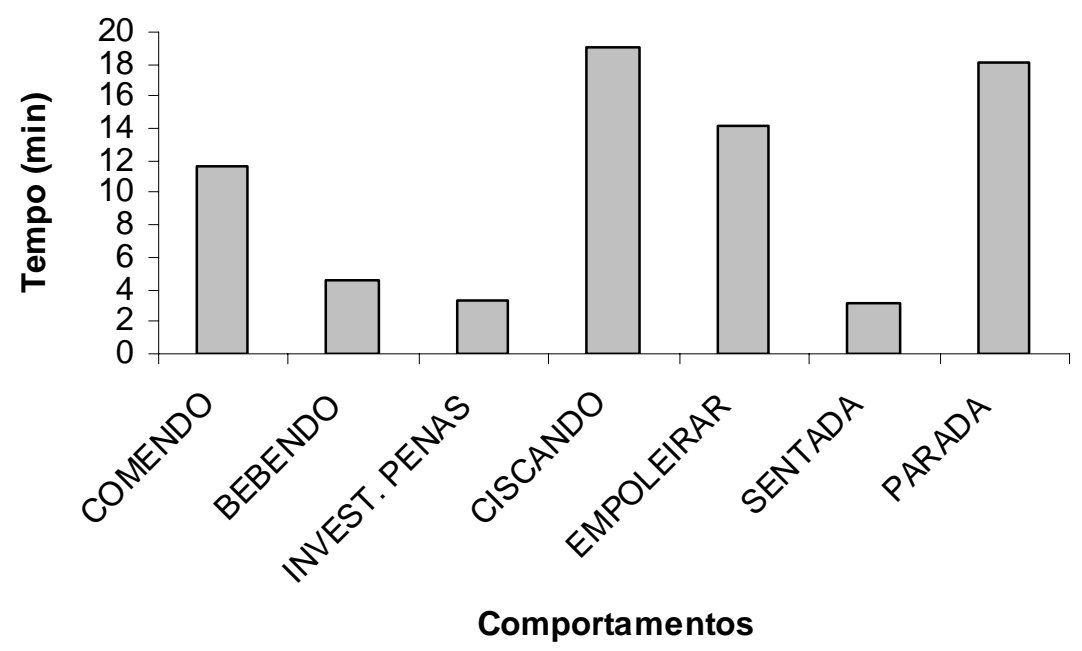

Figura 30 - Média de tempo gasto na expressão dos comportamentos da linhagem HyLine Brown no período da tarde para a condição de estresse

LINHAGEM W36

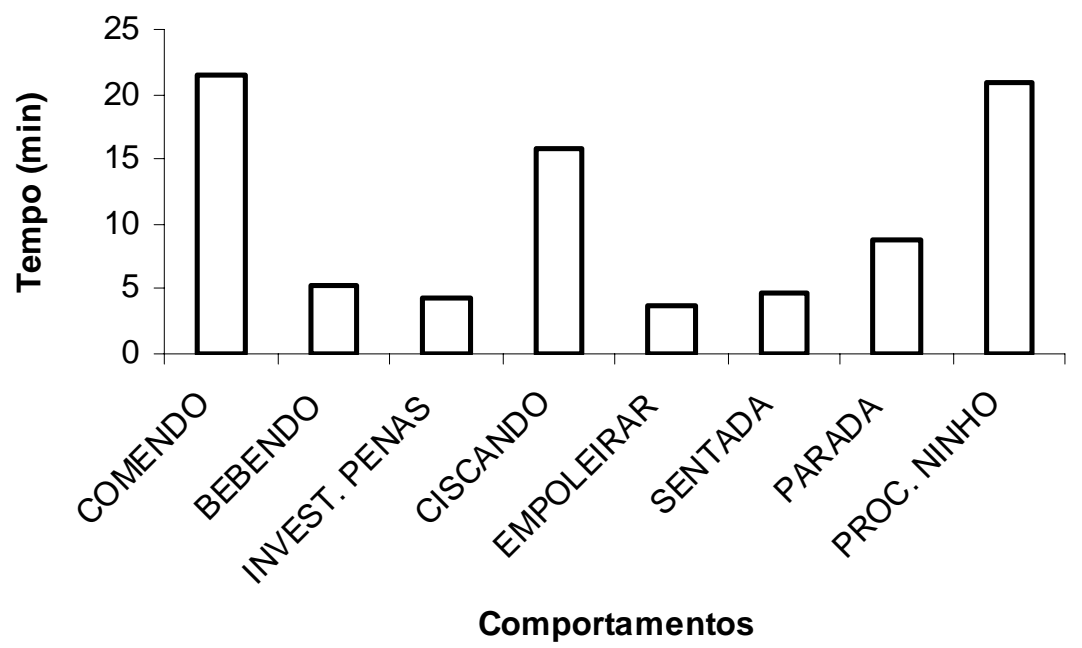

Figura 31 - Média de tempo gasto na expressão dos comportamentos da linhagem HyLine W36 no período da tarde para a condição de estresse 
Para a condição de estresse térmico, como mencionado anteriormente, há uma diminuição no tempo do comportamento de comer e um aumento no tempo do comportamento de beber água, Payne (1967); Sturkie (1967). Isso pode ser evidenciado pelos gráficos acima, em que, o tempo de duração do comportamento de beber água para ambos os períodos avaliados (manhã e tarde), ficaram em torno de 4 min. Já para o comportamento de comer há uma redução no tempo de duração deste, quando comparados os períodos da manhã e tarde, principalmente para a linhagem Hy-Line Brown, que teve o tempo reduzido de aproximadamente 15 para $11 \mathrm{~min}$, para este comportamento.

Um comportamento que também aparece para as duas linhagens analisadas é o de empoleirar, que embora seja considerado como comportamento de conforto, pode ter sido aumentado pelo fato do poleiro funcionar como um trocador de calor por condução, uma vez que, era refrigerado pela água da tubulação dos bebedouros. Sendo assim este comportamento aparece para os dois períodos avaliados, com destaque para o período da tarde em que as duas linhagens aparecem expressando este comportamento. Para o período da tarde, os tempos gastos com o comportamento de empoleirar ficaram em torno de 14 min para a linhagem Hy-Line Brown e 4 min para a linhagem Hy-Line W36.

Para o período de estresse, é possível ainda se notar um aumento nos comportamentos de ficar sentada e parada por parte das aves. Pelos gráficos é possível verificar que a linhagem Hy-Line Brown ficou mais tempo parada tanto para o período da manhã quanto para o período da tarde, com tempos de duração em torno de aproximadamente 18 min para o período da manhã e tarde. Para o comportamento de sentar, o destaque fica por conta da linhagem Hy-Line W36 no período da tarde, que praticamente dobrou o período de tempo gasto na expressão deste comportamento, passando de um tempo de 4 para 9 min.

Analisando-se ainda o período da tarde (Figuras 30 e 31), pode-se notar que a ocorrência do comportamento de pré-postura (procurar o ninho), só aconteceu para a linhagem Hy-Line W36, e teve um tempo de duração em torno de $21 \mathrm{~min}$, o que indica que, para a condição de estresse térmico, a expressão deste comportamento é afetada ou ausente, sendo que as aves entraram direto em postura pulando esta etapa ou este comportamento. 


\subsection{Avaliação da técnica de análise de imagens utilizada}

A técnica de análise de imagens utilizada nesta pesquisa, embora tenha facilitado os métodos de avaliação dos comportamentos das aves, pois possibilitou uma análise não invasiva e sem o risco de perda de comportamentos por distração do avaliador, apresentou também algumas falhas e sobre estas se faz-se necessário os seguintes comentários para aplicação em futuros estudos.

O primeiro ponto que merece ser analisado é quanto ao período e intervalo de análise necessário para uma boa avaliação dos comportamentos das aves. Nesta pesquisa foram utilizados dois dias de análise para cada condição ambiental, sendo estes dias avaliados durante uma hora no período da manhã e duas horas no período da tarde, sendo os comportamentos avaliados a cada segundo.

De acordo com Rudkin \& Stewart (2003), o tempo necessário para uma boa avaliação dos comportamentos das aves seria de 1 a 2 horas no período da manhã e de 1 a 2 horas também no período da tarde, sendo o intervalo de análise a cada 30 segundos, como um tempo ideal de avaliação de todos os comportamentos.

Quanto aos intervalos de tempo utilizados pelos autores acima, pôde ser verificado que o tempo de avaliação de 1 ou 2 horas para os períodos da manhã e tarde foram ideais, uma vez que, os comportamentos tendem a se repetir ao longo do dia e este intervalo de tempo pode ser considerado como representativo dos períodos da manhã e tarde. Quanto ao intervalo de análise de 30 em 30 segundos, durante o presente estudo, foi possível de se constatar que alguns comportamentos, tais como os movimentos de conforto ou o comportamento de beber água, na maioria das aves aconteceu de maneira muito rápida e em geral duraram menos de 30 segundos.

No entanto, pôde-se constatar que embora o tempo utilizado para a análise dos comportamentos nesta pesquisa (de segundo em segundo), tenha sido bom para uma análise de todos os comportamentos apresentados pelas aves, este teve 0 inconveniente de gerar uma grande quantidade de dados (imagens) que tinham que ser periodicamente retirados do computador e gravados em mídia (CD), devido à capacidade de armazenamento do HD.

Sendo assim, com base nas análises dos comportamentos, realizadas neste estudo, e da experiência adquirida, a sugestão é que não se adote nem o tempo que foi utilizado (a cada segundo), nem o tempo proposto na literatura (a cada 30 
segundos), recomenda-se um tempo de análise a cada 5 ou 10 segundos, isso possibilitará que praticamente todos os comportamentos possam ser detectados e que o volume final de dados não seja tão grande.

O segundo ponto a ser analisado é quanto ao correto posicionamento das câmeras de vídeo que serão instaladas para a filmagem dos comportamentos das aves. Como já foi mencionado anteriormente, durante a análise de imagens para o sistema de criação em gaiolas, o posicionamento das câmeras de vídeo (instaladas no teto da câmara climática), não possibilitou que uma análise mais criteriosa dos comportamentos das aves fosse realizada, uma vez que, a filmagem só propiciava uma vista superficial, ou seja, uma vista aérea das aves, e isso dificultou as análises de alguns comportamentos.

A recomendação é de que, para a análise dos comportamentos em sistemas abertos (sem gaiolas), a instalação das câmeras de vídeo poderá ser feita de modo a capturar a imagem aérea, pois nesse caso, como comprovado no presente estudo, não apresentará problemas relacionados à perda de comportamentos durante as análises.

Já para a filmagem de sistemas em gaiolas, as câmeras de vídeo deverão ser instaladas de modo a capturarem tanto a vista aérea quanto a vista inferior das aves, ou seja, o chão da gaiola deverá ser filmado. Quando o chão e os pés das aves puderem ser visualizados durante a análise de imagens, comportamentos como: tentativa de ciscar ou de tomar banho de areia, poderão ser avaliados de modo mais eficaz.

O terceiro e último ponto a ser analisado, é quanto a utilização de um software de interpretação e análise de imagens, para a realização de uma análise mais exata das imagens coletadas durante o período experimental. A possibilidade da utilização de um programa de computador que analisasse e interpretasse os comportamentos das aves em substituição ao método de análise visual humano, que foi utilizado nesta pesquisa, seria muito benéfico pois diminuiria o tempo de análise e possibilitaria uma análise menos subjetiva.

Trabalhos como o de Leroy et al. (2003), que utilizaram um programa de interpretação dos comportamentos das aves baseado em formas geométricas extraídas do contorno do corpo de cada ave, deverão ser cada vez mais freqüentes, uma vez que, quanto mais a tecnologia avançar e os custos de implantação dos softwares diminuírem, mais pesquisas utilizando estes recursos deverão aparecer. 


\subsection{Níveis de amônia dentro da câmara}

Talvez um dos maiores inconvenientes do sistema de criação em cama, tanto do ponto de vista sanitário como do aspecto de poluição do ambiente, seja a necessidade da utilização de um determinado tipo de substrato que possa desempenhar o papel de cama para as aves. Do ponto de vista do bem-estar animal, este material deverá ser atrativo aos animais e ao mesmo tempo não lhes causar nenhum tipo de problema sanitário, Code of Recomendations for the Welafare of Livestock - Laying Hens (2003).

O material que é geralmente utilizado como cama possui a propriedade de ser higroscópico, o que, na maioria das vezes pode se tornar um problema sério dentro dos aviários e afetar o bem-estar das aves. Dentre as causas que podem contribuir para um umedecimento da cama, estão a regulagem dos bebedouros e o teor de umidade do ambiente. Um problema decorrente desta facilidade da cama em se tornar úmida, está na fermentação do material utilizado como cama, e conseqüentemente, a liberação de amônia no ambiente, Freeman (1988).

Em se tratando de um ambiente fechado, como no caso de uma câmara climática, esta liberação de amônia é ainda mais séria e prejudicial às aves, uma vez que é difícil de ser retirada do ambiente. Durante o experimento, medidas do teor médio de amônia foram registradas no interior da câmara climática, sendo que os valores medidos ficaram em torno de 7 ppm para o período de conforto térmico e de 9 ppm para o período de estresse térmico.

Com base nos códigos de bem-estar para aves poedeiras, os níveis de amônia no ar e a altura das aves não devem ultrapassar 10 ppm. Sendo assim mesmo para o maior nível de amônia encontrado dentro da câmara e na altura das aves $(30 \mathrm{~cm})$, que ocorreu para a condição de estresse térmico ( 9 ppm), não foi prejudicial às aves.

\subsection{Mortalidade}

O índice de mortalidade verificado durante o experimento foi baixo $(7,5 \%)$, uma vez que só houve perda de aves durante o período de estresse térmico, sendo que as aves que morreram durante o período de adaptação foram substituídas por outras, e as que morreram durante o período de coleta de dados não foram substituídas. 
A maior quantidade de aves mortas (duas) ocorreu para a linhagem Hy-Line Brown no sistema de criação em gaiolas, que se mostrou menos resistente às condições de estresse térmico.

Quanto à mortalidade, outro fato importante do ponto de vista do bem-estar animal é que só ocorreram mortes no sistema de criação em gaiolas e para a condição de estresse térmico. Isso evidencia que o estresse sofrido pelas aves com relação ao espaço restrito das gaiolas e pela frustração que este sistema reflete quanto à impossibilidade de expressão dos comportamentos naturais, somado aos aspectos negativos de um ambiente com altos valores de temperatura e umidade, pode resultar na morte das aves.

\subsection{Parâmetros de qualidade dos ovos}

Os resultados obtidos nas análises dos parâmetros de qualidade dos ovos, realizadas para este estudo, apontam para uma queda na qualidade dos ovos quando as aves foram submetidas ao tratamento de estresse térmico.

Pelo quadro abaixo é possível visualizar melhor as médias dos valores dos parâmetros de qualidade dos ovos, por meio da comparação das médias, pelo teste Tukey $(P<0,05)$. 


\begin{tabular}{|c|c|c|c|c|c|c|c|}
\hline & \multicolumn{5}{|c|}{ Parâmetros de qualidade } \\
\hline & & & Peso & $\begin{array}{l}\text { Gravidade } \\
\text { especifica }\end{array}$ & $\begin{array}{c}\text { Unidade } \\
\text { Haugh }\end{array}$ & $\begin{array}{c}\text { Espessura } \\
\text { da casca }\end{array}$ & $\begin{array}{c}\text { Índice de } \\
\text { gema }\end{array}$ \\
\hline \multirow{4}{*}{ Conforto } & \multirow{2}{*}{ Linhagem } & W36 & $55,5 a$ & $1,0917 a$ & $102,0 \mathrm{a}$ & $45,8 a$ & $0,41 a$ \\
\hline & & Brown & $57,8 a$ & $1,0897 a$ & $105,4 b$ & $43,7 c$ & $0,43 a$ \\
\hline & \multirow{2}{*}{ Sistema } & Cama & $54,7 a$ & $1,0912 a$ & $104,0 \mathrm{a}$ & $45,1 \mathrm{a}$ & $0,42 \mathrm{ac}$ \\
\hline & & Gaiola & $55,5 a$ & $1,0902 a$ & $103,4 \mathrm{ac}$ & $44,4 a$ & $0,42 \mathrm{ac}$ \\
\hline \multirow{4}{*}{ Estresse } & \multirow{2}{*}{ Linhagem } & W36 & $51,8 b$ & $1,0772 b$ & $100,3 a$ & $38,3 b$ & $0,39 c$ \\
\hline & & Brown & $52,7 a b$ & $1,0775 b$ & $101,6 a$ & $36,8 d$ & $0,41 a$ \\
\hline & \multirow[b]{2}{*}{ Sistema } & Cama & $53,5 a$ & $1,0777 b$ & $100,8 b$ & $38,3 b$ & 0,41 acd \\
\hline & & Gaiola & $51,0 a$ & $1,0770 b$ & $101,1 b c$ & $36,8 c$ & $0,40 \mathrm{bcd}$ \\
\hline \multirow{4}{*}{ Linhagem } & \multirow[b]{2}{*}{ W36 } & Cama & $53,9 a$ & $1,0837 a$ & $101,2 \mathrm{ac}$ & $42,4 \mathrm{ad}$ & $0,40 a$ \\
\hline & & Gaiola & $53,3 a$ & $1,0852 a b$ & $101,1 \mathrm{ac}$ & $41,7 \mathrm{ad}$ & $0,41 a$ \\
\hline & \multirow{2}{*}{ Brown } & Cama & $54,3 a$ & $1,0852 a b$ & $103,6 b c$ & $41,0 \mathrm{bd}$ & $0,44 b$ \\
\hline & & Gaiola & $53,1 \mathrm{a}$ & $1,0820 \mathrm{ac}$ & $103,4 a c$ & $39,5 c$ & $0,41 a$ \\
\hline
\end{tabular}

a,b,c - médias seguidas pelas mesmas letras, para uma mesma coluna, não diferem entre si pelo teste Tukey $(\mathrm{P}<0,05)$.

Quadro 4 - Comparação das médias dos parâmetros de qualidade dos ovos

4.9.1 Peso dos ovos: A análise estatística das médias dos pesos dos ovos revelou uma diferença significativa deste parâmetro de qualidade com relação à condição ambiental e à interação sistema de criação e condição ambiental.

Conforme o Quadro 4 acima, houve uma redução significativa $(P<0,05)$ no peso dos ovos quando as aves foram submetidas às condições de estresse térmico. Estes resultados confirmam os encontrados por diversos autores como Huston et al. (1957); Mueller (1961); De Andrade et al. (1976); Belnave \& Muheereza (1997); Mashaly et al. 
(2004) e Carmon \& Huston (1965), que encontraram uma diferença de 7,5 gramas entre ovos postos sob condições de conforto e estresse térmico.

Nesta pesquisa, as diferenças médias de peso dos ovos, quando se comparou as duas condições ambientais propostas, foram de: $3,2 \mathrm{~g}$ e 2,4 $\mathrm{g}$ para a linhagem HyLine Brown, respectivamente para o sistema em cama e para o sistema de criação em gaiolas. Para a linhagem Hy-Line W36 a redução média no peso dos ovos foi de 3,6 g e de 7,2 g, respectivamente, para o sistema em cama e para o sistema em gaiolas.

A Figura 32 abaixo mostra o comportamento do parâmetro de qualidade peso do ovo $(\mathrm{g})$, para a condição de conforto e estresse térmico.

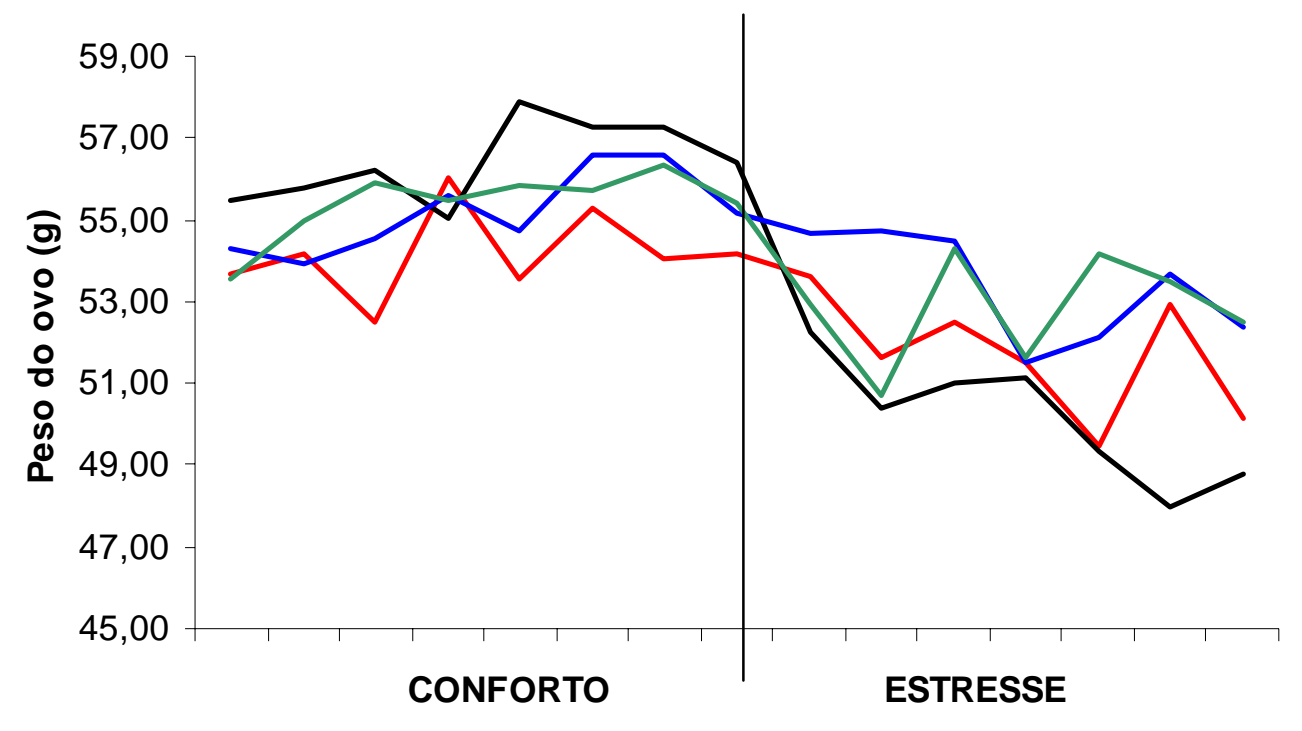

— GaiolaBrown — GaiolaW36 CamaBrown —CamaW36

Figura 32 - Médias dos pesos dos ovos para as condições de ambiente de conforto e de estresse

Pela Figura 32, é possível notar uma queda nos valores médios de peso dos ovos, quando a condição ambiental passa de conforto para estresse térmico. Pelo comportamento das curvas, é possível observar também uma queda mais expressiva das médias de peso dos ovos que para a condição de criação em gaiola, o que pode ser explicado, provavelmente, pelo maior estresse que este sistema apresenta em condições de altas temperaturas, tendo-se em vista o grau de confinamento e a maior dificuldade das aves em perder calor. 
Quanto às linhagens estudadas, a linhagem Hy-Line W36, no sistema de criação em gaiolas, foi a que apresentou a maior queda nos valores de peso dos ovos $(7,2 \mathrm{~g})$ sob condições de estresse térmico, o que se torna uma informação muito útil para a indústria produtora de ovos, uma vez que, esta é uma linhagem muito utilizada pelos produtores, e estes deverão estar sempre atentos às condições ambientais, uma vez que estas terão uma influência direta na qualidade da produção de ovos.

4.9.2 Gravidade específica: Quanto ao parâmetro gravidade especifica dos ovos, observa-se também pelo gráfico e pelo Quadro 4 acima, uma redução significativa $(\mathrm{P}<0,05)$ das médias dos valores avaliados, com relação à linhagem, sistema de criação e condição ambiental.

Observando-se a Figura 33 abaixo, é possível notar uma queda nos valores médios de gravidade especifica dos ovos para a condição ambiental de estresse térmico. Esta queda pode ser explicada por fatores como a queda no peso dos ovos e alterações na espessura da casca.

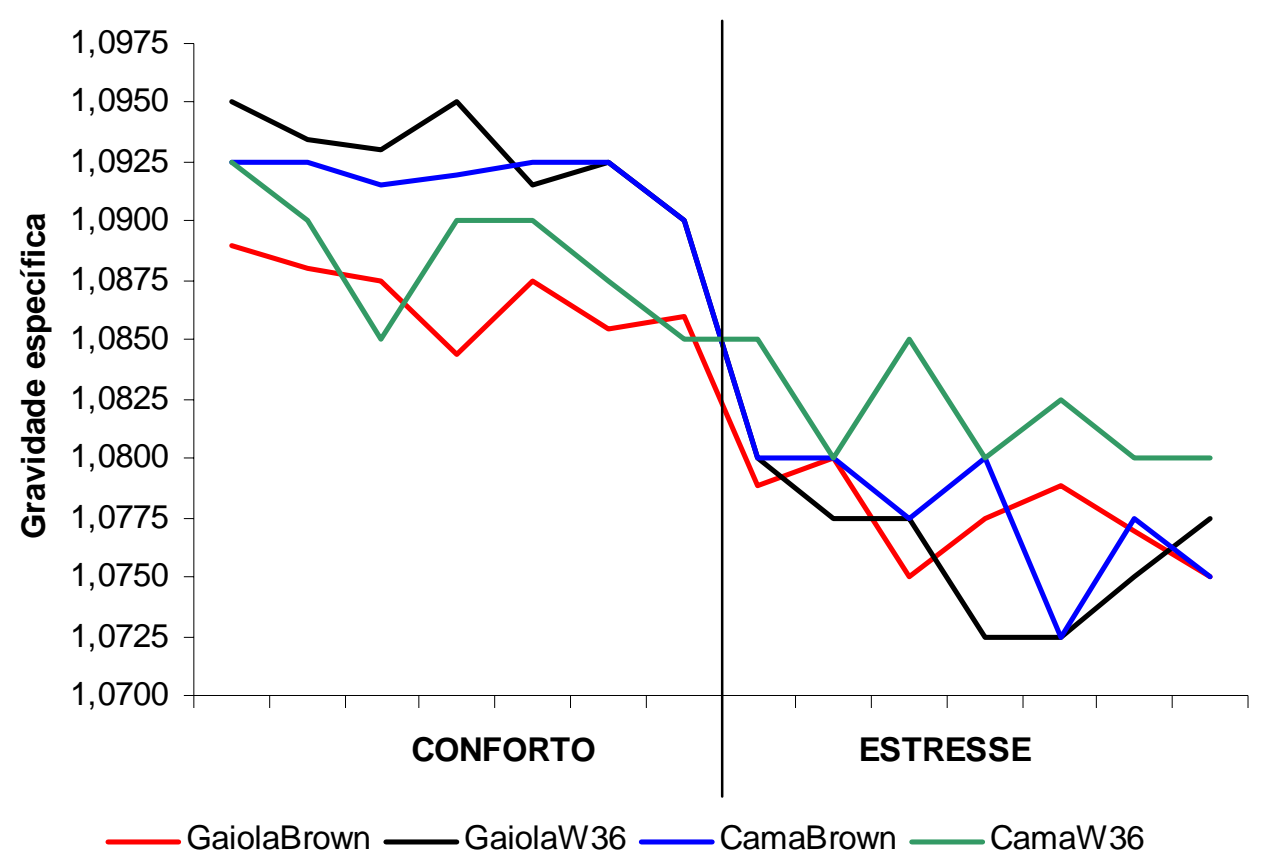

Figura 33 - Médias dos valores de gravidade especifica para as condições de ambiente de conforto e de estresse 
Para as condições de criação avaliadas, pôde-se verificar uma queda maior nos valores médios de gravidade específica para a condição de criação em gaiolas, que pode ser explicada novamente pelas maiores taxas de estresse a que estas aves são expostas.

Para as linhagens avaliadas, a que apresentou uma maior queda dos valores de gravidade específica sob condições de estresse térmico, foi a linhagem Hy-Line W36 criada em gaiola, mais uma vez um dado de muita importância para toda a cadeia de produção de ovos.

O parâmetro de qualidade gravidade especifica está intimamente relacionado à qualidade da casca dos ovos, segundo Hamilton (1982), a gravidade específica aumenta a medida que a espessura da casca aumenta, este fato também pôde ser constatado nesta pesquisa, uma vez que, como pode-se verificar pelo Quadro 4, quanto maior o valor de espessura de casca maior o valor da gravidade específica.

Ainda sobre valores de gravidade específica, Peebles \& McDaniel (2004) consideraram em seu trabalho o valor de gravidade especifica 1,0800 como um valor limite entre baixa ou alta qualidade da casca dos ovos. Observando o Quadro 4, é possível verificar que este valor limite de gravidade específica foi atingido para as duas linhagens estudadas, mais somente para a condição ambiental de conforto.

Quanto à importância do parâmetro de qualidade gravidade específica, para o produtor de ovos, é que este está diretamente ligado às qualidades da casca dos ovos, que por sua vez é mais difícil de ser medida do que quando comparado com a medida da gravidade específica, pois além de ser um método rápido e fácil, não destrutivo e que fornece uma melhor caracterização da qualidade.

4.9.3 Unidades Haugh: O parâmetro de qualidade unidades Haugh apresentou uma diferença significativa $(P<0,05)$ com relação à linhagem e as condições ambientais estudadas.

Para a condição ambiental de estresse térmico, o parâmetro de qualidade unidades Haugh teve uma queda significativa em seus valores, o que pode ser decorrente do estresse sofrido pelas aves devido aos efeitos das altas temperaturas. Este resultado confirma o encontrado por Kirunda et al. (2001), que relatou em seu trabalho que os valores de unidade Haugh diminuíram em relação aos encontrados antes da exposição das aves ao estresse térmico. 
Quanto aos sistemas de criação, o parâmetro unidades Haugh apresentou uma queda para os ovos postos no sistema de criação em gaiolas, o que reafirma mais uma vez uma condição mais estressante deste sistema.

A linhagem Hy-Line W36 teve uma menor média de valores de unidades Haugh durante o período de estresse térmico, confirmando seu desempenho inferior em relação à linhagem Hy-Line Brown quanto aos parâmetros de qualidade dos ovos.

É importante mencionar que, mesmo com desempenho inferior, os ovos da linhagem Hy-Line W36 foram classificados, segundo as normas internacionais, como ovos do tipo AA, assim também como os ovos da linhagem Hy-Line Brown, independentemente da condição ambiental e do sistema de criação, ou seja, ovos com excelente qualidade do ponto de vista do parâmetro albúmen.

Certamente o fato de, mesmo estando sob condição de estresse térmico, as aves terem apresentado uma ótima qualidade do parâmetro albúmen, possa estar relacionado com a idade das aves utilizadas nesta pesquisa (inicio de postura), o que está de acordo com Souza et al. (1994), que concluíram que ovos provenientes de aves em início de postura apresentaram valores mais altos de unidades Haugh.

4.9.4 Porcentagem de constituintes: A porcentagem de constituintes dos ovos, ou seja, as porcentagens de casca, albúmen e gema dos ovos apresentaram diferenças significativas $(P<0,05)$ para as linhagens, sistemas de criação e condições ambientais avaliados.

Porcentagem de casca - Para os valores médios de porcentagem de casca é possível verificar pelas Tabelas 6 e 7 abaixo, que não houve diferença significativa nos valores de porcentagem de casca dentro de uma mesma linhagem para os dois sistemas de criação e para as condições ambientais avaliadas, sendo a linhagem HyLine Brown a que apresentou as menores médias de porcentagem de casca para ambos os sistemas de criação e condições ambientais.

Pela Tabela 6 é possível notar que o menor valor médio de porcentagem de casca ocorre para a linhagem Hy-Line Brown em sistema de gaiolas, o que indica que certamente esta linhagem é mais susceptível aos efeitos negativos de estresse que este sistema apresenta. 
Tabela 6. Porcentagem média de casca, para as duas linhagens e sistemas de criação

\begin{tabular}{ccc}
\hline Linhagem & Sistema & \% casca \\
\hline \multirow{2}{*}{ W36 } & Cama & $9,47 \mathrm{a}$ \\
& Gaiola & $9,36 \mathrm{ab}$ \\
\multirow{2}{*}{ Brown } & Cama & $9,10 \mathrm{bc}$ \\
& Gaiola & $8,77 \mathrm{c}$ \\
\hline
\end{tabular}

a,b,c - médias seguidas pelas mesmas letras não diferem entre si pelo teste Tukey $(P<0,05)$.

Tabela 7. Porcentagem média de casca, para as duas linhagens e condições ambientais

\begin{tabular}{ccc}
\hline Linhagem & Condição & \% casca \\
\hline \multirow{2}{*}{ W36 } & Conforto & $10,20 \mathrm{a}$ \\
& Estresse & $8,60 \mathrm{~b}$ \\
\multirow{2}{*}{ Brown } & Conforto & $9,80 \mathrm{c}$ \\
& Estresse & $8,10 \mathrm{~d}$ \\
\hline
\end{tabular}

a,b,c - médias seguidas pelas mesmas letras não diferem entre si pelo teste Tukey $(P<0,05)$.

Com relação à Tabela 7, é possível notar um desempenho inferior das linhagens quanto ao parâmetro de qualidade em questão, para a condição de estresse térmico, principalmente para a linhagem Hy-Line Brown que se mostrou novamente a de menor desempenho quanto a este parâmetro. Sendo assim verifica-se a importância de um bom condicionamento térmico do local onde as aves se encontram, para que perdas de produção devido a ovos quebrados ou trincados resultantes de baixos valores de porcentagem de casca não venham a ocorrer.

Comparando-se as condições ambientais e os sistemas de criação, pode-se observar pela Tabela 8 abaixo, que para a condição de estresse térmico ocorre uma redução significativa nos valores médios de porcentagem de casca quando se comparam os dois tipos de sistemas de criação.

Novamente a queda nos valores de porcentagem de casca pode ser explicada pela maior carga de estresse a que as aves criadas no sistema de gaiolas são submetidas, além do fato de que neste sistema o estresse térmico é mais acentuado, devido às condições de confinamento das aves que dificultam as perdas de calor. 
Tabela 8. Porcentagem média de casca, para os dois sistemas de criação e condições ambientais

\begin{tabular}{ccc}
\hline Sistema & Condição & \% casca \\
\hline \multirow{2}{*}{ Cama } & Conforto & $10,0 \mathrm{a}$ \\
& Estresse & $8,5 \mathrm{~b}$ \\
\multirow{2}{*}{ Gaiola } & Conforto & $9,9 \mathrm{a}$ \\
& Estresse & $8,2 \mathrm{~b}$ \\
\hline
\end{tabular}

a,b - médias seguidas pelas mesmas letras não diferem entre si pelo teste Tukey $(P<0,05)$.

Porcentagem de albúmen - Para os valores médios de porcentagem de albúmen é possível se verificar pela Tabela 9 abaixo, que não houve diferença significativa nos valores de porcentagem de albúmen dentro de uma mesma linhagem para as condições ambientais avaliadas (conforto e estresse), sendo a linhagem Hy-Line W36 a que apresentou as menores médias de porcentagem de albúmen para ambas as condições ambientais avaliadas.

Tabela 9. Porcentagem média de albúmen, para as duas linhagens e condições ambientais

\begin{tabular}{|c|c|c|}
\hline Sistema & Condição & \% Albumen \\
\hline \multirow{2}{*}{ Cama } & Conforto & $67,7 \mathrm{a}$ \\
\hline & Estresse & $67,8 \mathrm{a}$ \\
\hline \multirow{2}{*}{ Gaiola } & Conforto & 67,6 a \\
\hline & Estresse & $66,5 \mathrm{~b}$ \\
\hline
\end{tabular}

Pela Tabela 10 é possível verificar para a linhagem Hy-Line W36 uma diferença estatística entre as médias de porcentagem de albúmen para os diferentes sistemas de criação, ou seja, para o sistema de criação em cama a porcentagem média de albúmen foi maior do que para o sistema de criação em gaiola.

Analisando-se a Tabela 11 abaixo, pode-se observar que o já vem sendo sempre relatado neste trabalho, ou seja, o pior desempenho do sistema de criação em gaiola juntamente com a condição de estresse térmico. 
Tabela 10. Porcentagem média de albúmen, para as duas linhagens e sistemas de criação

\begin{tabular}{ccc}
\hline Linhagem & Sistema & \% Albumen \\
\hline \multirow{2}{*}{ W36 } & Cama & $67,0 \mathrm{a}$ \\
& Gaiola & $66,0 \mathrm{~b}$ \\
\multirow{2}{*}{ Brown } & Cama & $68,4 \mathrm{c}$ \\
& Gaiola & $68,1 \mathrm{c}$ \\
\hline
\end{tabular}

a,b - médias seguidas pelas mesmas letras não diferem entre si pelo teste Tukey $(P<0,05)$.

Tabela 11. Porcentagem média de albúmen, para os dois sistemas de criação e condições ambientais

\begin{tabular}{ccc}
\hline Linhagem & Condição & \% Albumen \\
\hline \multirow{2}{*}{ W36 } & Conforto & $66,8 \mathrm{a}$ \\
& Estresse & $66,2 \mathrm{a}$ \\
\multirow{2}{*}{ Brown } & Conforto & $68,5 \mathrm{~b}$ \\
& Estresse & $68,0 \mathrm{~b}$ \\
\hline
\end{tabular}

${ }^{a, b}$ - médias seguidas pelas mesmas letras não diferem entre si pelo teste Tukey $(P<0,05)$.

Porcentagem de gema - Pela Tabela 12 abaixo, pode-se observar que houve diferença significativa nos valores de porcentagem de gema dentro de uma mesma linhagem para os sistemas de criação avaliados (cama e gaiola), sendo a linhagem HyLine Brown a que apresentou as menores médias de porcentagem deste parâmetro para ambas as condições de criação avaliadas.

Tabela 12. Porcentagem média de gema, para as duas linhagens e sistemas de criação

\begin{tabular}{ccc}
\hline Linhagem & Sistema & \% Gema \\
\hline \multirow{2}{*}{ W36 } & Cama & $23,4 \mathrm{a}$ \\
& Gaiola & $24,6 \mathrm{~b}$ \\
\multirow{2}{*}{ Brown } & Cama & $22,4 \mathrm{c}$ \\
& Gaiola & $23,0 \mathrm{ac}$ \\
\hline
\end{tabular}

a,b,c - médias seguidas pelas mesmas letras não diferem entre si pelo teste Tukey $(P<0,05)$.

Observando-se a Tabela 13 abaixo, nota-se novamente um pior desempenho da linhagem Hy-Line Brown em condições de estresse térmico quanto ao parâmetro de qualidade porcentagem de gema. 
Tabela 13. Porcentagem média de albúmen, para as duas linhagens e condições ambientais

\begin{tabular}{ccc}
\hline Linhagem & Condição & \% Gema \\
\hline \multirow{2}{*}{ W36 } & Conforto & $22,9 \mathrm{a}$ \\
& Estresse & $25,1 \mathrm{~b}$ \\
\multirow{2}{*}{ Brown } & Conforto & $21,6 \mathrm{c}$ \\
& Estresse & $23,8 \mathrm{~d}$ \\
\hline
\end{tabular}

a,b,c - médias seguidas pelas mesmas letras não diferem entre si pelo teste Tukey $(P<0,05)$.

Tabela 14. Porcentagem média de albúmen, para os dois sistemas de criação e condições ambientais

\begin{tabular}{ccc}
\hline Sistema & Condição & \% Gema \\
\hline \multirow{2}{*}{ Cama } & Conforto & 22,2 a \\
& Estresse & 23,6 b \\
\multirow{2}{*}{ Gaiola } & Conforto & 22,4 a \\
& Estresse & 25,2 c \\
\hline
\end{tabular}

a,b,c - médias seguidas pelas mesmas letras não diferem entre si pelo teste Tukey $(P<0,05)$.

A Tabela 14 acima, mostra que houve diferença significativa $(P<0,05)$, para os dois sistemas de criação durante com relação a condição de estresse térmico, no entanto pode-se constatar também que os valores médios de porcentagem de gema foram maiores para o sistema de criação em gaiolas tanto para a condição de conforto quanto para a condição de estresse.

4.9.5 Espessura da casca: Para este parâmetro, houve diferenças significativas $(P<0,05)$, quanto à linhagem, sistema de criação e condição ambiental (Tabela 9$)$.

Observando-se a Figura 34 abaixo, pode-se notar uma queda bem acentuada nos valores médios de espessura da casca dos ovos durante o período de estresse térmico. Isso de acordo com autores como Emery et al. (1984) e Mahmoud et al. (1996), é decorrente da diminuição no balaço de cálcio no sangue, uma vez que se sabe que este balanço é afetado quando a ave se encontra em condições de altas temperaturas, diminuindo a quantidade de plasma cálcico e comprometendo a formação da casca do ovo. 


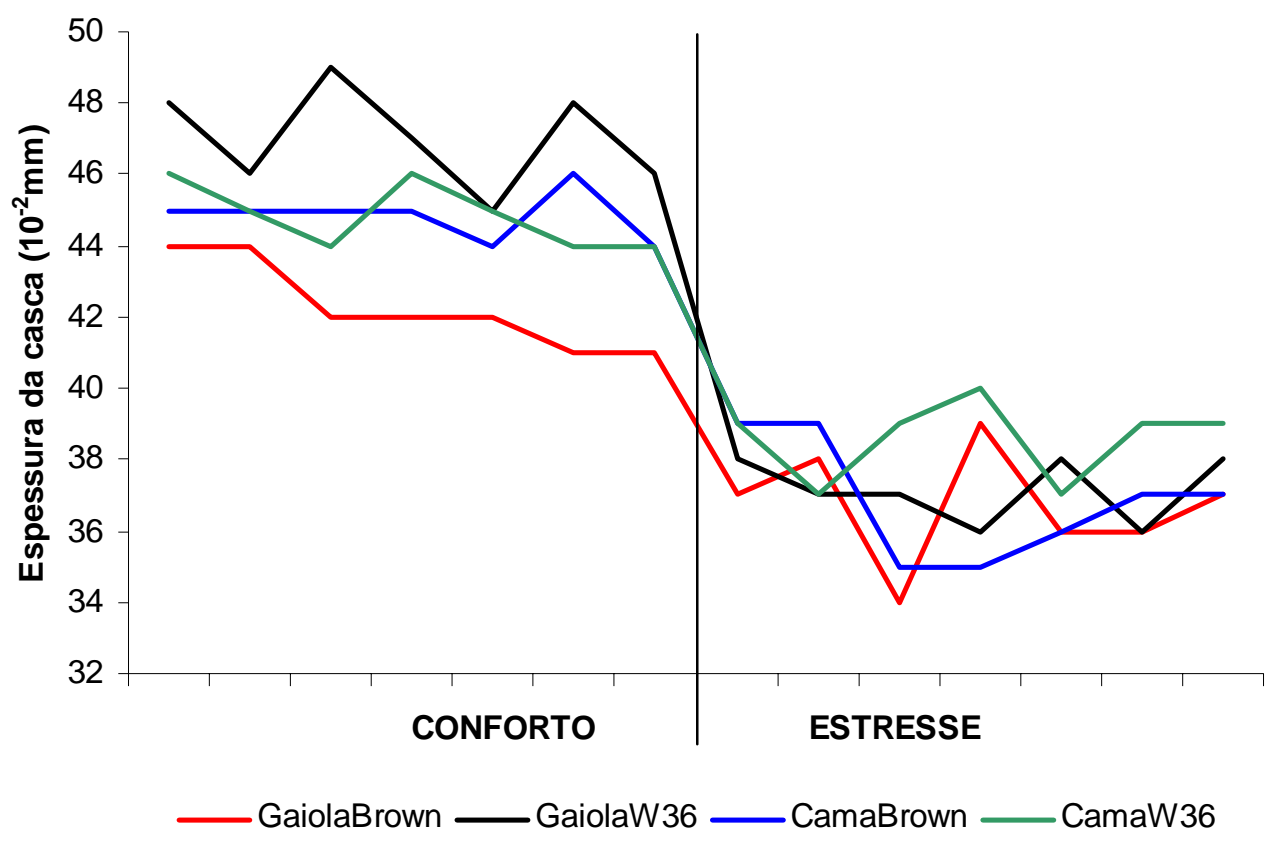

Figura 34 - Médias dos valores de espessura da casca dos ovos para as condições de ambiente de conforto e estresse

Segundo Pereira (1991), a queda do pH sangüíneo, decorrente da alcalose respiratória provocada pelo estresse térmico, faz com que ocorra uma queda no cálcio disponível no sangue para a formação da casca, resultando, assim, em problemas de qualidade de casca.

Quanto às condições de criação avaliadas, de modo geral o sistema de criação em gaiolas foi o que apresentou uma maior queda nos valores médios de espessura da casca, comprovando mais uma vez os efeitos negativos deste sistema de criação com relação aos parâmetros de qualidade dos ovos.

Com relação às linhagens avaliadas, a que apresentou uma maior queda nos valores do parâmetro de qualidade em questão foi novamente a linhagem Hy-Line Brown, criada tanto para a condição de estresse térmico quanto para o sistema de criação em gaiolas.

O parâmetro de qualidade espessura de casca é também é de grande interesse para os produtores de ovos, uma vez que problemas como, perdas de ovos por quebra ou rachaduras poderão trazer prejuízos, além de indicarem também que 
provavelmente este problema esteja ocorrendo devido a falhas de ambiência dentro das instalações onde as aves se encontram.

Segundo Jacob et al. (2000), problemas na casca poderão também resultar em uma baixa classificação dos ovos, o que poderá causar uma desvalorização do produto no mercado.

\subsubsection{Colorimetria da gema:}

O mundo ao redor do indivíduo é percebido pelos sentidos. Destes, a visão é o mais marcante, sendo definido não apenas pela forma e aspecto dos objetos, mas também pela cor, que na maioria das vezes, é o primeiro critério utilizado na aceitação ou rejeição de um objeto ou alimento. Por isso, na indústria de alimentos a cor é atributo importante, Batista (1994).

A pigmentação amarela da gema do ovo se deve ao consumo de dietas que incluem substâncias hidroxicarotenóides, chamadas xantofilas. Estes pigmentos não são sintetizados pelas aves e devem ser incorporados às rações, Araya et al. (1977).

O milho possui cerca de $25 \mathrm{mg}$ de xantofila por $\mathrm{kg}$, que tende a decrescer durante a estocagem. Existem ainda compostos sintéticos à base de éter apocarotenóico (amarelo) e Cataxantina (vermelho), que são misturados à ração em pequenas quantidades, para dar pigmentação adequada de acordo com as exigências do mercado de ovos, Englert (1987).

As análises de cor de gema normalmente são efetuadas através do leque colorimétrico ROCHE, numa escala de valores de 1 a 15 (do amarelo claro ao cor de abóbora respectivamente), no entanto esta metodologia é muito subjetiva. Sendo assim optou-se pela determinação da colorimetria da gema através do aparelho colorímetro Minolta, o que possibilitou uma medida mais exata deste parâmetro.

No Quadro 5 abaixo são apresentados os valores médios dos componentes L, a e b, onde: o valor de a caracteriza coloração na região do vermelho (+a) ao verde (a), o valor b indica coloração no intervalo do amarelo $(+\mathbf{b})$ ao azul $(-\mathbf{b})$ e o valor $\mathbf{L}$ que se refere a luminosidade, variando do branco $(\mathbf{L}=100)$ ao preto $(\mathbf{L}=0)$. Como pode ser verificado nos prismas de cor em anexo (Anexo $\mathrm{M} \mathrm{e} \mathrm{N}$ ). 


\begin{tabular}{|c|c|c|c|c|c|}
\hline & \multicolumn{3}{|c|}{ Colorimetria } \\
\hline & & & L & $a$ & $b$ \\
\hline \multirow{4}{*}{ Conforto } & \multirow{2}{*}{ Linhagem } & W36 & $62,6 a$ & $0,12 a$ & $46,4 a$ \\
\hline & & Brown & $64,5 a$ & $-1,83 a b$ & $49,1 \mathrm{a}$ \\
\hline & \multirow{2}{*}{ Sistema } & Cama & $63,8 a$ & $-2,18 a c$ & $44,8 a c$ \\
\hline & & Gaiola & $53,4 a$ & $0,47 b c$ & $50,7 \mathrm{bc}$ \\
\hline \multirow{4}{*}{ Estresse } & \multirow{2}{*}{ Linhagem } & W36 & $61,4 a$ & $-0,05 a$ & $51,0 a$ \\
\hline & & Brown & $62,4 a$ & $-2,68 b$ & $47,5 \mathrm{a}$ \\
\hline & \multirow{2}{*}{ Sistema } & Cama & $52,8 \mathrm{a}$ & $-1,58 \mathrm{ac}$ & $48,3 a c$ \\
\hline & & Gaiola & $51,0 a$ & $-1,15 a c$ & $50,2 b c$ \\
\hline \multirow{4}{*}{ Linhagem } & \multirow{2}{*}{ W36 } & Cama & $62,7 a$ & $-0,89 a b$ & $46,8 a$ \\
\hline & & Gaiola & $61,3 a$ & $0,96 a b$ & $50,7 a$ \\
\hline & \multirow{2}{*}{ Brown } & Cama & $63,9 a$ & $-2,87 a c$ & $46,4 a$ \\
\hline & & Gaiola & $63,1 \mathrm{a}$ & $-1,64 \mathrm{ac}$ & $50,2 a$ \\
\hline
\end{tabular}

a,b,c - médias seguidas pelas mesmas letras, na mesma coluna, não diferem entre si pelo teste Tukey $(\mathrm{P}<0,05)$.

Quadro 5 - Valores médios de $\mathbf{L}$, a e b medidos para as gemas dos ovos para as diferentes linhagens, condições ambientais e sistemas de criação

O intuito se analisar os ovos quanto a colorimetria da gema nesta pesquisa, foi mais direcionada para o levantamento de uma característica sensorial dos mesmos, uma vez que sabe-se que a cor da gema é fortemente relacionada com os aspectos nutricionais das aves Araya et al. (1977).

Pela análise do quadro acima, é possível constatar que não ocorrem mudanças significativas nos valores das médias dos parâmetros de colorimetria avaliados, o que, reforça a afirmação de que aparentemente a cor da gema não esta relacionada com 
mudanças ambientais e nem com os sistemas de criação das aves, mais sim com aspectos ligados à composição da ração que é fornecida as aves.

Dessa maneira o produtor de ovos deverá adequar as características da formulação da ração, adicionando ou retirando pigmentantes para que possa atender as exigências de cor de gema do mercado. Araya et al. (1977).

4.9.7 Índice de gema (IG): Para este parâmetro houve diferenças significativas $(\mathrm{P}<0,05)$, quanto à linhagem, condição ambiental e sistema de criação.

Pelo Quadro 4 é possível notar uma queda significativa $(\mathrm{P}<0,05)$ nos valores médios de IG para a linhagem Hy-Line W36 para a condição de estresse térmico. Para a linhagem W36 é possível notar ainda que não houve diferença estatística quanto aos sistemas de criação avaliados.

Quanto a linhagem Hy-Line Brown, não houve diferença para este parâmetro de qualidade entre as condições ambientais avaliadas. No entanto, quando se analisa o valor médio de IG para os sistemas de criação avaliados é possível se verificar que ocorre uma redução significativa $(P<0,05)$ nos valores de IG para a linhagem Hy-Line Brown e para o sistema de criação em gaiola.

4.9.8 Porosidade da casca: Para este parâmetro houve diferenças significativas quanto à linhagem e condição ambiental, como se pode observar na Tabela 15 abaixo.

Tabela 15. Porosidade média $\left(\mathrm{n}^{\circ}\right.$ poros $\left./ 0,4 \mathrm{~cm}^{2}\right)$, para as condições ambientais e de sistemas de criação avaliados

\begin{tabular}{cccc}
\hline Linhagem & Ambiente & Sist. Criação & Média Poros \\
\hline \multirow{4}{*}{ W36 } & \multirow{2}{*}{ Conforto } & Cama & $80,6 \mathrm{a}$ \\
& & Gaiola & $82,3 \mathrm{a}$ \\
& \multirow{2}{*}{ Estresse } & Cama & $56,6 \mathrm{~b}$ \\
& & Gaiola & $51,6 \mathrm{~b}$ \\
& & Cama & $84,3 \mathrm{a}$ \\
Brown & \multirow{2}{*}{ Conforto } & Gaiola & $87,6 \mathrm{a}$ \\
& \multirow{2}{*}{ Estresse } & Cama & $86,0 \mathrm{a}$ \\
& & Gaiola & $72,3 \mathrm{a}$ \\
\hline
\end{tabular}

a,b - médias seguidas pelas mesmas letras não diferem entre si pelo teste Tukey $(P<0,05)$. 
O parâmetro porosidade da casca tem uma maior importância quando os ovos são produzidos ou destinados à produção de pintos, uma vez que, conforme Ar et al. (1974) citados por Peebles \& Brake (1985), a porosidade tem uma relação direta com a qualidade do embrião produzido.

Para o enfoque desta pesquisa, que não é o da produção de ovos para a reprodução, talvez seja interessante que o parâmetro porosidade seja interpretado de outra maneira, ou seja, enquanto para o aspecto de reprodução é interessante que a casca dos ovos seja porosa para garantir um desenvolvimento adequado do embrião, para o aspecto de qualidade sob o ponto de vista de consumo do alimento ovo, talvez fosse mais interessante que a casca fosse menos porosa, pois isso com certeza influenciaria na qualidade interna dos ovos, uma vez que, os poros são a única comunicação entre o interior dos ovos e o ambiente exterior, que neste caso poderia ser a cama ou o piso de arame das gaiolas.

Avaliando as duas linhagens sob este aspecto, é possível se verificar pela Tabela 15 que a única diferença nos valores médios de quantidade de poros nas cascas dos ovos foi verificada para a linhagem Hy-Line W36, sob condição de estresse térmico, o que poderia ser interpretado como uma melhor qualidade deste parâmetro em comparação com a linhagem Hy-line Brown.

4.9.9 Qualidade visual dos ovos: A qualidade visual dos ovos foi definida por análises externas visuais e por análise interna e externa dos ovos por meio da ovoscopia.

Tabela 16. Porcentagem de ovos limpos, sujos e quebrados avaliados visivelmente

\begin{tabular}{cccccc}
\cline { 3 - 5 } & & & \multicolumn{3}{c}{ \% Ovos } \\
\hline Condição & Linhagem & Sistema & Limpos & Sujos & Quebrados \\
\hline \multirow{4}{*}{ Conforto } & \multirow{2}{*}{ W36 } & Cama & 97 & 3 & 0 \\
& & Gaiola & 94 & 6 & 1 \\
& \multirow{6}{*}{ Brown } & Cama & 98 & 2 & 0 \\
& & Gaiola & 94 & 6 & 2 \\
Estresse & \multirow{2}{*}{ W36 } & Cama & 97 & 3 & 0 \\
& & Gaiola & 90 & 10 & 8 \\
& \multirow{2}{*}{ Brown } & Cama & 99 & 1 & 0 \\
& & Gaiola & 91 & 9 & 10 \\
\hline
\end{tabular}


Analisando a Tabela 16, pode-se notar que para a condição de ambiente de conforto, o sistema de criação em cama apresentou uma quantidade de ovos sujos menor do que para a condição de criação em sistema de gaiolas, e por sua vez também nenhuma ocorrência de ovos quebrados, o que indica um melhor desempenho deste tipo de sistema de criação com relação ao sistema convencional, sob o ponto de vista de qualidade visual externa dos ovos. Estes resultados, por sua vez, são diferentes dos encontrados em trabalhos como os de Appleby (1998) e Abrahammson \& Tauson (1995) citados por Guesdon \& Faure (2004), em que um dos grandes inconvenientes do sistema em cama é a qualidade dos ovos.

Para a condição de ambiente de estresse, a situação é a mesma, ou seja, embora os valores de porcentagem de ovos tenham aumentado, o sistema em cama ainda se mostra superior quanto ao numero de ovos limpos. Uma explicação para esta elevação nos números de ovos sujos no sistema de gaiola e ambiente de estresse é que, com o aumento do estresse provocado pelos altos valores de temperatura e UR, as aves passaram a consumir mais água e isso, por sua vez, aumentou a quantidade de fezes o que provavelmente possa ter contribuído para este aumento.

Segundo Lima (1991), é muito importante produzir ovos limpos, pois os sujos e manchados são classificados como de qualidade inferior, podendo na maioria das vezes não chegar até o consumidor final.

É possível notar ainda que ocorreu um grande aumento na porcentagem de ovos quebrados, comparando-se a condição de conforto e estresse térmico. Este aumento é provavelmente resultante da alteração dos níveis de cálcio disponíveis no organismo da ave para a formação da casca, provocado pelo processo de alcalose respiratória que se inicia quando a ave se encontra sob condições de estresse térmico.

Por meio da ovoscopia foi possível ter uma idéia da qualidade interna dos ovos, observando principalmente pontos de sangue na gema, e também da qualidade externa destes, observando os ovos que apresentavam trincas ou rachaduras na casca.

A Tabela 17 abaixo mostra o número de ovos trincados e com pontos de sangue na gema, avaliados pelo ovoscópio. Por esta tabela é possível constatar um maior numero de ovos com pontos de sangue na gema e com a presença de trincas na casca para a condição de estresse térmico e sistema de criação em gaiola, principalmente para a linhagem Hy-line Brown. O que esta de acordo com Jacob et al. 
(2000), que observaram em seu trabalho que as linhagens marrons em geral apresentavam um maior número de ovos com pontos de sangue.

Ainda segundo Jacob et al. (2000), pontos de sangue são resultantes de hemorragias internas em pequenos vasos sanguíneos situados ou no ovário ou no oviduto das aves, sendo que pontos de sangue na gema são geralmente ocasionados por hemorragias no ovário.

Tabela 17. Número de ovos com ponto de sangue e trincados avaliados pela ovoscopia

\begin{tabular}{ccccc} 
& & \multicolumn{2}{c}{$\mathrm{N}^{\circ}$ ovos } \\
\hline Condição & Linhagem & Sistema & Pontos de sangue & Trincas \\
\hline \multirow{4}{*}{ Conforto } & \multirow{2}{*}{ W36 } & Cama & 0 & 0 \\
& \multirow{4}{*}{ Brown } & Gaiola & 0 & 1 \\
& & Cama & 0 & 0 \\
& & Gaiola & 0 & 1 \\
\multirow{4}{*}{ Estresse } & \multirow{2}{*}{ W36 } & Cama & 1 & 0 \\
& \multirow{2}{*}{ Brown } & Gaiola & 1 & 3 \\
& & Cama & 1 & 0 \\
& & Gaiola & 2 & 4 \\
\hline
\end{tabular}

O número de ovos com pontos de sangue foi muito pequeno, o que esta de acordo com o descrito por Jacob et al. (2000), que pôde constatar que menos de $1 \%$ de toda a produção de ovos continha pontos de sangue.

Quanto ao aumento do número de ovos trincados para a condição de estresse térmico, principalmente para o sistema de criação em gaiolas, a explicação seria que, conforme já demonstrado pela análise dos paramentos de qualidade porcentagem de casca e espessura da casca, o estresse térmico leva a uma alteração dos níveis de cálcio disponíveis no organismo das aves para a formação da casca, o que resulta em ovos com casca mais finas e frágeis e portanto mais susceptíveis as trincas.

\subsubsection{Contaminação dos ovos}

A contaminação dos ovos começa na granja, principalmente por causa das cascas infectadas por matéria fecal, que acontece no momento da postura, ou logo após, por contato com a cama, ninhos ou mesmo gaiolas contaminadas. Da casca, as bactérias penetram através dos poros e multiplicam-se no interior dos ovos, Souza et al. (2002). 
De acordo com Padron (1990), a Salmonella e outros tipos de bactérias podem penetrar pela casca e membranas dos ovos e contaminar as partes internas destes.

Quanto à análise realizada nesta pesquisa, para a verificação da ocorrência de Salmonella sp nas cascas e nas gemas dos ovos para cada linhagem, sistema de criação e condição ambiental, foi possível verificar a ausência de contaminação para ambas as partes avaliadas sob qualquer uma das condições propostas.

Como se sabe, a Salmonella, quando presente em um ambiente, pode se espalhar rapidamente via contaminação cruzada ou via sistema de ventilação, Cason et al. (1994). E em se tratando de um ambiente totalmente fechado como o da câmara climática, a situação ficaria ainda pior, e em pouco tempo todas as aves estariam contaminadas. Com isso pode-se concluir que, se para um ovo a análise de ocorrência de Salmonella foi negativa, provavelmente todos os outros também não estarão contaminados.

A análise de presença de coliformes fecais está descrita na Tabela 18 abaixo.

Tabela 18. Teste de contaminação das partes do ovo por coliformes fecais

\begin{tabular}{|c|c|c|c|c|}
\hline & & risticas Mi & robiológicas & \\
\hline Parâmetro & Local & Condição & $\begin{array}{l}\text { Parte do ovo } \\
\end{array}$ & Resultado \\
\hline \multirow{16}{*}{ coliformes fecais } & Gaiola & \multirow{2}{*}{ Conforto } & Casca & Ausência \\
\hline & W36 & & Gema & Presença \\
\hline & Gaiola & \multirow{2}{*}{ Conforto } & Casca & Ausência \\
\hline & Brown & & Gema & Ausência \\
\hline & Ninho & \multirow{2}{*}{ Conforto } & Casca & Presença \\
\hline & Brown & & Gema & Ausência \\
\hline & Ninho & \multirow{2}{*}{ Conforto } & Casca & Presença \\
\hline & W36 & & Gema & Ausência \\
\hline & Gaiola & \multirow{2}{*}{ Estresse } & Casca & Ausência \\
\hline & W36 & & Gema & Ausência \\
\hline & Gaiola & \multirow{2}{*}{ Estresse } & Casca & Ausência \\
\hline & Brown & & Gema & Ausência \\
\hline & Ninho & \multirow{2}{*}{ Estresse } & Casca & Ausência \\
\hline & Brown & & Gema & Ausência \\
\hline & Ninho & \multirow{2}{*}{ Estresse } & Casca & Presença \\
\hline & W36 & & Gema & Ausência \\
\hline
\end{tabular}

Observa-se uma maior ocorrência de presença de coliformes fecais nas cascas dos ovos postos no ninho, independentemente das condições ambientais, o que nos remete a um dos grandes pontos negativos e de questionamento sobre o quanto 0 sistema com cama e ninho é seguro sob o ponto de vista de segurança dos alimentos. 


\section{CONCLUSÕES}

De acordo com os resultados obtidos nesta pesquisa, pôde-se concluir que:

- sob o ponto de vista comportamental o sistema "cama+ninho" propiciou melhores condições de bem-estar para as duas linhagens avaliadas em comparação com o sistema em gaiolas, para as condições de conforto e estresse térmico.

- as condições ambientais avaliadas não interferiram na preferência pela postura em ninho, para as duas linhagens avaliadas.

- pela análise comportamental das aves, por meio da análise de imagens, verificou-se a ocorrência dos comportamentos naturais e de conforto no sistema "cama+ninho", o que possibilitou melhores condições de bem-estar para as aves alojadas neste sistema.

- das linhagens avaliadas, a linhagem Hy-Line W36 foi a que apresentou um melhor desempenho para o sistema "cama+ninho", em função dos parâmetros comportamentais, fisiológicos e quantiqualitativos da produção de ovos.

- os parâmetros de qualidade dos ovos foram influenciados pelo sistema de produção quando as aves foram submetidas ao sistema de criação em gaiolas. 
ANEXOS 


\section{Linhagem HY-LINE BROWN}

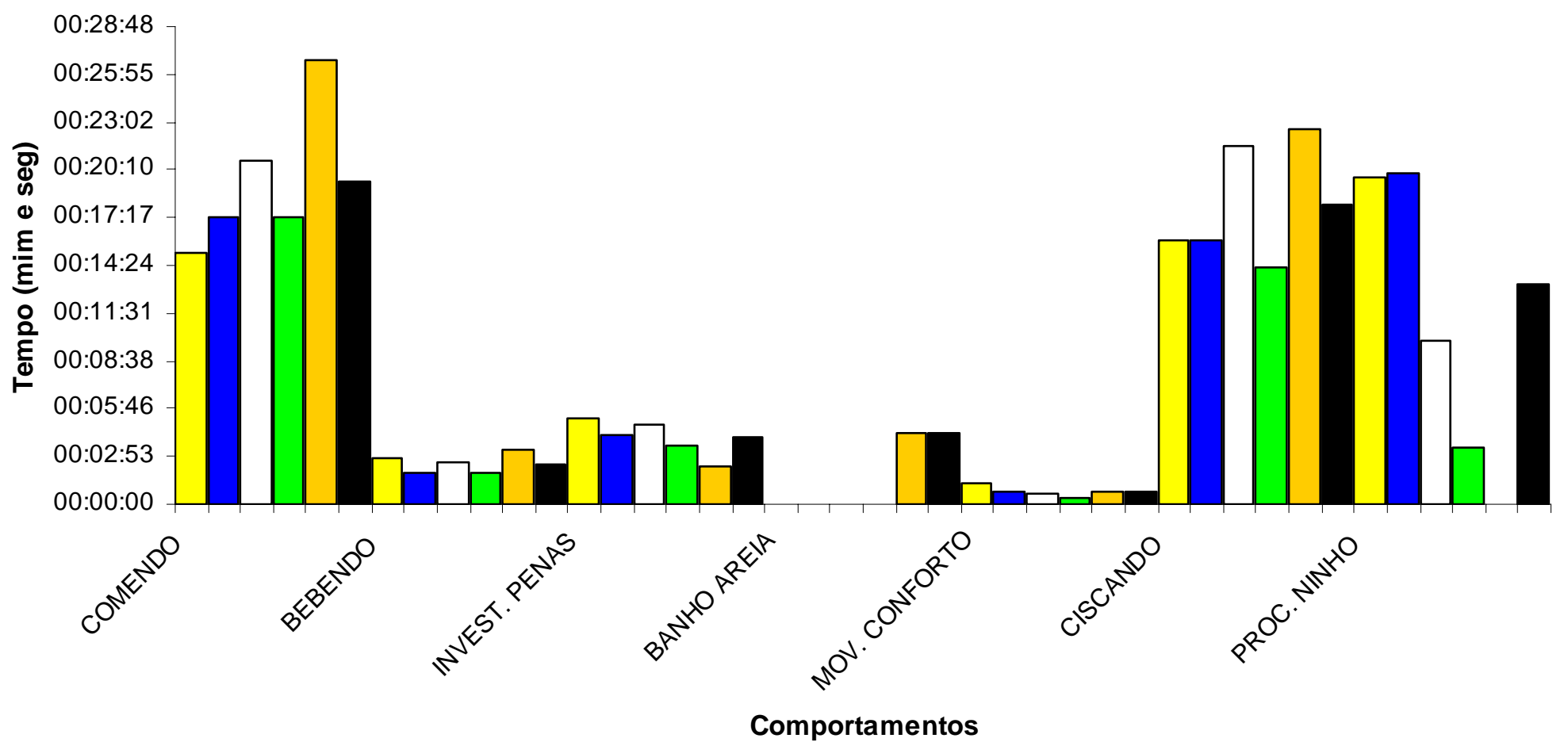

Anexo A - Duração dos comportamentos da linhagem Hy-Line Brown no período das 10:00 às 11:00 h para a condição de conforto (11/08)

Obs: As cores: amarelo, azul, branco, verde e marrom, são as corres de identificação de cada ave, e a cor preta é a média dos tempos de expressão de cada comportamento. 


\section{Linhagem HY-LINE BROWN}

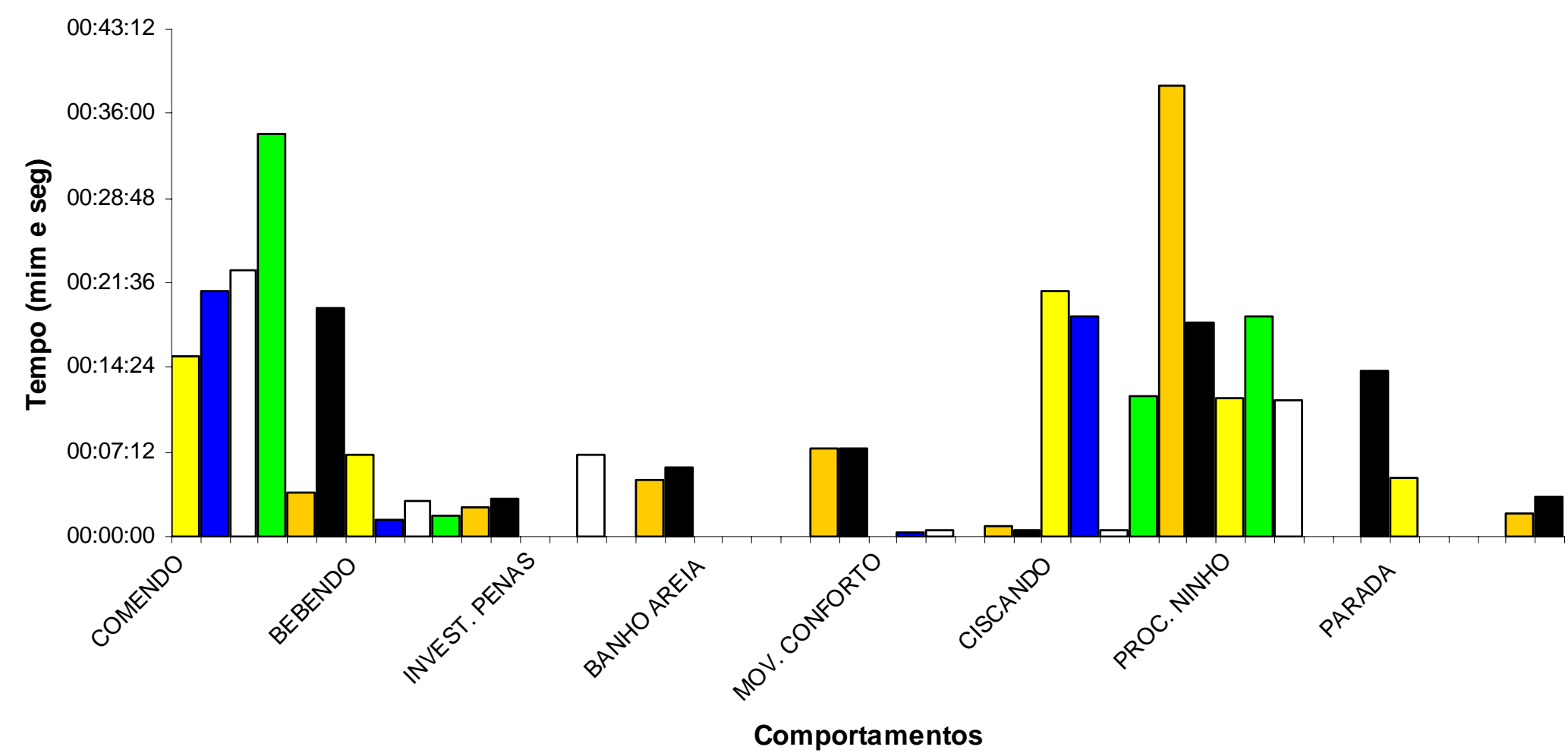

Anexo B - Duração dos comportamentos da linhagem Hy-Line Brown no período das 13:00 às 14:00 h para a condição de conforto (11/08)

Obs: As cores: amarelo, azul, branco, verde e marrom, são as corres de identificação de cada ave, e a cor preta é a média dos tempos de expressão de cada comportamento. 


\section{Linhagem HY-LINE BROWN}

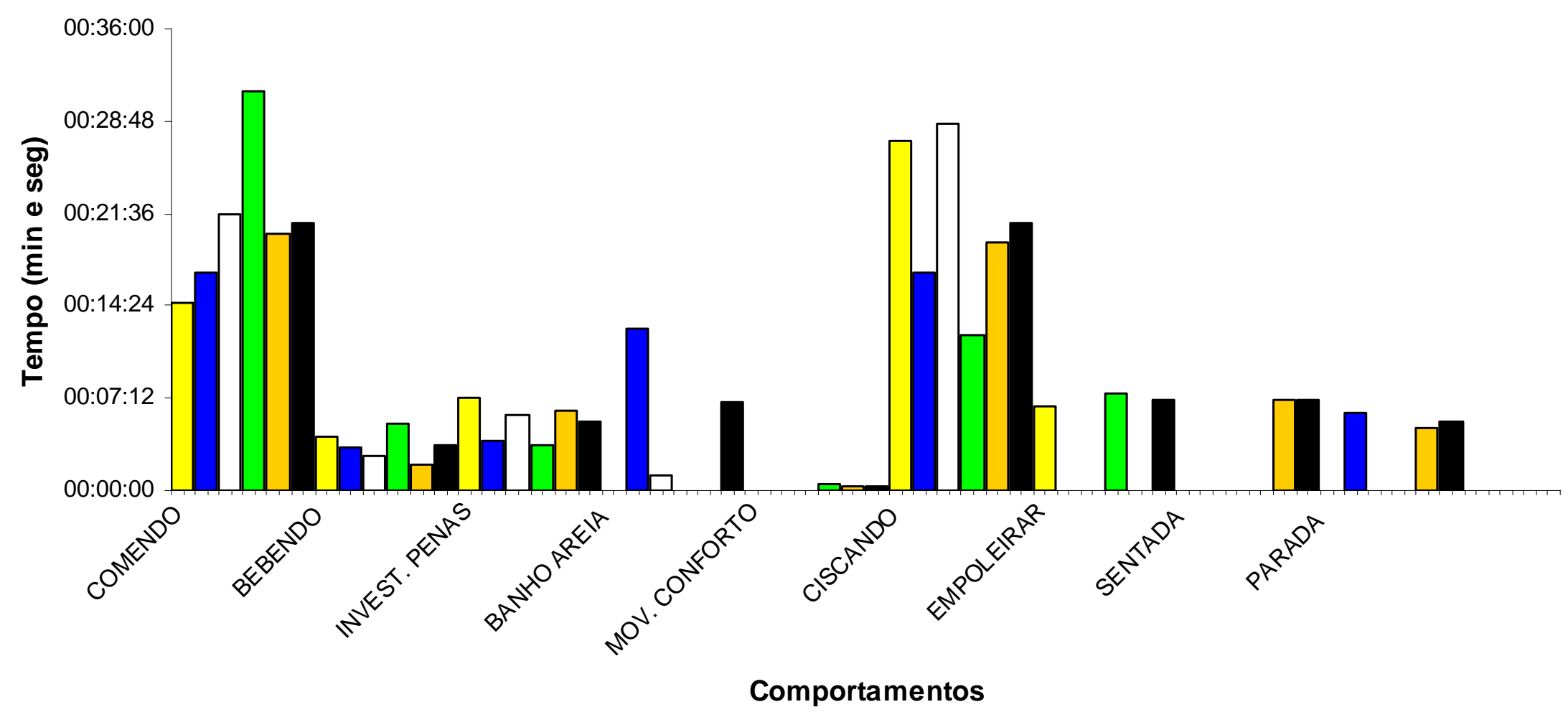

Anexo C - Duração dos comportamentos da linhagem Hy-Line Brown no período das 16:00 às 17:00 h para a condição de conforto (11/08)

Obs: As cores: amarelo, azul, branco, verde e marrom, são as corres de identificação de cada ave, e a cor preta é a média dos tempos de expressão de cada comportamento. 


\section{Linhagem HY-LINE W36}

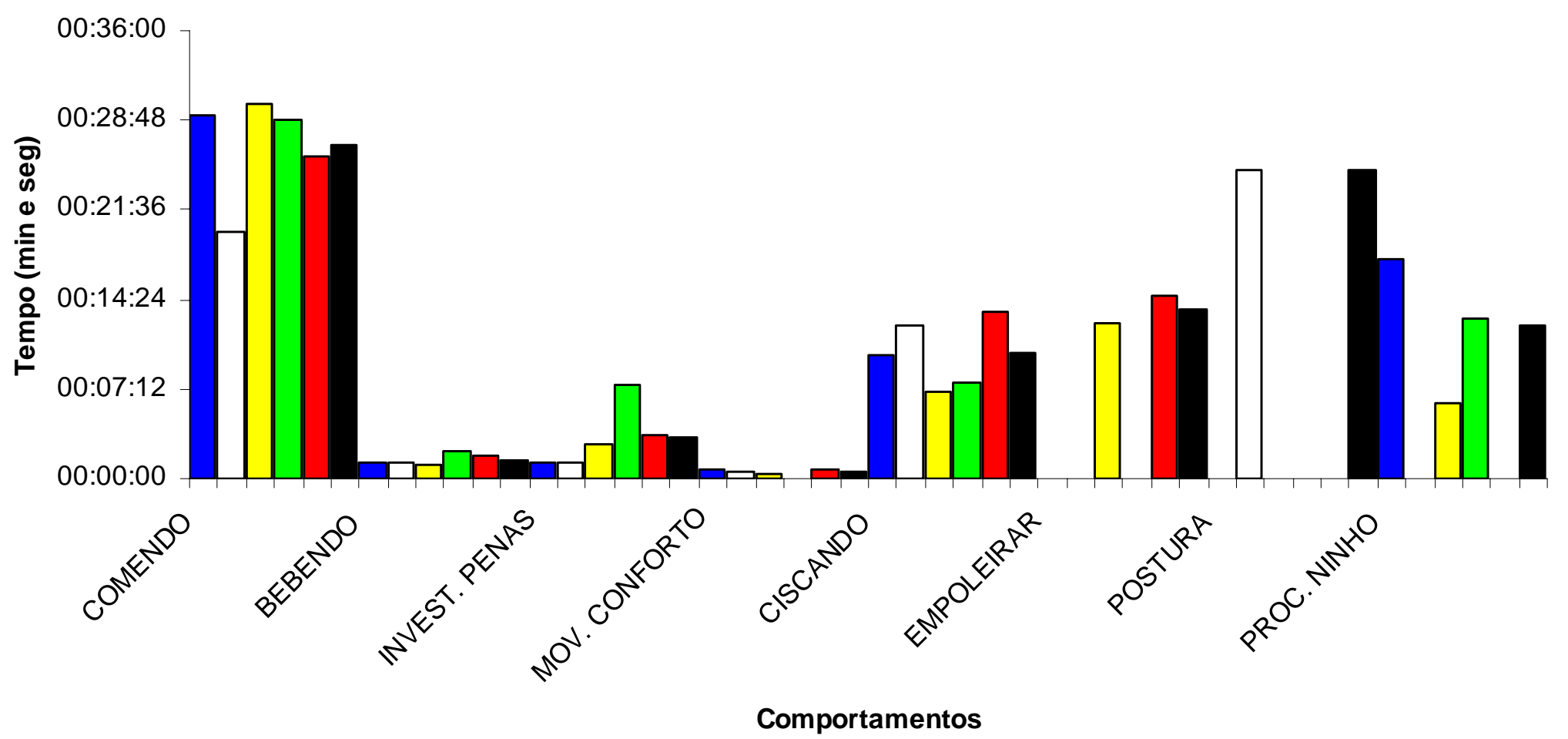

Anexo D - Duração dos comportamentos da linhagem Hy-Line W36 no período das 10:00 às 11:00 h para a condição de conforto (11/08)

Obs: As cores: azul, branco, amarelo, verde e vermelho, são as corres de identificação de cada ave, e a cor preta é a média dos tempos de expressão de cada comportamento. 


\section{Linhagem HY-LINE W36}

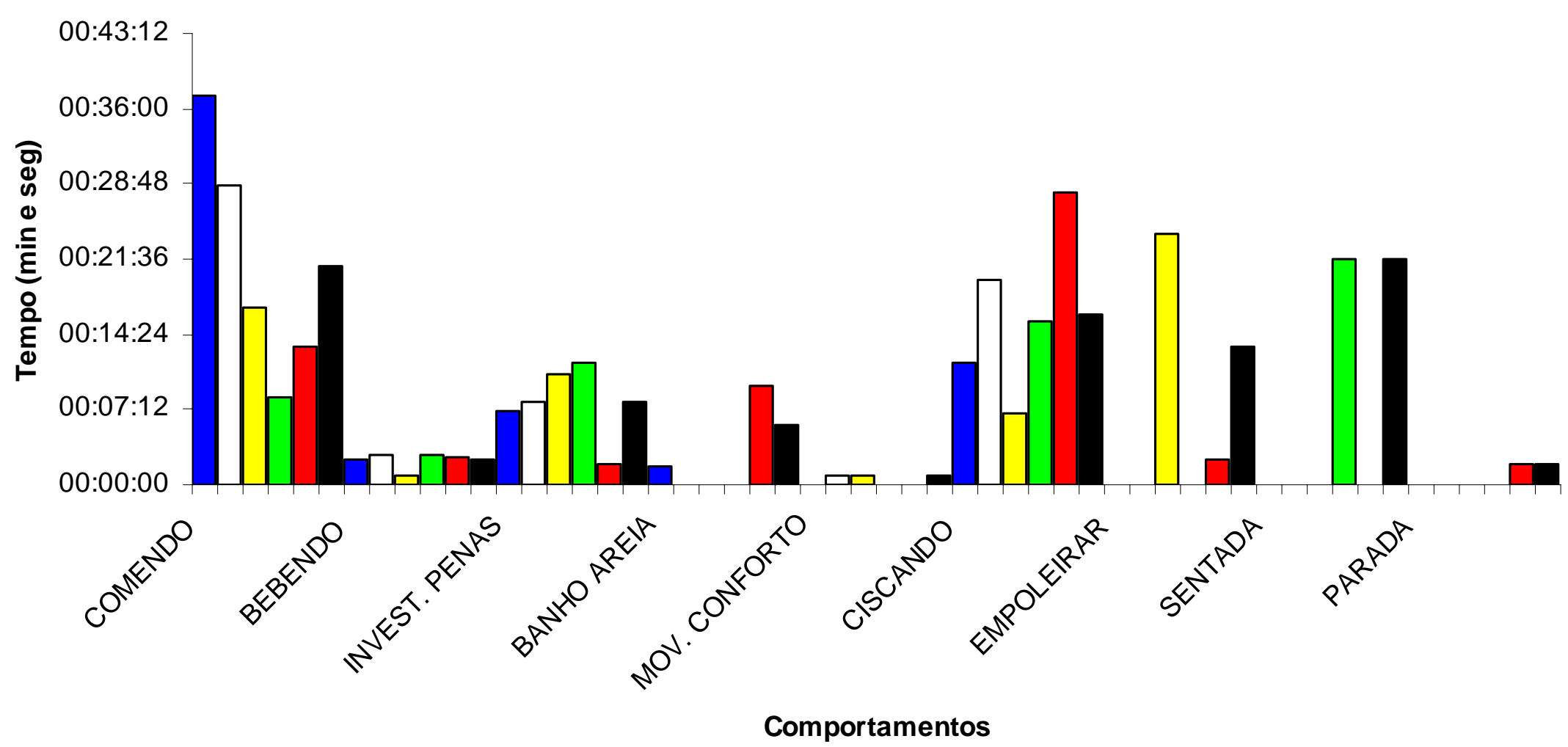

Anexo E - Duração dos comportamentos da linhagem Hy-Line W36 no período das 13:00 às 14:00 h para a condição de conforto (11/08)

Obs: As cores: azul, branco, amarelo, verde e vermelho, são as corres de identificação de cada ave, e a cor preta é a média dos tempos de expressão de cada comportamento. 


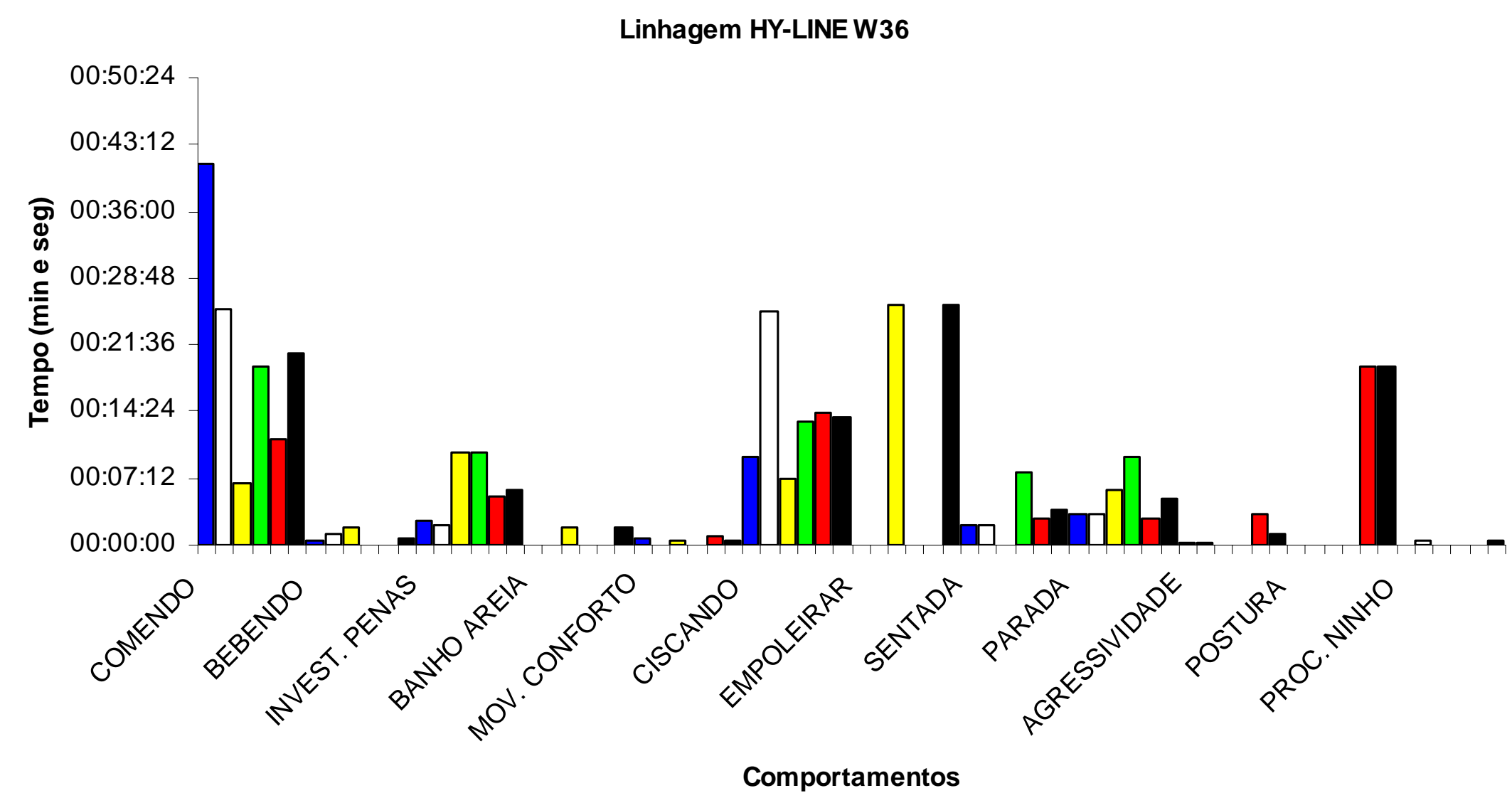

Anexo F - Duração dos comportamentos da linhagem Hy-Line W36 no período das 16:00 às 17:00 h para a condição de conforto (11/08)

Obs: As cores: azul, branco, amarelo, verde e vermelho, são as corres de identificação de cada ave, e a cor preta é a média dos tempos de expressão de cada comportamento. 


\section{Linhagem HY-LINE BROWN}

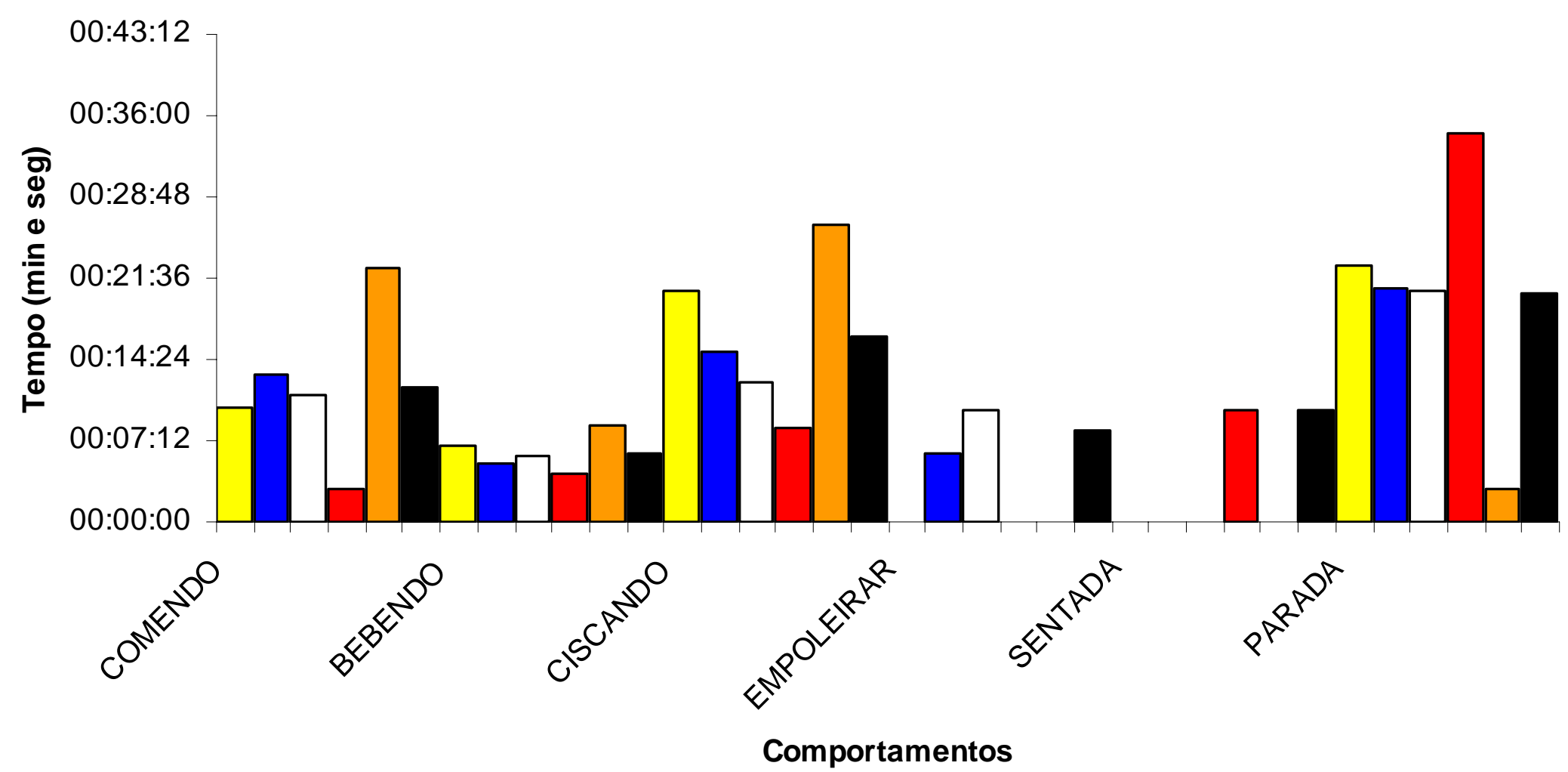

Anexo G - Duração dos comportamentos da linhagem Hy-Line Brown no período das 10:00 às 11:00 h para a condição de estresse (06/09)

Obs: As cores: amarelo, azul, branco, vermelho e marrom, são as corres de identificação de cada ave, e a cor preta é a média dos tempos de expressão de cada comportamento. 


\section{Linhagem HY-LINE BROWN}

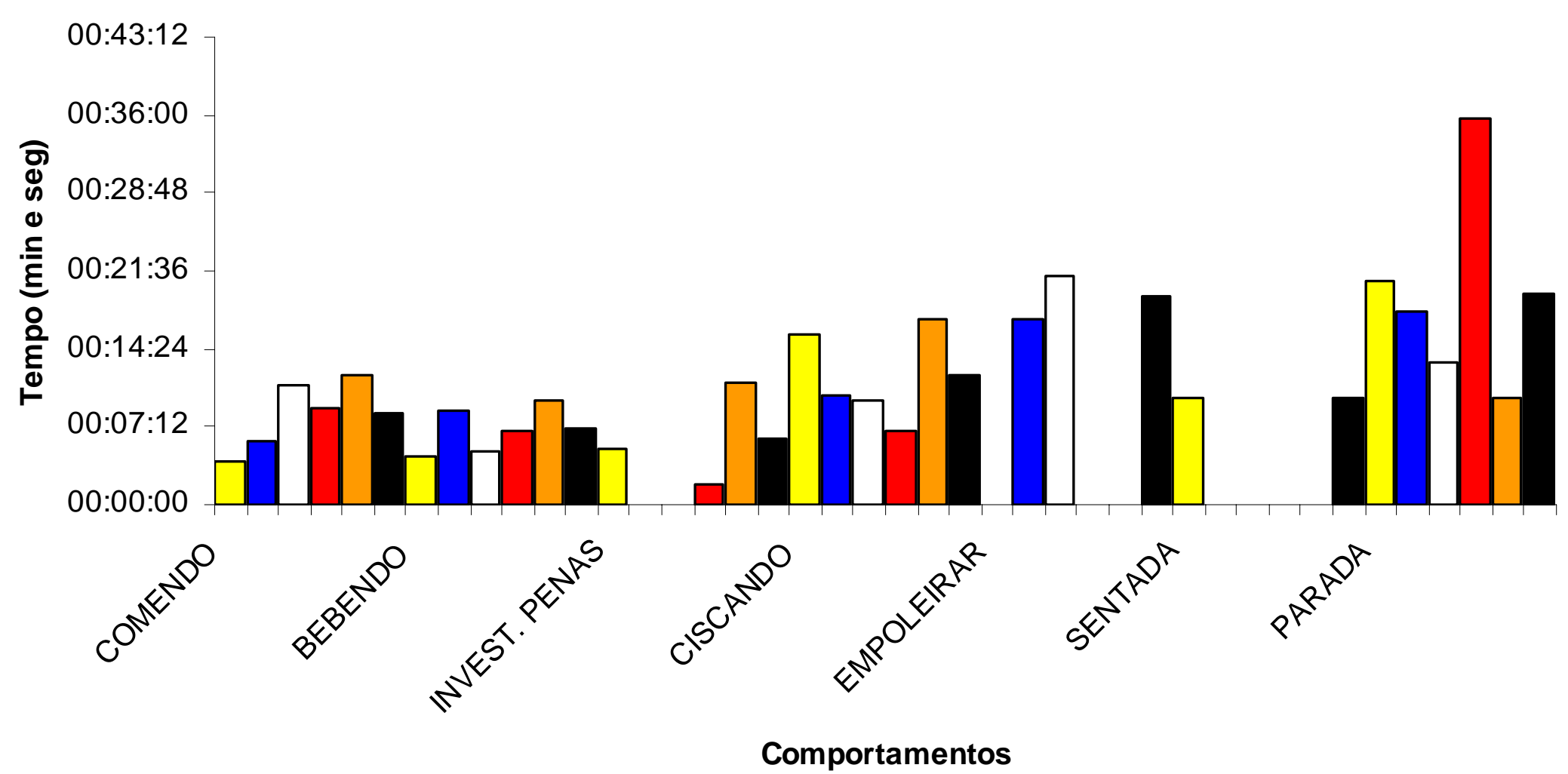

Anexo H - Duração dos comportamentos da linhagem Hy-Line Brown no período das 13:00 às 14:00 h para a condição de estresse (06/09)

Obs: As cores: amarelo, azul, branco, vermelho e marrom, são as corres de identificação de cada ave, e a cor preta é a média dos tempos de expressão de cada comportamento. 


\section{Linhagem HY-LINE BROWN}

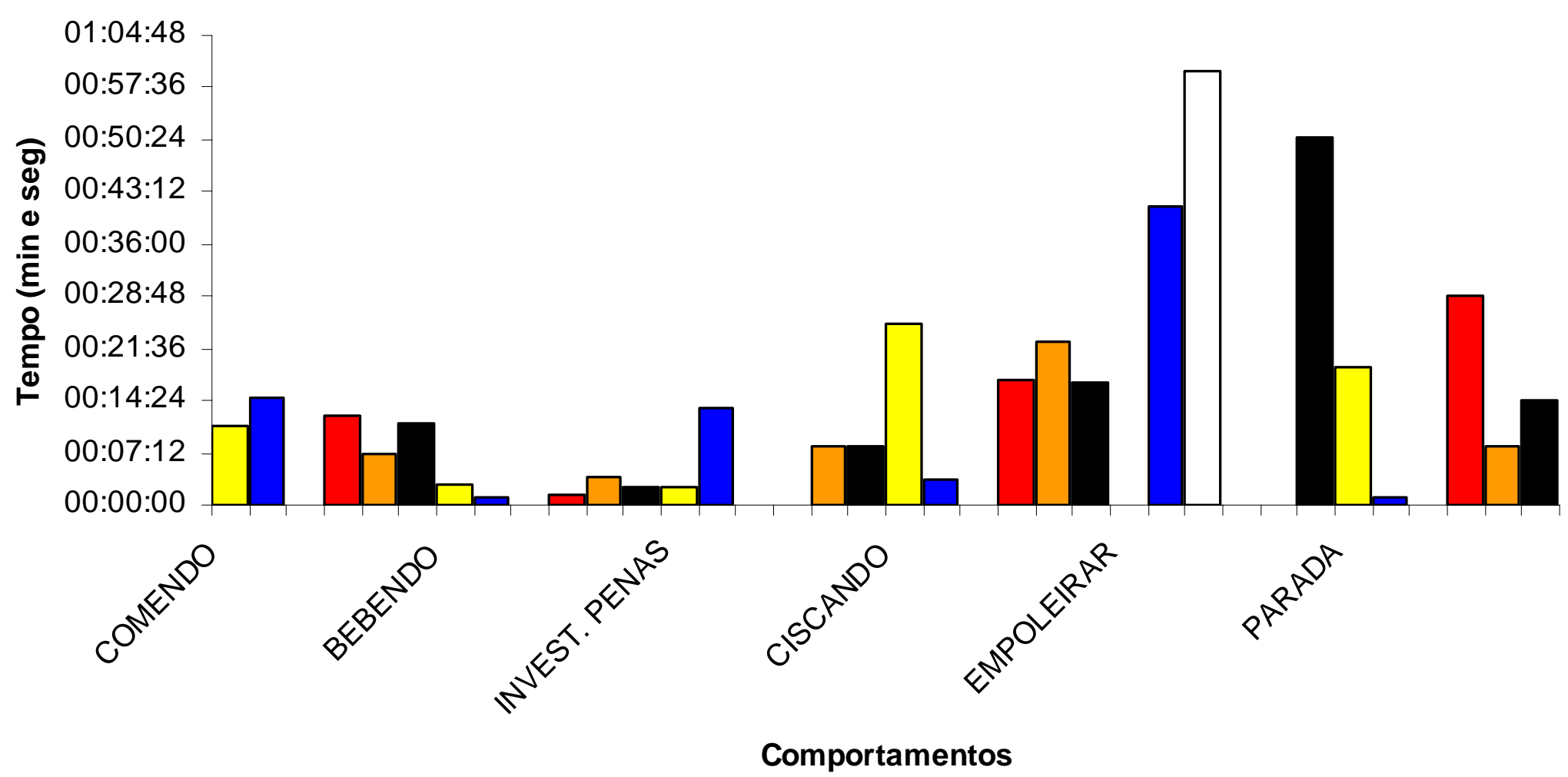

Anexo I - Duração dos comportamentos da linhagem Hy-Line Brown no período das 16:00 às 17:00 h para a condição de estresse (06/09)

Obs: As cores: amarelo, azul, branco, vermelho e marrom, são as corres de identificação de cada ave, e a cor preta é a média dos tempos de expressão de cada comportamento. 


\section{Linhagem HY-LINE W36}

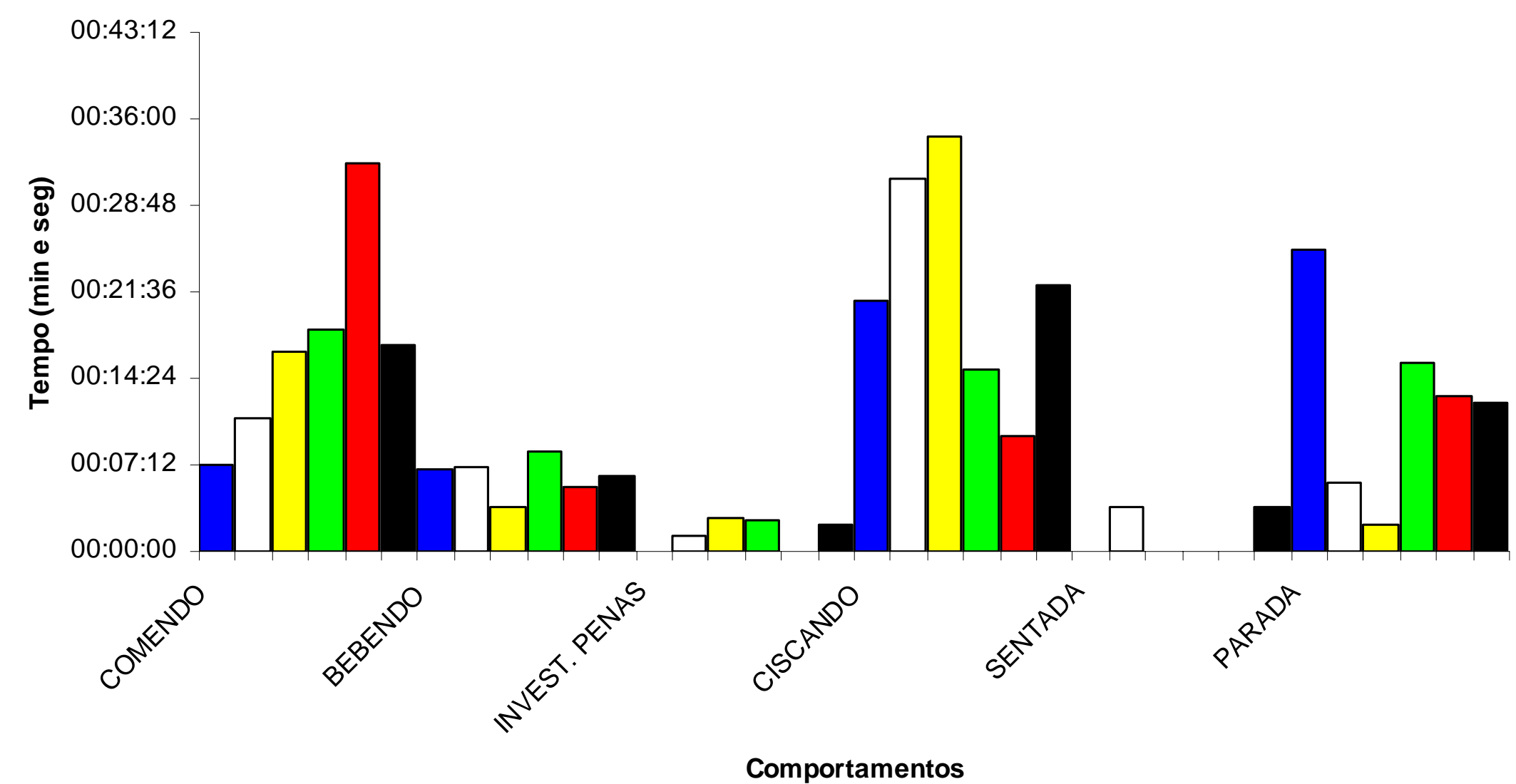

Anexo J - Duração dos comportamentos da linhagem Hy-Line W36 no período das 10:00 às 11:00 h para a condição de estresse (06/09)

Obs: As cores: azul, branco, amarelo, verde e vermelho, são as corres de identificação de cada ave, e a cor preta é a média dos tempos de expressão de cada comportamento. 


\section{Linhagem HY-LINE W36}

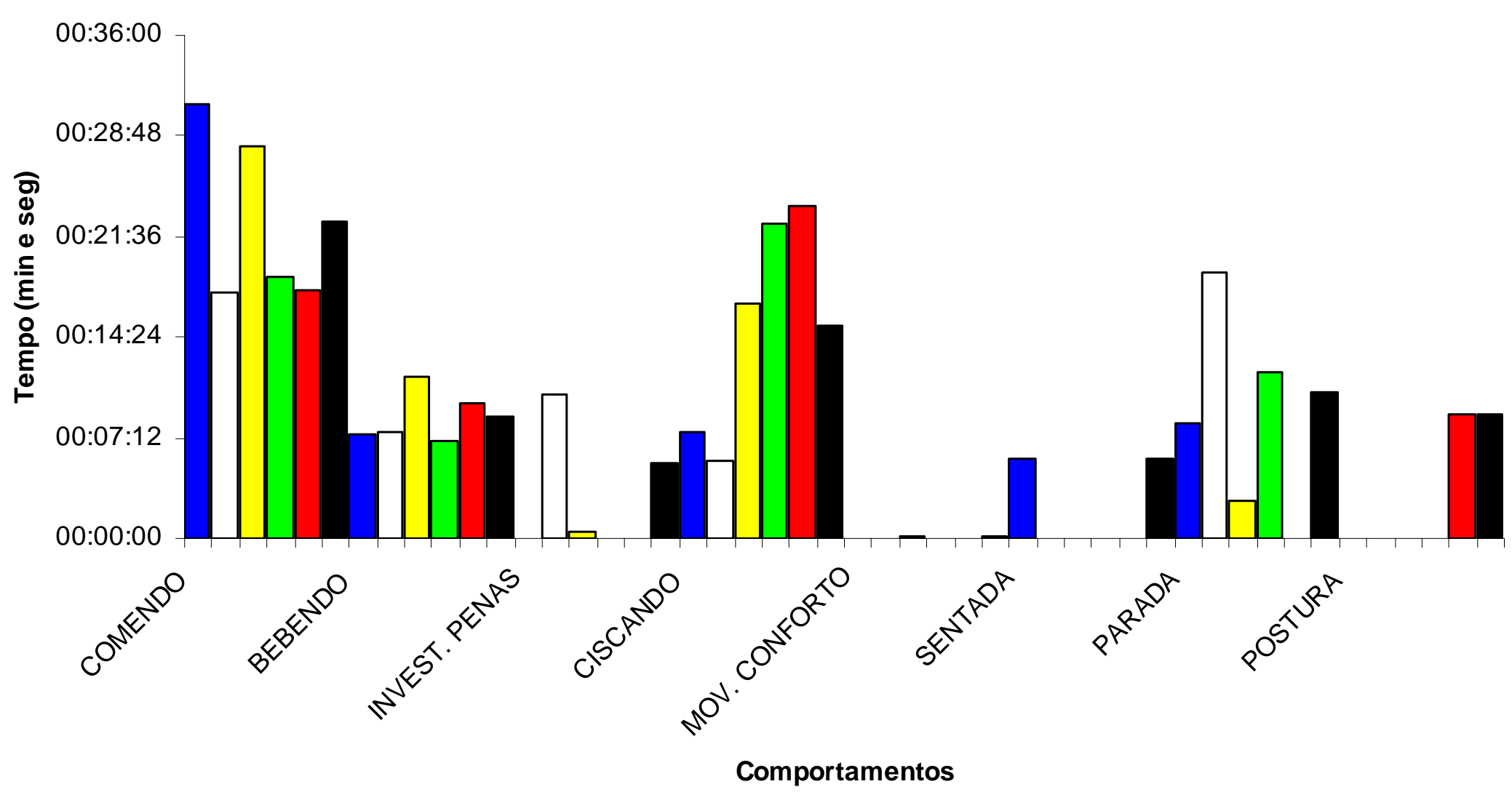

Anexo K - Duração dos comportamentos da linhagem Hy-Line W36 no período das 13:00 às 14:00 h para a condição de estresse (06/09)

Obs: As cores: azul, branco, amarelo, verde e vermelho, são as corres de identificação de cada ave, e a cor preta é a média dos tempos de expressão de cada comportamento. 


\section{Linhagem HY-LINE W36}

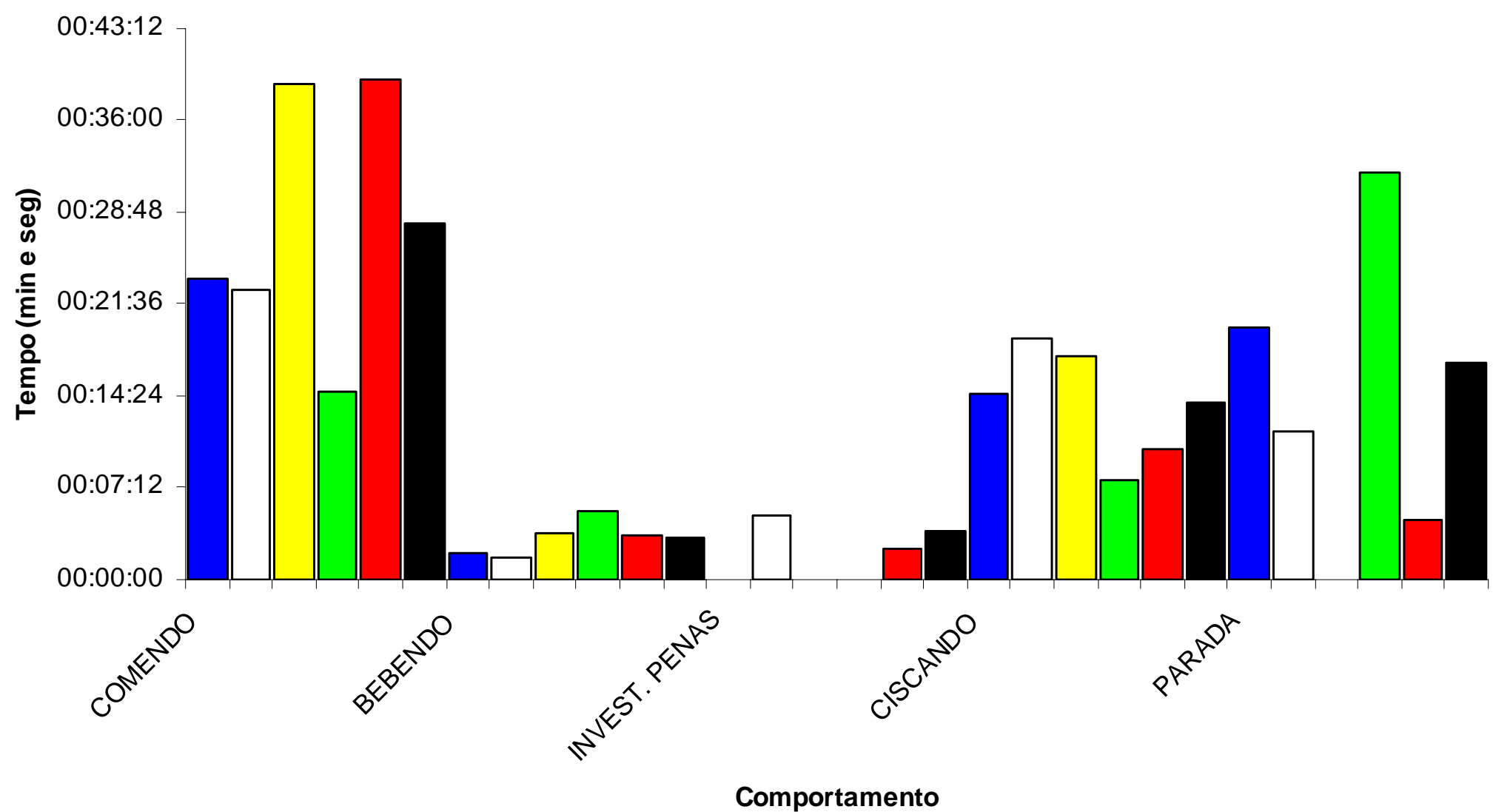

Anexo L - Duração dos comportamentos da linhagem Hy-Line W36 no período das 16:00 às 17:00 h para a condição de estresse (06/09)

Obs: As cores: azul, branco, amarelo, verde e vermelho, são as corres de identificação de cada ave, e a cor preta é a média dos tempos de expressão de cada comportamento. 


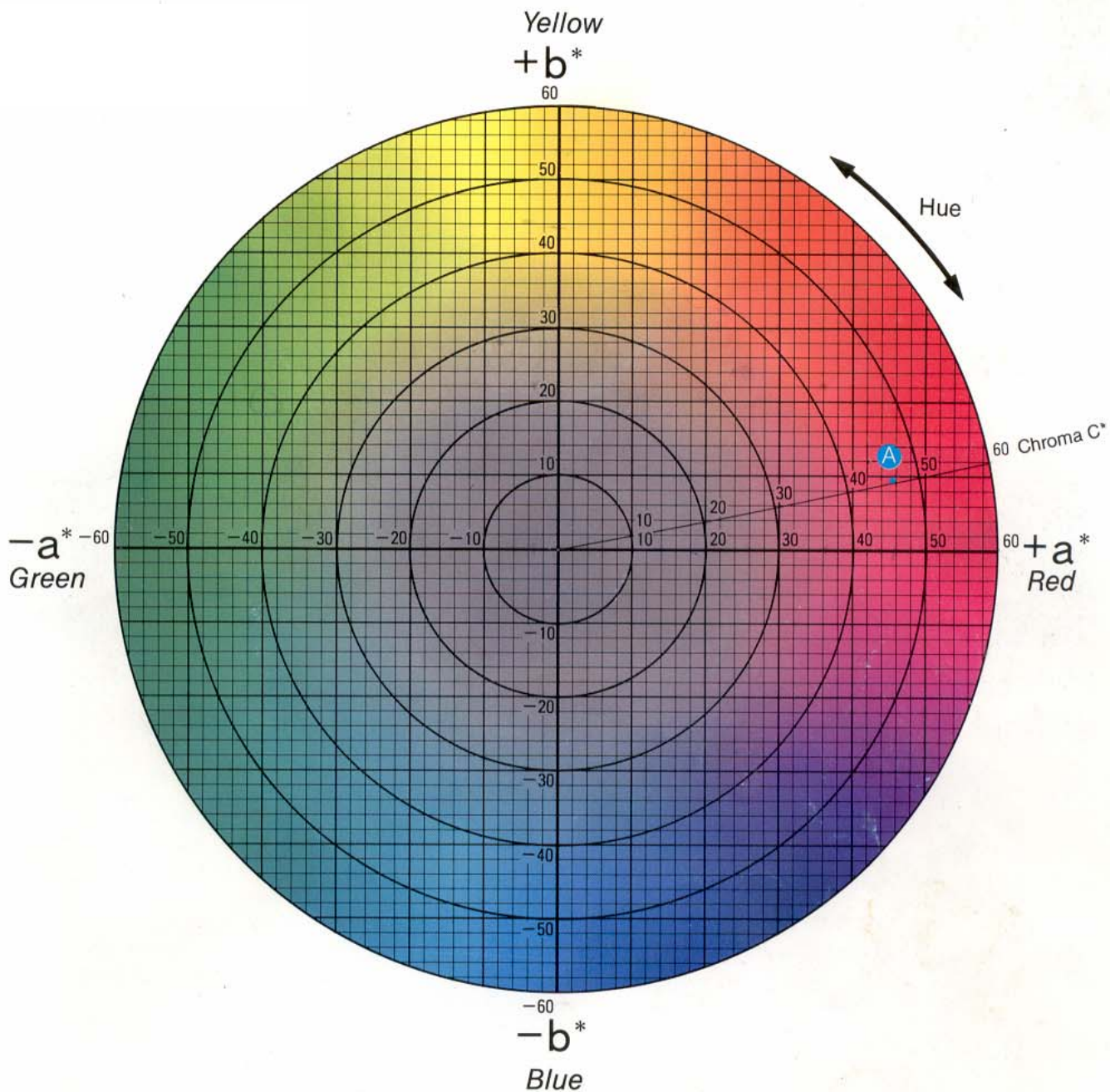

Fig. 8: Modifiers related to color tone

This figure shows the above color chart rotated $90^{\circ}$ with Value $L^{\star}$ extended above the line drawn from the center through Chroma $C^{*}$

Blue

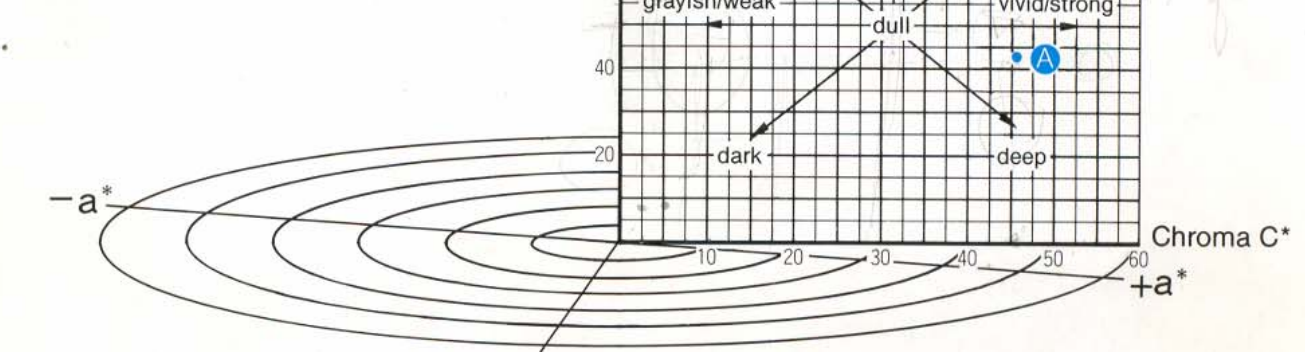

Anexo $\mathrm{M}$ - Ábaco de cores - Valores de $\mathbf{a}, \mathbf{b}$ e $\mathbf{L}$ 


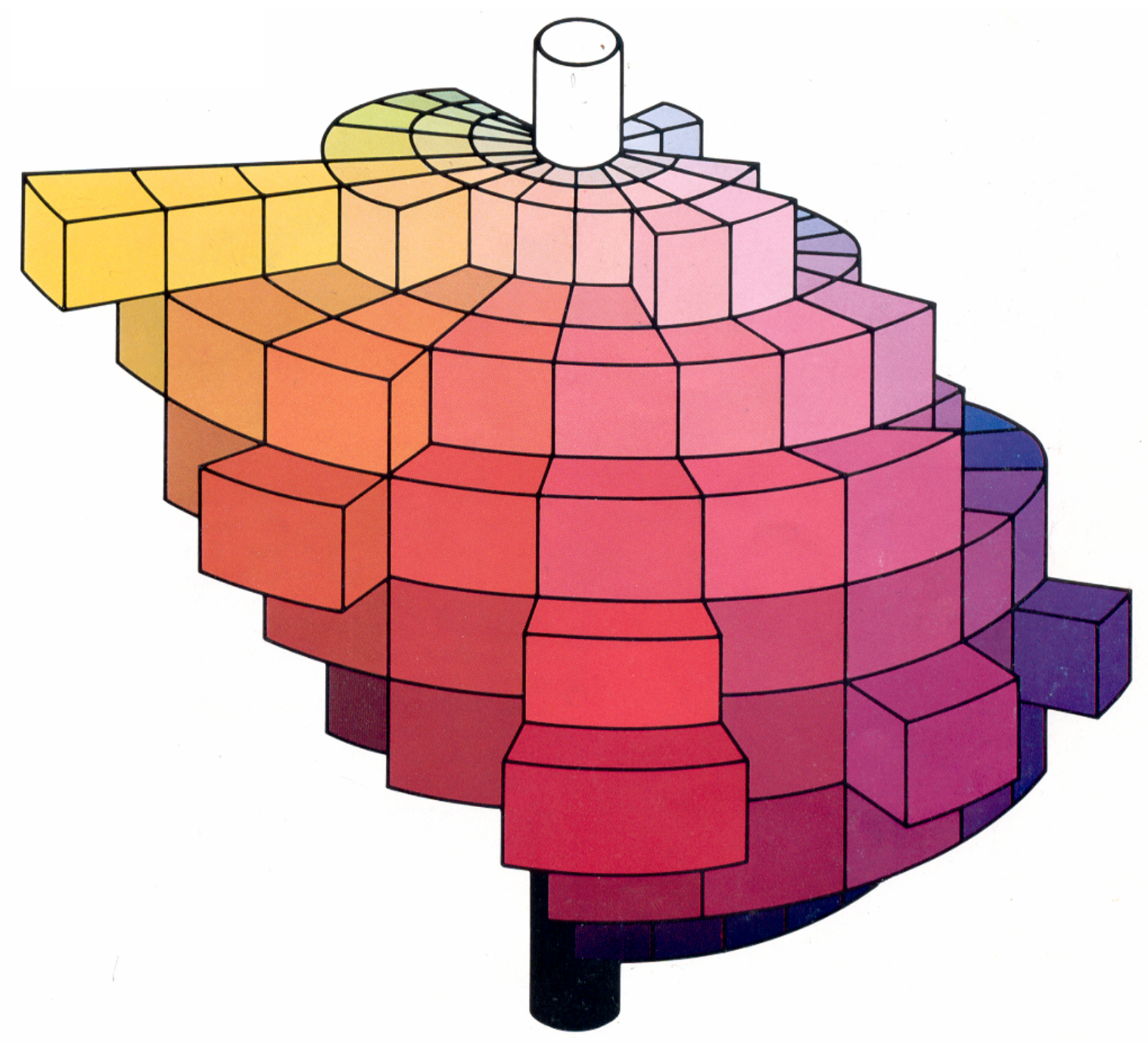

Anexo N - Sólido de cores 


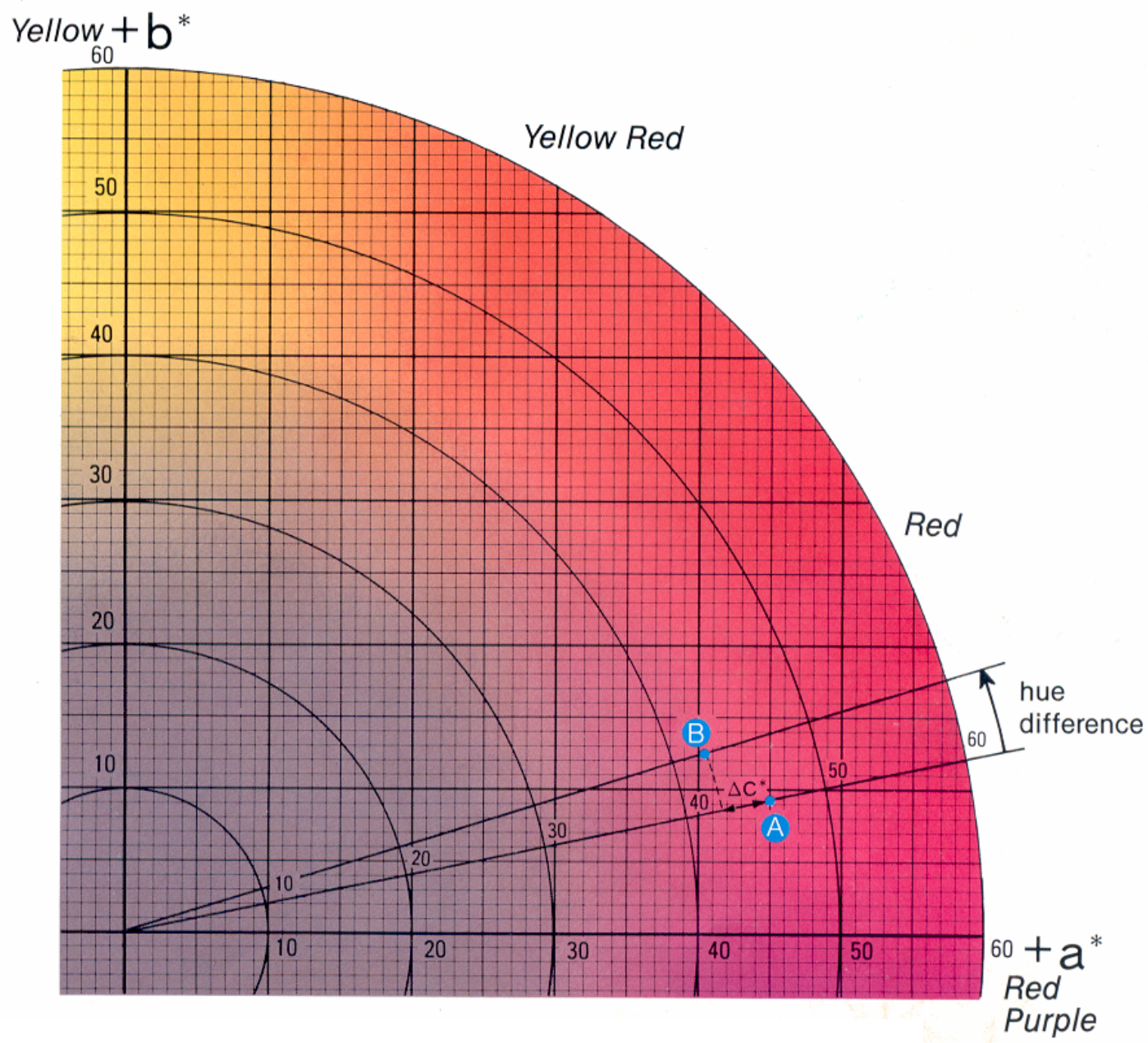

Anexo O - Ábaco de cores 


\section{REFERÊNCIAS BIBLIOGRÁFICAS}

ABRAHAMSSON, P. Furnished cages and aviaries for laying hens: Effects on production, health and use of facilities. Swedish University of Agricultural Sciences, Upsala. Department of Animal Nutrition and Management, 1996, (Report 234).

ABREU, V.M.N.; SILVA, M.A.; TORRES, R.A.; SOARES, P.R.; PANIAGO, M.T.; ABREU, P.G. Características produtivas de linhagens de corte. Revista da Sociedade Brasileira de Zootecnia, v. 25, n. 1, p. 83-91, 1996.

ALLEONI, A.C.C.; ANTUNES, A.J. Unidade haugh como medida da qualidade de ovos de ave armazenados sob refrigeração. Revista Scientia Agrícola, v. 58, n. 4, p. 681-685, 2001.

ALMEIDA, M.A.C. Fatores que afetam a umidade da cama. Avicultura Industrial. n. 76, p. 16,18, 1986.

ANDRADE, A.N.; ROGLER, J.C.; FEATHERSTON, W.R. Influence of constant elevated temperature and diet on egg production and shell quality. Poultry Science, v. 55, p. $685-693,1976$.

ANUÁRIO DA AVICULTURA INDUSTRIAL 2004. Revista Avicultura Industrial, v. 95, n. 1118, p. 43-47, 2004.

ANUALPEC 2004. Anuário da pecuária brasileira. São Paulo, SP. FNP - Consultoria \& Agroinformativos, 2004. p. 233-266. 
APPLEBY, M.C. Modification of Laying Hen Cages to Improve Behaviour. Poultry Science, v. 77, p. 1828-1832, 1998.

APPLEBY, M.C. The Eurpean Union Ban on Conventional Cages for Laying Hens: History and Prospects. Journal of Applied Animal Welfare Science, n. 6, p. 103121, 2003.

APPLEBY, M.C.; SMITH, S.F.; HUGHES, B.O. Nesting, Dustbathing and Perching by Laying Hens in Cages: Effects of Design on Behaviour and Welfare. British Poultry Science, n. 34, p. 835-847, 1993.

ARAYA, H. H.; MURILLO, M. R.; VARGAS, E. G.; DELGADO, J. M. Composición y empleo del achiote (Bixa orellana L.) en raciones para gallinas ponedoras, para la pigmentacion de la yema del huevo. Agronomia Costarricense, v.1, n. 2, p. 143-150, 1977.

ARTMANN, R. Computers and electronics in agriculture. p. 5-26, 1999.

AVISITE. União européia pode antecipar proibição de gaiolas para aves poedeiras. http://avisite.com.br/. (28 ago. 2002).

BATISTA, C. L. L. C. Produção e avaliação da estabilidade de corante hidrossolúvel de urucum. Viçosa: UFV, 1994. 71p.

BECKER, B.G. Comportamento das aves e sua aplicação prática. In: CONFERÊNCIA APINCO DE CIÊNCIA E TECNOLOGIA AVÍCOLAS, Anais, 2002.

BEKER, A.; TEETER, R.G. Drinking water temperature and potassium supplementation effects on broiler body temperature and performance during heat stress. Journal of Applied Poultry Research, v. 3, n. 1, p. 87-98, 1994.

BELL, D. Raising replacement pullets in cages. Univ. California. Mim. 13p. 
BENNION, N.L.; WARREN, D.C. Temperature and its effect on egg size in the domestic fowl. Poultry Science, v. 12, p. 69-82, 1933.

BERRANG, M.E.; FRANK, J.F.; BUHR, R.J.; BAILEY, J.S.; COX, N.A.; MAULDIN, J. Eggshell characteristics and penetration by salmonella trhough the productive life of a broiler breeder flock. Poultry Science, v. 77, p. 1446-1450, 1998.

BIBLE, B.B. SINGHA, S. Canopy position influences cielab coordinates of peach color. Hortscience, v.28, n.10, p.992-993, 1993.

BORBAS, A.; MINVELLE, F. Résponse à la chaleur de poules pondeuses issues de lignées sélectionnées pour une faible $(R-)$ ou forte $(R+)$ consomation alimentaire resíduelle. Genetics, Selection, Evolution, v. 29, n. 3, p. 279-290, 1997.

CARMON, L.G.; HUSTON, T.M. The influence of environmental temperature upon egg components of domestic fowl. Poultry Science, v. 44, p. 1237-1240, 1965.

CASON, J.A.; COX, N.A.; BALLEY, J.S. Transmissions of Salmonella Typhimuriuon during hatching of broiler chicks. Avian Desease. n. 38, p. 583-588, 1994.

CIOCCA, M.L.; CARDOSO, S.; FRANZOSI, R. Criação de aves em sistemas semiextensivos. Porto Alegre: Pallotti, 1995. 112p.

CLOUTIER, S.; NEWBERRY, R.C.; FORSTER, C.T.; GIRSBERGER, K.M. Does pecking at inanimate stimuli predict cannibalistic behavior in domestic fowl? Applied Animal Behavior Science, p - 119,133. 2000.

CODE OF RECOMENDATIONS FOR THE WELAFARE OF LIVESTOCK - LAYING HENS. England :DEFRA - Department for Environmente, Food \& Rural Affairs, 2003. 32p. 
COMISSÃO EUROPÉIA. Directiva do Conselho 1999/74/EC de 19 de Julho de 1999, que estabelece as normas mínimas relativas à proteção das aves poedeiras. Jornal Oficial das Comunidades Européias. L203, 03/08/1999.

COOPER, J.J.; APPLEBY, M.C. Individual variation in the demand for a nest-box and the incidence of floor eggs. Applied Animal Behavior Science, n. 44, p. 257-281, 1996.

COOPER, J.J.; APPLEBY, M.C. Demand for nest boxes in laying hens. Behavioural Processes, n. 36, p. 171,182, 1996.

CRAIG, J.V. Measuring social behavior in poultry. Poultry Science, v. 71, p. 650-657, 1992.

CURTO, F.P.F. et. al. Desenvolvimento de um sistema de identificação eletrônica para auxilio no gerenciamento de informações na área de produção animal - Programa de Pós-Graduação. Campinas:Instituto PUCCAMP de Informática, 1998.

DAWKINS, M.S. Time budgets in red jungle fowl as a baseline for the assessment of welfare of domestic fowl. Applied Animal Behavior Science, v. 24, p. 77-80, 1989.

DE ANDRADE, A.N.; ROGLER, J.C.; FEATHERSTON, W.R. Influence of elevated temperature and diet on egg production and shell quality. Poultry Science, v. 55, p. 685-693, 1976.

DUNCAN, I.J.H.; KITE, V.G. Some investigations into motivation in domestic fowl. Applied Animal Behaviour Science, v. 37, p. 215-231, 1987.

DUNCAN, I.J.H.; SAVORY, C.J.; WOOD-GUSH, D.G.M. Observations on the reproductive behaviour of domestic fowl in the wild. Applied Animal Ethology, n. 4, p. 29-42, 1978. 
DUNCAN, I.J.H.; WIDOWSKI, T.M.; MALLEAU, A.E.; LINDBERG, A.C.; PETHERICK, J.C. External factors and causation of dustbathing in domestic hens. Behavioural Processes, n. 43, p. 219-228, 1998.

DUSENBERY, D.B. Using a microcomputer and video camera to simultaneously track 25 animals. Computer Biological Medicine Veterinary, v. 15, n. 4, p. 169-175, 1985.

EGG-GRADING MANUAL, United States Department of Agriculture - USDA, Agricultural Handbook number 75. 2000. 56p.

ELSON, H.A. Management factors affecting shell quality. Agriculture, v. 75, n. 1, p. 22-26, 1968.

ENGLERT, S. I. Avicultura. Porto Alegre: Ed. Agropecuária, 1987. 288 p.

FABRELLO, R. Temperatura, umidade e pureza do ar, importantes fatores. A Granja. Fevereiro. 1979.

FIALHO, B.F. Modernização no controle da produção de suínos - Zootecnia de Precisão. In: SILVA, I.J.O. Ambiência e qualidade na produção industrial de suínos. Piracicaba, SP, 1999. p. 61-80.

FLETCHER, D.L.; BRITTON, W.M.; PESTI, G.M; RAHN, A.P. The relationship of layer flock age and egg component yields and solids content. Poultry Science, v. 62, p. 1800-1805, 1983.

FRASER, A.F. The term "stress" in a veterinary context. British veterinary journal, v. 131 , p. $653-662,1975$.

FRASER, A.F.; BROOM, D.M. Farm animal behavior and welfare. London: Bailliere Tindall, 1990. 437p. 
FRASER, D. Animal ethics and animal welfare science: Bridging the two cultures. Applied Animal Behavior Science, v. 65, p. 71-89, 1999.

FREEMAN, B.M. The domestic fowl in biomedical research: Physiological effects of the environment. World's Poultry Science Journal, v. 44, p. 41-60, 1988.

FURLAN, R.A. Avaliação da nebulização e abertura de cortinas na redução da temperatura do ar em ambiente protegido. Piracicaba, 2001. 146 p. Tese (Doutorado) - Escola Superior de Agricultura "Luiz de Queiroz", Universidade de São Paulo.

GUESDON, V.; FAURE, J.M. Laying performance and egg quality in hens kept in standart or furnished cages. Animal Research, n. 53, p. 45-57, 2004.

GUIA DE MANEJO 2002 - 2004 - Hy-Line Variety Brown. Hy-Line do Brasil Ltda. 18p. http://www.hylinedobrasil.com.br. (01 jul. 04).

GUIA DE MANEJO 2003 - 2005 - Hy-Line Variety W-36. Hy-Line do Brasil Ltda. 23p. http://www.hylinedobrasil.com.br. (01 jul. 04).

HAMILTON, R. M. G. Methods and factors that affect the measurement of egg shell quality. Poultry Science, v. 61, p. 2022-2039, 1982.

HARRISON, P.C.; BIELLIER, H.V. Physiological response of domestic fowl to abrupt changes of ambient air temperature. Poultry Science, p. 1034-1045, 1968.

HAUGH, R.R. The Haugh unit for measuring egg quality. United States Egg Poultry Magazine, v. 43, p. 552-555, 1993.

HOGAN, J.A.; VAN BOXEL, F. Casual factors controling dustbathing in burmese red junglefowl: some results and a model. Animal Behaviour, n. 46, p. 627-635, 1993. 
HUGHES, B.O.; DUNCAN, I.J.H. The notion of ethological "need", models of motivation and animal welfare. Animal Behaviour, n. 36, p. 1696-1707, 1988.

HUSTON, T.M.; JOINER, W.P.; CARMON, L.J. Breed differences in egg production of domestic fowl held at high environmental temperatures. Poultry Science, v. 36, p. 1247-1253, 1957.

INSTITUTO BRASILEIRO DE GEOGRAFIA E ESTATÍSTICA (IBGE). Levantamento sistemático da produção agrícola de 2004. Disponível em http://www.ibge.gov.br. (01 nov. 2004).

JACOB, J.P.; MILES, R.D.; MATHER, F.B. Egg Quality. Institute of Food and Agricultural Sciences (IFAS) - University of Florida, 2000. 11p. (Bulletin, PS24).

JENSEN, P.; TOATES, F.M. Who Needs "Behavioural Needs"? Motivatinal aspects of the needs of animals. Applied Animal Behaviour Science, n. 37, p. 161-181, 1993.

JOHNSON, N.; HOGG, D. Learning the distribution of object trajectories for evente recognition. Image and vision computing, v. 14, n. 3, p. 609-615, 1996.

JORGE, M.A.; MOUCHREK, E.; CARNEIRO, M.I.F.; MARTINS, N.R.S.; RESENDE, J.S. Coliformes em cinco tipos de cama em reutilização. Arquivo Brasileiro de Medicina Veterinária e Zootecnia, v. 49, n. 5, p. 523-530, 1997.

KEELING, L. Spacing behaviour and an ethological approach to assessing optimun space allocations for groups of laiyng hens. Applied Animal Behavior Science, v. 44, p. 171- 186, 1995.

KILGOUR, R.; DALTON, C. Livestock Behavior: A Practical Guide. London, 1984. $320 \mathrm{p}$. 
LEROY T.; CEUNEN J.; STRUELENS E.; JANSSEN A.; TUYTTENS F.; DE BAERE K.; ZOONS, J.; SONCK B.; VRANKEN E.; BERCKMANS D. Developing a quantitative computer vision method for on-line classification of poultry behaviour in furnished cages. In: ASAE Meeting, Local: Las Vegas, USA, 2003. (ASAE Paper, 034006).

LUNDBERG, A.S.; KEELING, L.J. The Impact of social factors on nesting in laying hens (Gallus Gallus Domesticus). Applied Animal Behavior Science, v. 64, p. 57- 69, 1999.

LUNDBERG, A.S.; KEELING, L.J. Social effects on dustbathing behaviour in laying hens: using video images to investigate effect of rank. Applied Animal Behavior Science, v. 81, p. 43-57, 2003.

MACARI, M. Água de beber na dose certa. Aves \& Ovos, v. 9, n. 6, p. 40-80, 1995.

MASHALY, M.M.; HENDRICKS, G.L.; KALAMA, M.A.; GEHAD, A.E.; ABBAS, A.O.; PATTERSON, P.H. Effect of heat stress on production parameters and immune responses of commercial laying hens. Poultry Science, v. 83, p. 889-894, 2004.

MAUDLIN, J.M. Applications of behavior to poultry management. Poultry Science, v. 71, p. 634-642, 1992.

MATARAZZO, S.V. Eficiência do sistema de resfriamento adiabático evaporativo em confinamento do tipo freestall para vacas em lactação. Piracicaba - SP, 2004. Tese (Doutorado) - Escola Superior de Agricultura Luiz de Queiroz, Universidade de São Paulo.

MILLER, P.C.; SUNDE, M.L. The effects of precise constant and ciclic environments on shell quality and other lay performance factors with leghorn pullets. Poultry Science, v. 54, p. 36-46, 1975. 
NÄÄS, I.A. Aspectos físicos da construção no controle térmico do ambiente das instalações. In: CONFERÊNCIA APINCO DE CIÊNCIA E TECNOLOGIA AVÍCOLA. Santos, SP, 1994. Anais, p - 167..

NAKANO, M. Problemas da avicultura no verão. Avicultura Industrial, Seção de Doenças das Aves. Fevereiro, 1979.

NICOL, C.J.; LINDBERG, A.C.; PHILIPS, A.J.; POPE, S.J.; WILKINS, L.J. The effects of rearing experience on the development of feather pecking and of substrat preferences in laying hens. In: INTERN. CONG. ISAE, 34, Florianópolis - SC, Brazil. 2000. Proceedings, p. 17-20.

ÓDEN, K. Fear and agression in large floks of laiyng hens. Skara, 2003. Thesis (Ph.D.) - Swedish University of Agricultural Sciences, $46 \mathrm{p}$.

OLIVEIRA, B. L.; VALLE, R. H. P.; BRESSAN, M. C.; CARVALHO, E. P. Tecnologia de ovos. Lavras: UFLA/FAEPE, 2001. 75 p.

OLSSON, I.A.S.; KEELING, L.J. Night time roosting in laying hens and the effect of thwarting access to perches. Applied Animal Behavior Science, v. 68, p. 243-256, 2000.

PADRON, M.N. Salmonella Typhimurium Penetration through the eggshell of hatching eggs. Avian Desease, n. 34, p. 463-465, 1990.

PAGANINI, F.J. Aspectos microbiológicos na reutilização da cama de frangos de corte. Avicultura Industrial, n. 1074, p. 76-77, 1999.

PAGANINI, F.J. Reutilização de cama na produção de frangos de corte: porque, quando e como fazer. In: CONFERÊNCIA APINCO DE CIÊNCIA E TECNOLOGIA AVÍCOLAS, Anais, 2002. 
PANDORFI, H. Avaliação do comportamento de leitões em diferentes sistemas de aquecimento por meio da análise de imagem e identificação eletrônica. Piracicaba - SP, 2002. Dissertação (Mestrado) - Escola Superior de Agricultura Luiz de Queiroz, Universidade de São Paulo, 108 p.

PARDI, H.S. Influencia da comercialização na qualidade dos ovos de consumo. Rio de Janeiro, 1977. Dissertação (Mestrado) - Universidade Federal Fluminense, 73 p.

PAYNE, G.C. Environmental temperature and egg production - The physiology of the domestic fowl, Edinburgh, 1967, p. 235-241.

PEEBLES, E.D.; BRAKE, J. Relationship of eggshell porosity to stage of embryonic development in broiler breeders. Poultry Science, v. 64, p. 2388-2391, 1985.

PEEBLES, E.D.; McDANIEL, C.D. A practical manual for understanding the shell structure of broiler hatching eggs and measurementes of their quality. Mississipi: State University, 2004. 16 p. (Bulletin, 1139).

PEREIRA, A.M. Stress calórico em poedeiras comerciais. In: SEMINÁRIO DE POSTURA COMERCIAL. Campinas: GUABI, 1991. p. 133-146.

PERISSINOTO, M. Avaliação da eficiência produtiva e energética de sistemas de climatização em galpões tipo freestall para confinamento de gado leiteiro. Piracicaba - SP, 2003. Dissertação (Mestrado) - Escola Superior de Agricultura Luiz de Queiroz, Universidade de São Paulo. 141 p.

PETHERICK, J.C.; SEAWRIGHT, E.; WADDINGTON, D. Influence of quantity of litter on nest box selection and nesting behaviour of domestic hens. British Poultry Science, n. 34, p. 857-872, 1994.

PETHERICK, J.C.; SEAWRIGHT, E.; WADDINGTON, D.; DUNCAN, I.J.H.; MURPHY, L.B. The role of perception in the causation of dustbathing behaviour in domestic fowl. Animal Behaviour, n. 49, p. 1521-1530, 1995. 
PULICI, C. Liberdade, igualdade e fraternidade, tendências mundiais pelos produtos orgânicos. Avicultura Industrial, p. 46-48, 2001.

RAUCH, H.W. The future housing of laying hens in cages. Berichte Uber Landwirtschaft, v. 79, n. 1, p. 140-159, 2001.

RODRIGUESI, P.C. Contribuição ao estudo da conversão de ovos de casca branca e vermelha. Piracicaba - SP, 1975. Dissertação (Mestrado) - Escola Superior de Agricultura Luiz de Queiroz, Universidade de São Paulo.

ROLAND, D.A. Maintain egg shell quality with "five step program". Poultry Digest, v. 40, n. 477 , p. 584-588, 1981.

RUDKIN, C.; STEWART, G.D. Behaviour of hens in cages - A pilot study using video tapes. A Report for the Rural Industries Researsh and Development Corporation (RIRDC), v. 40, n. 477, p. 102, 2003.

RUTZ, F. Aspectos fisiológicos que regulam o conforto térmico das aves. In: CONFERÊNCIA APINCO DE CIÊNCIA E TECNOLOGIA AVÍCOLAS, Santos - SP, 1994. p. 99-110.

SALES, M.N.G., GARCIA, R.A.M., PINHEIRO MACHADO, F.L. C., PADILHA, J.C.F., SILVEIRA, T.D., DINON, P.S.L. Isa Brown and Native Brazilian Chicks raised on pasture display similar behavior. In: Intern. Congress of the ISAE, 34. Florianópolis, Brazil, 2000. Proceedings.

SALTER, E.A.; PETERSEN, C.F. The effect of egg shell quality on penetration by various Salmonellae. Poultry Science, v. 53, p. 2159-2162, 1974.

SCOTT, T.A.; BELNAVE, D. Comparison between concentrated complete diets and self-selection for feeding sexually-maturing pullets at hot and cold temperatures. British Poultry Science, n. 29, p. 613-625, 1988. 
SERGEANT, D.; BOYLE, R.; FORBES, M. Computer visual tracking of poultry. Computers and Electronics in Agriculture, n. 21, p. 1-18, 1998.

SAS INSTITUTE. Statistical Analysis System (Software). Cary, 1998. 620p.

SEVEGNANI, K.B.; MACARI, M.; NÄÄS, I.A.; MOURA, D.J.; SILVA, I.J.O. Variação das perdas de Calor sensível e latente de frangos de corte aos 35 dias, submetidos à ventilação forçada. Revista Brasileira de Ciência Avícola, supl. 3, p. 2, 2001a.

SEVEGNANI, K.B.; MACARI, M.; NÄÄS, I.A.; MOURA, D.J.; SILVA, I.J.O. Variação da temperatura média corporal de frangos de corte em terminação, submetidos às temperaturas de 24 e $32^{\circ} \mathrm{C}$, em câmara climática. Revista Brasileira de Ciência Avícola, supl. 3, P. 58, 2001 b.

SILVA, I.J.O. Ambiência na produção de aves em clima tropical. Piracicaba, 2001. v. 2 , p. $150-204$.

SILVA, I.J.O., NÄÄS, I. A., BUCKLIN, R. A. Evaluation of egg production housing in hot climate. ATLANTA:ASAE, 1994. p. 1-8. (ASAE PAPER, 94.4567).

SILVA, I.J.O., Desenvolvimento de modelos matemáticos para avaliar a influência das condições ambientais na produção industrial de ovos. Campinas, 1998. Tese (Doutorado) - Feagri, Universidade de Campinas. $145 \mathrm{p}$.

SILVA, P.L. Influência do manejo na qualidade da casca dos ovos de reprodutoras pesadas. In: CONFERÊNCIA APINCO DE CIÊNCIA E TECNOLOGIA AVÍCOLAS, Anais, 1994.

SILVERSIDES, F.G.; TWIZEYIMANA, F.; VILLENEUVE, P. A Study relating to the validity of the haugh unit correction for egg weight in fresh eggs. Poultry Science, v. 72, p. 760-764, 1993. 
SINGER, P. Animal Liberation. 1991. p - 97,118.

http://www.vegetarianismo.com.br/artigos/o-problema-dos-ovos.html. (28 ago. 2002).

SMITH, C.V.A Quantitative relationship between environment, comfort and animal productivity. Agricultural Meteorology, v. 1, p. 249-270, 1964.

SOUZA, E.R.N.; CARVALHO, E.P.; DIONIZIO, F.L. Estudo da presença de Salmonella $s p$ em poedeiras submetidas a muda forçada. Ciência Agrotécnica, Lavras, v. 26, n. 1, p. 140-147, 2002.

SOUZA, H.B.A.; SOUZA, P.A.; BROGNONI, E.; ROCHA, O.E. Influência da idade sobre a qualidade dos ovos. Cientifica, São Paulo, v. 22, n. 2, p. 217-226, 1994.

STURKIE, P.D. Fisiologia aviaria, Zaragoza. Ed. Acribia, 1967. 607p.

THOM, E.C. The discomfort index, v. 12, n. 1, p. 57-60, 1959.

VAN BORELL, E. Neuroendocrine integration of stress and significance of stress for the performance fo farm animals. Applied Animal Behavior Science, v. 44, p. 219-227, 1995.

VESTERGAARD, K. Dustbathing in the domestic fowl - Diurnal rhythm and dust deprivation. Applied Animal Ethology, n. 8, p. 487-495, 1982.

VOISEY, P.W.; HUNT, J.R. Messurements of eggshell strength. Textile Studies. n. 5, p. 135-182, 1974.

WALL, H.; TAUSONL, R. Egg quality in furnished cages for laying hens - effects of crack reduction measures and hybrid. Poultry Science, v. 81, p. 340-348, 2002.

WARREN, D.C.; SCHNEPEL, L.R. The Effect of air temperatures on egg shell thickness in the fowl. Poultry Science, v. 19, p. 67-72, 1940. 
WOOD-GUSH, D.G.M. Strain differences in response to sub-optimal stimuli in the fowl. Animal Behaviour, v.20, p. 72-76, 1972.

WOOD-GUSH, D.G.M. Nest construction by the domestic hen: some comparative and fisiological considerations. Neural and Endocrine Aspects of Behaviour in Birds. Elsevier:Amsterdam, 1975. p. 35-49.

XIN, H., SHAO, J. Real-Time assessment of swine thermal comfort by computer vision. In: Proceedings of WORLD CONGRESS OF COMPUTERS IN AGRICULTURE AND NATURAL RESOURCES. 2; Foz do Iguaçu, Brazil, 2002. Proceedings. Foz do Iguaçu: ASAE, 2002. p. 362-369.

XIN, J.; BECK, H.; HALSEY, L.; FLETCHER, J.; ZAZUETA, F. Using digital cameras and the internet to identify plant insect and disease problems. In: INTERNATIONAL CONFERENCE ON COMPUTERS IN AGRICULTURE, 17; Orlando, 1998. Proceedings. Orlando: ASAE, 1998. p. 327-329.

YAHAV, S.; SHINDER, D.; RAZPAKOVSKI, V.; RUSAL, M.; BAR, A. Lack of response of laying hens to relative humidity at high ambient temperature. British Poultry Science, n. 41 , p. 660-663, 2000. 